\title{
RESISTÊNCIA À FRATURA DE DENTES QUE RECEBERAM RESTAURAÇÕES ADESIVAS DE RESINA COMPOSTA E PORCELANA
}

\author{
Paulo Henrique Perlatti D’Alpino
}

Dissertação apresentada à Faculdade de Odontologia de Bauru, da Universidade de São Paulo, como parte dos requisitos para obtenção do título de Mestre em Odontologia, Área de Dentística.

(Edição Revisada) 


\title{
RESISTÊNCIA À FRATURA DE DENTES QUE RECEBERAM RESTAURAÇÕES ADESIVAS DE RESINA COMPOSTA E PORCELANA
}

\section{Paulo Henrique Perlatti D’Alpino}

\author{
Dissertação apresentada à Faculdade de \\ Odontologia de Bauru, da Universidade \\ de São Paulo, como parte dos requisitos \\ para obtenção do título de Mestre em \\ Odontologia, Área de Dentística. \\ (Edição Revisada)
}

Orientador:

Prof. Dr. Carlos Eduardo Francischone 
D'Alpino, Paulo Henrique Perlatti

D169r Resistência à fratura de dentes que receberam restaurações adesivas de resina composta e porcelana / Paulo Henrique Perlatti D’Alpino. - Bauru, 2000.

161p. : il. ; $30 \mathrm{~cm}$.

Dissertação. ( Mestrado ) - - Faculdade de Odontologia de Bauru. USP.

Orientador : Prof. Dr. Carlos Eduardo Francischone

Autorizo, exclusivamente para fins acadêmicos e científicos, a reprodução total ou parcial desta dissertação, por processos fotocopiadores e outros meios eletrônicos.

Assinatura do autor : 


\section{PAULO HENRIQUE PERLATTI D`ALPINO}

30 de Junho de 1966

Jaú - SP

1988-1991

$1999-2000$

Associações
Nascimento

Curso de Odontologia - Faculdade de Odontologia de Bauru - USP

Curso de Pós-Graduação em

Dentística ao nível de Mestrado, na Faculdade de Odontologia de Bauru, USP.

APCD - Associação Paulista de Cirurgiões Dentistas.

SBOE - Sociedade Brasileira de Odontologia Estética.

GBPD - Grupo Brasileiro de Professores de Dentística.

$I A D R$ - International Association For Dental Research.

$S B P Q o$ - Sociedade Brasileira de Pesquisa Odontológica. 


\title{
Dedicatória
}

\author{
A Deus, \\ por me conceder a vida; \\ por me dar luz e proteção; \\ por me dar inspiração e coragem; \\ por colher o fruto....obrigado Senhor.
}

Ao meu querido pai, Armando,

pelo exemplo de bondade, alegria e amor ao próximo, que mesmo não estando presente entre nós, é uma lembrança viva e constante em nossos corações;

À minha querida mãe, Neusa, mulher de coragem, mãe dedicada, senhora de virtudes tão próprias dos grandes vencedores, exemplo de ser humano que admiro e me inspiro.

Dedico este trabalho 


\section{Agradecimentos Especiais}

Ao meu orientador, Prof. Dr. Carlos Eduardo Francischone, pela confiança depositada na minha pessoa e no meu trabalho, e pelo incentivo após tantos anos afastado da vida acadêmica;

À minha irmã, Vera Helena, pelo apoio e atenção, e pela dedicação à família, base de toda nossa formação;

Ao meu irmão, Carlos Alberto (Nenê) e minha cunhada, Luciane (Sani), pelas palavras de incentivo e pelo apoio naqueles tempos difíceis;

À minha namorada, Ana Sílvia Moretto, pelo incentivo, carinho, compreensão e companheirismo que mereci por todo este tempo;

Aos meus colegas do mestrado, Amanda, Bárbara, Celiane, Daniela, Fábio, Fernanda, Júlio César, Lawrence e Linda, pelo espírito de grupo e pela amizade e carinho com que me receberam,

Minha eterna gratidão 
Agradeço Ainda...

À Prof. Dra. Maria Fidela de Lima Navarro, pela incansável dedicação ao ensino e à pesquisa, digna representante desta Faculdade;

Aos professores da Disciplina de Dentística Restauradora, pela dedicação ao ensino e estímulo ao nosso aprendizado;

Aos funcionários do Departamento de Dentística, pela convivência, amizade e colaboração para conosco;

À FAPESP, pela colaboração decisiva, sem o qual este trabalho não poderia ser realizado, e à funcionária Vera Regina Casari Boccato, representante na FOB;

Aos funcionários do Serviço de Biblioteca e Documentação da Faculdade de Odontologia de Bauru, importantes colaboradores dos alunos e professores;

Ao funcionário Reivanildo Francisco Viana, do Departamento de Prótese, pela colaboração e atenção para a realização dos testes de compressão;

Aos Protéticos Hilton Riquieri e Odair Caldeira, pela dedicação e presteza na realização das restaurações indiretas;

À Valéria Cristina Trindade Ferraz, funcionária do Serviço de Biblioteca e Documentação, pela revisão deste trabalho;

Ao Prof. Dr. José Mauro Granjeiro, pela realização do histograma;

Ao Prof. José Roberto Lauris, pelos esclarecimentos da análise estatística;

Aos funcionários da reprografia, Salvador e Joice, pela colaboração e atenção dispensada;

Ao funcionário Rubens Kazuo Kato, pela atenção e cuidado na realização da capa e tratamento das fotos deste trabalho;

Ao Prof. Sebastião A. da Silva Neto (Prof. Sebah), pela correção do vernáculo; 
Aos colegas Danilo Montovanelli Júnior, Milton Sciúffa, Róger Simões de Castro, Lawrence G. Lopes, Júlio C. F. Almeida, Dra. Maria Teresa A. Bastos, Lúcia C. G. Pereira, pela colaboração na obtenção dos dentes pré-molares;

À Comissão de Pós-Graduação da FOB, na pessoa do Prof. Dr. Luiz Fernando Pegoraro, pelo empenho contínuo para com ensino e a pesquisa;

Aos funcionários da Secretaria da Pós-Graduação pela atenção e colaboração para com os pós-graduandos;

Às funcionárias da Clínica de Pós-Graduação, Ana e Cleusa, pela dedicação e paciência com os alunos no transcorrer da clínica;

À Faculdade de Odontologia de Bauru - USP, na pessoa de seu Diretor, Prof. Aymar Pavarini, pela possibilidade da realização de meus estudos e contínuo esforço pela manutenção da integridade desta instituição;

Aos meus familiares, meu irmão Paulo Sérgio, Tios e Primos, incentivando e apoiando em todos os momentos;

Aos amigos Maria de Fátima de Oliveira, Loreta de Oliveira e Carlos José Fini, pela colaboração, estímulo e amizade;

Ao amigo Rodolfo Mauro Nunhez, pela colaboração no artigo para o American Journal of Dentistry;

Ao Dr. Abdala Atique, Diretor Técnico de Serviço do N.P.A. D. - 4 Jaú, e à Direção Regional - D.I.R X Bauru, da Secretaria de Saúde do Estado de São Paulo, pela colaboração na obtenção da licença como funcionário do S.U.S.;

A todos que, embora não nominalmente citados, colaboraram direta ou indiretamente durante todo o transcorrer do Mestrado e principalmente na realização deste trabalho.

\section{O meu muito obrigado}




\section{SUMÁRIO}

LISTA DE ABREVIATURAS E SÍMBOLOS.........................................

LISTA DE FIGURAS.........................................................................

LISTA DE TABELAS...................................................................

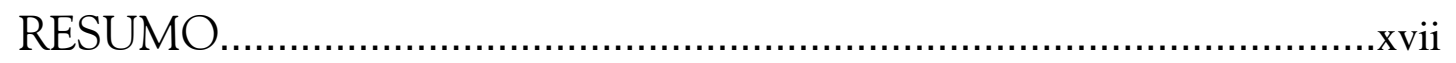

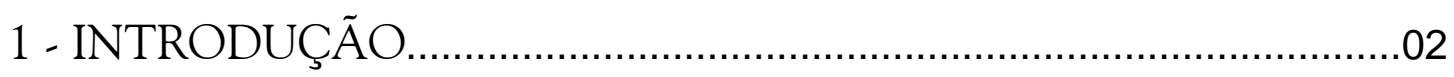

2 - REVISÃO DA LITERATURA ......................................................12

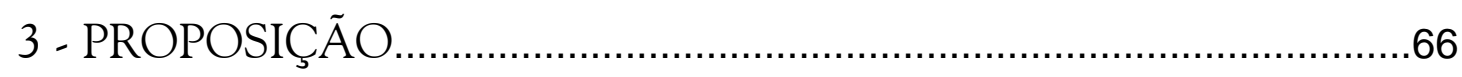

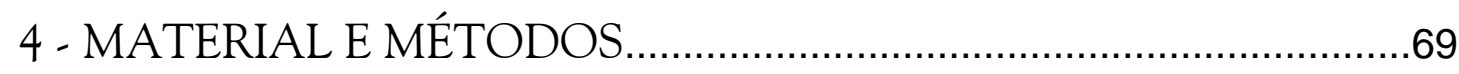

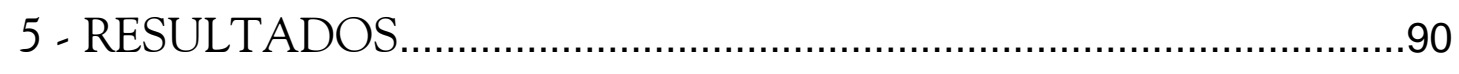

6 - DISCUSSÃO

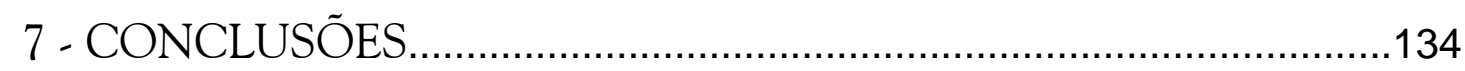

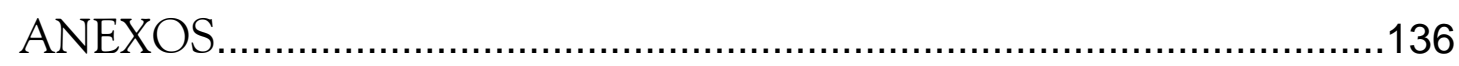

REFERÊNCIAS BIBLIOGRÁFICAS....................................................144

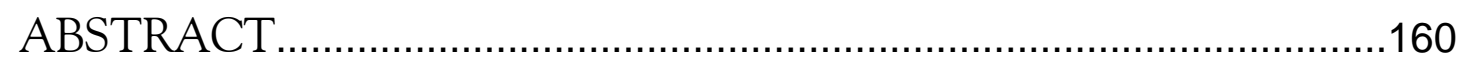




\section{LISTA DE ABREVIATURAS E SÍMBOLOS}

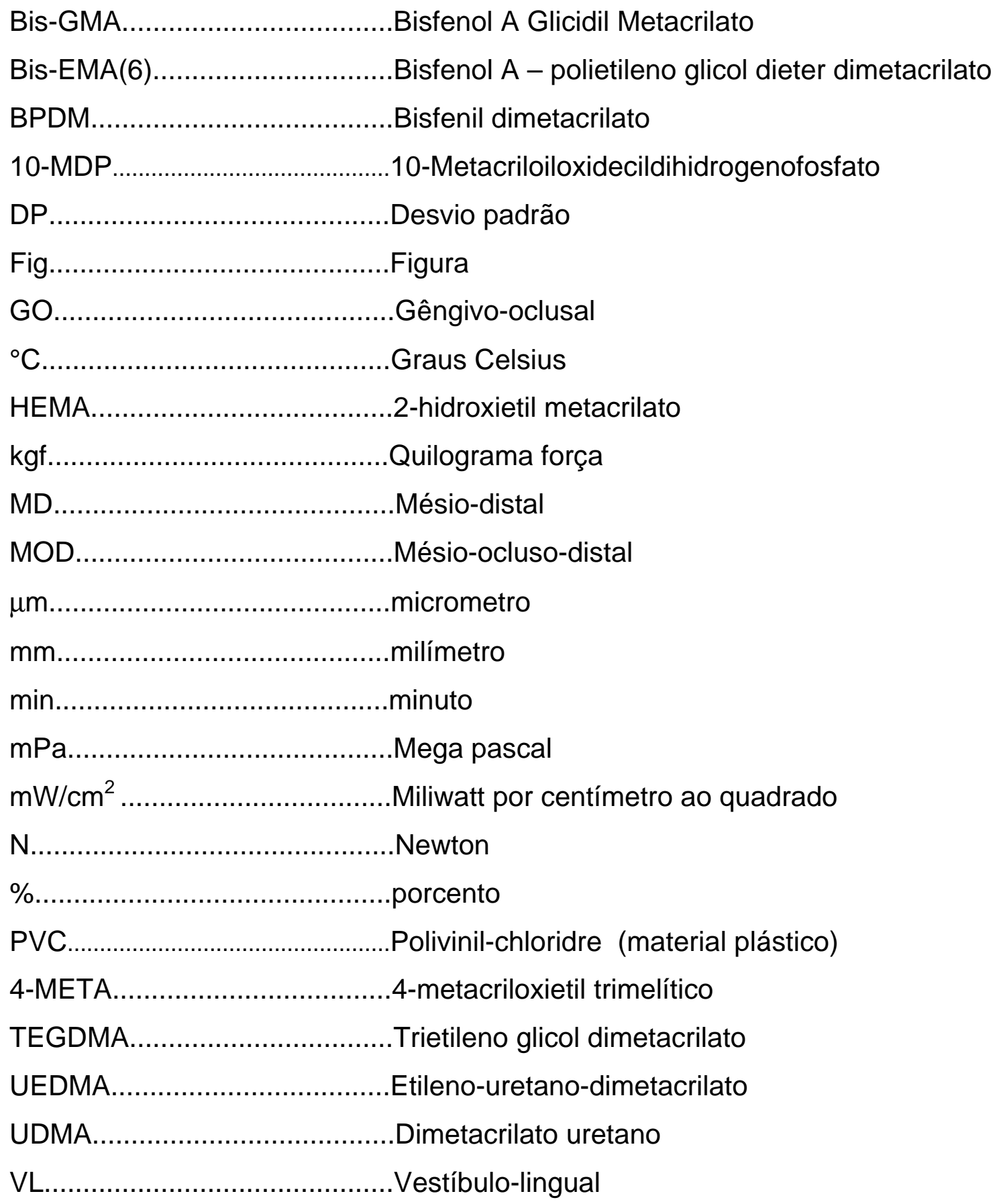




\section{LISTA DE FIGURAS}

FIGURA 1 - Preparos cavitários classe II MOD, com aberturas de $1 / 4$, $1 / 3$ e 1/2 da distância

intercuspídea $^{74}$

FIGURA 2 - Vista oclusal do preparo classe I (O) e do preparo classe II (MOD) realizados em dentes pré-molares ${ }^{63}$

FIGURA 3 - Típica fratura de cúspide $^{8}$

FIGURA 4 - Interpenetração de adesivo na intimidade dos túbulos.

Microscopia após a descalcificação da dentina ${ }^{79}$

FIGURA 5 - Preparos cavitários com diferentes dimensões realizados nos pré- molares ${ }^{9}$

FIGURA 6 - Dente hígido $(\mathrm{A})$

Lesão cariosa oclusal (B)

Cárie proximal $(C)^{81}$

FIGURA 7 - Cárie proximal com envolvimento da crista marginal (D)

Remoção do teto da câmara $(E)$

Remoção do teto e R.M.F. com proteção de cúspide $(\mathrm{F})^{81}$

FIGURA 8 - Curvas de tensão

Dentes hígidos $(A)$

Dente com restaurações não adesivas (B)

Dente com restaurações

adesivas (C) ${ }^{77}$ 
FIGURA 9 - Dente pré-molar que

recebeu apenas

preparo cavitário, sob

ação de uma carga de

compressão com um

cilindro de aço ${ }^{69}$......

FIGURA 10 - Teste de resistência à fratura através da ação de uma barra de aço, aplicada às vertentes de cúspides ${ }^{104}$

FIGURA 11 - Teste de carregamento axial, para avaliar-se a flexão de cúspide ${ }^{58}$

FIGURA 12 - Preparo cavitário realizado nos pré-molares, sendo que A corresponde a $1 / 3$ de $B$ e $C$ corresponde a $1 / 3$ de $D^{59}$

FIGURA 13 - Preparo cavitário reduzido com $1 / 3$ da distância intercuspídea ${ }^{98}$

FIGURA 14 - Preparo cavitário amplo com $1 / 2$ da dimensão vestíbulolingual $^{98}$

FIGURA 15 - Inserção da resina composta pela técnica do único incremento por caixa $^{117}$

FIGURA 16 - Inserção da resina composta pela técnica incremental ${ }^{117}$

FIGURA 17 - Dimensões dos preparos cavitários realizados ${ }^{92}$

FIGURA 18 - Teste de compressão axial realizado através de duas barras metálicas ${ }^{57}$

FIGURA 19 - Dimensões dos preparos $^{32}$ 
FIGURA 20 - Profundidade e extensão dos preparos $^{32}$

FIGURA 21 - Flexão das cúspides em direções opostas ${ }^{67}$

FIGURA 22 - As cúspides defletem na mesma direção ${ }^{67}$

FIGURA 23 - Comparação entre a deflexão de um simples "cantilever" e um preparo classe II MOD ${ }^{54}$

FIGURA 24 - Padrões de fratura descritos de acordo com o grau de severidade $^{21}$

FIGURA 25 - Dimensões dos preparos $^{83}$

FIGURA 26 - Profundidade e extensão dos preparos $^{83}$

FIGURA 27 - Processo de inclusão dos dentes 70

FIGURA 28 - Preparo cavitário para restaurações diretas Vista proximal ....... .73

FIGURA 29 - Preparo cavitário para restaurações diretas Vista oclusal............................73

FIGURA 30 - Desenho esquemático do preparo para restaurações diretas........................74

FIGURA 31 - Preparo cavitário para restaurações indiretas Vista proximal........................76

FIGURA 32 - Preparo cavitário para restaurações indiretas Vista oclusal..........................76

FIGURA 33 - Desenho esquemático do preparo para restaurações indiretas......................77

FIGURA 34 - Desenho esquemático da técnica de inserção da resina direta......................79

FIGURA 35 - Aparato utilizado para padronização da pressão de cimentação....................83

FIGURA 36 - Desenho esquemático do teste de compressão...........................................86 
FIGURA 37 - Teste de compressão axial.

FIGURA 38 - Gráfico representativo das médias dos valores obtidos. .91

FIGURA 39 - Histograma do tipo Box-and-Whisker Plot. .92

FIGURA 40 - Padrões de fratura apresentados pelos corpos de prova restaurados com restaurações diretas de Filtek Z250.

FIGURA 41 - Padrões de fratura apresentados pelos corpos de prova restaurados com restaurações indiretas de resina composta Artglass.

FIGURA 42 - Padrões de fratura apresentados pelos corpos de prova restaurados com restaurações indiretas de resina composta Targis

FIGURA 43 - Padrões de fratura apresentados pelos corpos de prova restaurados com restaurações indiretas de porcelana IPS Empress. 


\section{LISTA DE TABELAS}

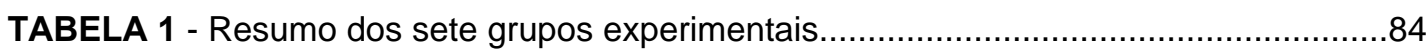

TABELA 2 - Análise descritiva da estatística básica (Valores em kgf)...............................90

TABELA 3 - Resultado do teste de análise de variância

Um critério de classificação - Modelo Fixo.......................................................93

TABELA 4 - Comparações Individuais - Teste de Tukey ..................................................94

TABELA 5 - Padrão de fratura apresentado pelos grupos restaurados...............................95

TABELA 6 - Quadro comparativo dos materiais restauradores.......................................128 
RESUMO 


\section{RESUMO}

Avaliou-se a resistência à fratura de dentes pré-molares superiores que receberam diferentes preparos cavitários (classe II-MOD) e restaurações diretas e indiretas de resina composta e restaurações indiretas de porcelana. Cinqüenta e seis dentes recém extraídos, hígidos, foram selecionados e divididos em 7 grupos: Grupo 1- hígidos, controle, não recebeu qualquer tratamento; Grupo 2- preparo cavitário com broca carbide n.․ 245, produzindo cavidades retentivas, com ângulos internos arredondados, profundidade de $2 \mathrm{~mm}$, abertura de istmo de metade da distância intercuspídea, caixa proximal com parede axial de $2 \mathrm{~mm}$ de extensão e 1,5 mm de profundidade, abertura de metade da dimensão vestíbulo-lingual, não sendo restaurado; Grupo 3 - recebeu somente preparo cavitário com ponta diamantada n.ำ 2136, produzindo cavidades com paredes divergentes para oclusal, ângulos internos arredondados, com as mesmas dimensões do preparo anterior, não sendo restaurado; Grupo 4 - recebeu o mesmo preparo que o grupo 2 e restaurou-se com resina composta aplicada na forma direta (Single Bond - 3M/ Z-250 - 3M); Grupo 5 recebeu o mesmo preparo do grupo 3 e restaurou-se com resina indireta (Single Bond 3M/ Rely X-3M/ Artglass-Kulzer); Grupo 6 - recebeu o mesmo preparo que o grupo 3, sendo restaurado com resina composta indireta (Single Bond 3M/ Rely X3M/ Targis- Ivoclar); Grupo 7 - mesmo preparo que o grupo 3, restaurado com 
restaurações indiretas de porcelana (Single Bond 3M; Rely X- 3M/ IPS Empress Ivoclar). Submeteu-se os corpos de prova a testes de compressão axial, com um cilindro de aço (8 mm de diâmetro), acoplado a uma máquina de ensaios universal (Kratos), a uma velocidade de $0,5 \mathrm{~mm} / \mathrm{min}$, até que houvesse fratura de cúspide. Os valores obtidos foram os seguintes (em kgf): Grupo 1- 193,93 $\pm 24,46$; Grupo 2108,56 \pm 21,39; Grupo 3- 95,43 \pm 17,73; Grupo 4- 147,65 \pm 32,63; Grupo 5- 184,15 \pm 56,49; Grupo 6- 183,81 \pm 31,95; Grupo 7- 181,12 \pm 40,49. Observou-se que os preparos cavitários reduziram significantemente a resistência dos dentes; não houve diferença significante na resistência dos dentes quando se comparou os diferentes tipos de preparo cavitário; os materiais restauradores contribuíram para que esses valores aumentassem, não se observando diferença estatística entre os grupos 4, 5, 6 e 7 e o grupo controle; houve um aumento significante na resistência quando se comparou os grupos 5, 6 e 7 (restaurações indiretas) em relação ao grupo 3 (preparado e não restaurado), o mesmo não sendo observado com o grupo 4 (restauração direta) em relação ao grupo 2 (preparado e não restaurado). 
INTRODUÇÃO 


\section{1 - INTRODUÇÃO}

Levando-se em conta a prevalência de cárie na população, é freqüente a ocorrência de fraturas coronárias, visto que pode haver um sério comprometimento da estrutura dentária quando a doença se instalou há algum tempo. Esse tipo de fratura ocorre especialmente em dentes pré-molares, já que o contorno natural dos dentes posteriores, e em especial neste grupo de dentes, faz com que haja uma tendência em separar as cúspides vestibular e lingual (ou palatina), quando submetidas a esforços oclusais ${ }^{56}$. Apesar de nos dentes hígidos raramente ocorrerem fraturas, tais dentes são enfraquecidos por toda sorte de preparos que são realizados, visto que há um efeito de se criarem cúspides alongadas pela remoção do remanescente dentário, para adequação da forma de contorno interna e externa ${ }^{74}$. Os preparos cavitários realizados nestes dentes, faz com que as cúspides fiquem delgadas, favorecendo à deflexão das mesmas ${ }^{57}$, principalmente nos superiores, deflexão esta que é proporcional à força mastigatória e ao comprimento da cúspide ${ }^{54}$. A conseqüência natural dos tratamentos é a continuada substituição de restaurações, sendo que preparos iniciais pouco conservativos, seguidos por preparos adicionais, faz com que haja um maior aprofundamento da parede pulpar, que leva ao aumento da altura das cúspides. Além disso, há um consenso na literatura de que a resistência do remanescente é tanto menor quanto maior a quantidade de tecido dentário removido ${ }^{74,81,96}$. As superfícies dessas cúspides enfraquecidas com ou sem a 
"ponte dentinária" 56 , se não protegidas devidamente, serão submetidas a esforços que tendem a flexioná-las na união com a parede pulpar do preparo, sendo esta região a mais crítica, onde se concentra o maior estresse. BELL; SMITH; DE PONT ${ }^{8}$, em 1982, verificaram que, 92\% dos casos de fratura de dentes com preparos MOD restaurados com amálgama apresentaram o mesmo padrão, sendo que a linha de fratura caminhou para fora e para baixo, formando um ângulo de 40 a $50^{\circ}$ a partir do assoalho da cavidade, em direção à margem cervical. Estes casos de fraturas são particularmente mais freqüentes em dentes despolpados visto que há um enfraquecimento pela maior remoção de tecido e pela degradação da matriz orgânica da dentina ${ }^{7}$. Enquanto a fratura pode não ocorrer, a deflexão faz com que haja uma abertura na interface denterestauração, que leva à microinfiltração e conseqüente recorrência de cárie $^{74}$. Clinicamente, as forças mastigatórias são de relativa magnitude, sendo aplicadas através de um longo período de tempo, variando em intensidade, velocidade e direção de aplicação ${ }^{33}$, que contribuem com diferentes padrões de fratura.

O enfraquecimento dos dentes em decorrência da realização de preparos MOD e a ação dos materiais restauradores no restabelecimento da resistência dos tecidos dentários remanescentes têm sido estudado experimentalmente por diversos autores desde 1956, incluindo trabalhos que se tornaram clássicos na literatura odontológica como os de $\operatorname{VALE}^{110}$, 1956, MONDELLI et al. ${ }^{74}$, 1980, LARSON; DOUGLAS; GEISTFELD ${ }^{63}, 1981$, além de importantes trabalhos mais recentes como os de BURKE; WILSON; WATTS ${ }^{21}$, 1993, além de BRUNTON et al. $^{11}, 1999$, entre outros. A maioria destes estudos tem em comum a utilização de sistemas experimentais destrutivos, fraturando os dentes através da aplicação de 
uma carga axial, com a utilização de uma esfera ou cilindro de aço, em contato com a inclinação das vertentes de cúspide, tendo como controle dentes hígidos, e comparando os resultados com a média obtida pelos grupos de dentes que receberam uma variedade de preparos cavitários.

Embora os estudos in vitro não sejam uma reprodução real de uma típica força de mastigação, eles representam uma importante fonte de informação. Os testes de compressão, nos quais se aplica uma força até que ocorra a fratura definitiva dos corpos de prova, são a metodologia mais aplicada para comparar a resistência à fratura de dentes que receberam variados materiais restauradores, ou até mesmo, da própria restauração $8,9,37,46,57,58,59,62,63,66,74,76,81,88,96,98,110$. Inúmeros autores ${ }^{9,27,31,75,99,110}$ têm descrito uma série de preparos cavitários, visando à preservação de estrutura dentária, visto que, mesmo um preparo conservativo de classe I e posterior restauração típica intracoronária a amálgama, promove a diminuição da resistência do remanescente dentário ${ }^{81}$ e o efeito de cunha entre as cúspides ${ }^{44,99}$. Segundo MONDELLI et al. ${ }^{75}$, o preparo cavitário, sob o ponto de vista terapêutico, é o tratamento biomecânico da cárie e de outras lesões dos tecidos duros do dente, para que as estruturas remanescentes possam receber uma restauração que as proteja, seja resistente e previna reincidência de cárie. O sucesso dos procedimentos restauradores é dependente da compreensão das respostas dos tecidos dentários, principalmente em relação às forças mastigatórias, sendo que a instabilidade oclusal e as forças intensas da mastigação e deglutição são as principais causas de fratura em dentes hígidos e nos dentes com variados graus de comprometimento. Através de um estudo, in vivo, de HELKIMO; 
INGERVALL ${ }^{50}$ em 1978, observou-se que as forças mastigatórias em pacientes com dentição normal estão em torno de 19,5 a 81,7 kgf, verificando-se uma média de 48 kgf. A variação regional resultante das forças mastigatórias é crítica, pois, além de ser dependente da espessura do esmalte e da dentina, observou-se que estes tecidos, embora estejam organicamente unidos, respondem diferentemente às forças mastigatórias, e além disso, esta resposta varia dentro de um mesmo tecido, conforme a região solicitada ${ }^{47,91}$.

A freqüência de fratura de cúspide em pré-molares foi também estudada clinicamente, observando-se segundo CAVEL et al. ${ }^{26}$, uma maior ocorrência de fratura deste grupo de dentes na arcada superior, sendo a cúspide não funcional, ou seja, a vestibular, a mais freqüente, devido a fatores como a anatomia e inclinação, além do tipo de material restaurador presente. As cúspides não funcionais geralmente não possuem um alinhamento axial de forma que as forças oclusais terão um componente lateral maior, possibilitando uma maior ocorrência de flexão pela ação da força, que pode levar à fratura. A geração de tensão nos ângulos internos dos preparos por ação destas forças oclusais, deve ser minimizada pelo arredondamento dos mesmos, que possibilita uma maior estabilização das cúspides pela diminuição da deflexão e ainda uma menor remoção de estrutura dentária ${ }^{54}$. Para que as forças oclusais fossem mais uniformemente distribuídas, sugeriu-se a proteção sistemática das cúspides para cavidades muito extensas, nos casos em que as mesmas estivessem muito adelgaçadas $^{8,9,19,63,76,81,111}$.

A evolução que se verificou com o desenvolvimento de alguns materiais, no que se refere às propriedades físicas, químicas e biológicas, levou também a uma 
evolução na realização dos preparos cavitários clássicos, verificando-se o surgimento de novos conceitos de relevância. Com o aperfeiçoamento dos sistemas adesivos, possibilitou-se um incremento na resistência à fratura, visto que há um agente de união que promove adesão ao dente e aos materiais restauradores. Foi com base nestes dados que, em 1983, ZARDIACKAS; STONER ${ }^{120}$ introduziram o conceito de amálgama adesivo; e VARGA; MATSUMURA; MASUHARA ${ }^{112}$, em 1986, apresentaram um trabalho pioneiro que estudou a união do amálgama à estrutura dentária através de monômeros adesivos 4-META e 10-MDP. Apesar disso, alguns autores afirmaram que restaurações à amálgama não reforçam o remanescente $\mathrm{e}^{71,73,102} \mathrm{e}$, mesmo quando associadas aos adesivos dentinários, mostrou-se que não foi possível o reforço cuspídeo ${ }^{87,95}$. Os estudos comparativos entre amálgama e resina composta em relação à resistência à fratura foram inevitáveis, já que a resina composta passou a ser amplamente utilizada, com vantagens, pois, além da adesão à estrutura dentária, possibilita um menor desgaste do remanescente, visto que ele estaria restrito à remoção do tecido cariado e à conformação das paredes internas da cavidade $27,30,65,75,101$.

A utilização de materiais restauradores adesivos, em especial a resina composta na forma direta para dentes posteriores, foi sendo paulatinamente difundida, apesar das limitações como a sensibilidade da técnica, reduzida resistência ao desgaste e contração de polimerização, que faz com que haja falhas adesivas ou coesivas, que podem levar à microinfiltração, invasão bacteriana, sensibilidade pós-operatória e cárie recorrente ${ }^{17,36,106}$. Mas estes problemas têm sido contornados; e as resinas compostas, atualmente no 
mercado, tiveram suas propriedades mecânicas melhoradas, apresentando uma série de vantagens, como estética e, mais importante, a capacidade de união ao esmalte e à dentina, através dos sistemas adesivos. A resistência adesiva da resina composta ao esmalte previamente condicionado com ácido fosfórico é geralmente acima de $20 \mathrm{mPa} a^{60,107}$. A magnitude desta resistência adesiva possibilitou a utilização das resinas compostas que demonstraram grande eficácia na manutenção da integridade estrutural da coroa dentária, tendo um relativo potencial de reforço do remanescente $e^{6,30,33,57,69,71,73}$, reduzindo a flexão das cúspides $^{67,77,105}$, através da "esplintagem" das mesmas ${ }^{46,97}$. Especialmente, em se tratando de preparos cavitários classe II, MOD, em que o esmalte e a dentina residuais estão enfraquecidos, vai haver a diminuição da concentração de forças na base de cúspide, que é o local mais crítico, reduzindo a tendência de fratura da estrutura remanescente ${ }^{35,46,57,66,69,71,73,90,98}$.

Concomitante ao desenvolvimento dos sistemas adesivos, os sistemas restauradores diretos e indiretos de resina composta e sistemas restauradores indiretos de porcelana tiveram também os seus avanços, tendo a sua indicação para os dentes posteriores sido comprovada através de estudos clínicos e laboratoriais, com vantagens, como melhora das propriedades físicas e mecânicas, módulo de elasticidade e rigidez, adesão à estrutura dentária e excelente estética. Desta forma, uma vez realizada uma restauração adesiva, haveria um maior sinergismo entre dente e material restaurador capaz de absorver as forças mastigatórias, requisito básico necessário para a longevidade do elemento dental por um prolongado período de tempo ${ }^{54}$. 
A técnica de restauração com resinas compostas na forma indireta foi introduzida no início dos anos 80 , mais especialmente para a realização de "inlays" e "onlays" estéticas, e tem sua razão no intuito de melhorar as propriedades físicas e a performance clínica destes materiais, nos casos de cavidades em que estariam contra indicadas as resinas compostas na forma direta $^{108}$. Realizando-se as restaurações e complementando-se a polimerização indiretamente com calor, luz ou ainda sob pressão, há um maior grau de polimerização ${ }^{17,115}$, além da contração estar limitada à linha de cimentação ${ }^{14}$, reduzindo-se a formação de fendas marginais, e absorvendo a energia advinda das forças mastigatórias que causam flexão das cúspides ${ }^{29}$. Um estudo realizado por LOPES; LEITAO; DOUGLAS ${ }^{67}$, em 1991, para se verificar o papel das restaurações indiretas de resina composta no reforço cuspídeo, demonstrou que as mesmas contribuíram no restabelecimento de $97 \%$ da rigidez inicial, com a tendência à deflexão de cúspide em direção a um dos lados, ou seja, para vestibular ou para lingual, evidenciando-se a capacidade do material restaurador em manter as cúspides unidas, sem a tendência à separação das mesmas. Desta forma, através da utilização dos sistemas adesivos, possibilitou-se a viabilidade e longevidade de restaurações intracoronárias extensas, diretas ou indiretas, ampliando-se o limite da manutenção e o calçamento ou envolvimento das cúspides, que ocorrem nos preparos para restaurações extracoronárias.

A utilização da porcelana na tentativa da obtenção de um material restaurador que tivesse boas propriedades mecânicas, aliada à estética é muito antiga. Mas estas tentativas iniciais foram frustradas, devido à baixa resistência à fratura e à friabilidade que este material apresentava ${ }^{45}$. Associaram-se, então, 
propriedades das porcelanas (estética, alta resistência à compressão) com a dos metais (ductilidade e dureza), obtendo-se as restaurações metalocerâmicas ${ }^{38}$. Com o desenvolvimento das cerâmicas aluminizadas, possibilitou-se a substituição das estruturas metálicas, sendo que foram necessários ainda vários avanços para que este material tivesse as propriedades mecânicas melhoradas. Processos como a indução da cristalização com aumento da fase cristalina durante o processo da ceramização ${ }^{53}$, a correta observação dos princípios biomecânicos dos preparos, aliados à cimentação adesiva ${ }^{14}$ foram os maiores responsáveis pela maior resistência à compressão e fratura, melhor adaptação e selamento marginal obtidos por este material restaurador ${ }^{45}$.

Como se pode observar, há diversos materiais restauradores disponíveis no mercado, que, com o aprimoramento dos sistemas adesivos, viabilizaram a sua utilização, apesar da sensibilidade desta técnica. Dentre estas alternativas de materiais restauradores, torna-se importante 0 conhecimento de suas propriedades físicas e mecânicas, que aliados à técnica e à correta indicação, vão ser capazes de restabelecer a forma, função e a estética. Além disso, estes materiais devem possibilitar a manutenção da vitalidade do complexo dentinopulpar, ter retenção e estabilidade quando sob ação de esforços mastigatórios, além de apresentar selamento marginal, evitando-se assim a recorrência de cárie. Desta forma, o tratamento restaurador previne a fratura através de um reforço da estrutura do remanescente dentário, auxiliando na manutenção e longevidade do dente.

Sendo assim, propôs-se avaliar, in vitro, a resistência à fratura de dentes que receberam somente preparos cavitários diretos e indiretos, de dentes que 
receberam restaurações adesivas de resina composta e porcelana e ainda compará-los a um grupo de dentes hígidos que funcionou como controle. 
REVISÃO DA

LITERATURA 


\section{2 - REVISÃO DA LITERATURA}

Um dos maiores marcos na Odontologia foi a publicação do trabalho de BUONOCORE ${ }^{12}$, em 1955, em que avaliou o efeito do condicionamento ácido do esmalte. Este pesquisador submeteu amostras deste tecido dentário à ação do ácido fosfórico, com concentração de $85 \%$, durante 30 segundos, aplicando-se, em seguida, resina acrílica. Verificou-se que houve um aumento significativo da resistência de união entre o material restaurador e o tecido dentário, além da diminuição da microinfiltração marginal. Observou-se que o aumento na adesão ocorreu devido a uma maior superfície gerada para que houvesse a retenção do material restaurador, pois houve uma remoção da camada superficial, de forma que se criassem microrretenções mecânicas no interior do esmalte. Uma vez que houvesse uma união mais efetiva e duradoura entre o material restaurador e o esmalte, estaria eliminada a necessidade da utilização de formas de retenção e de resistência.

$V A L E^{110}$, em 1956, publicou um dos primeiros trabalhos investigativos sobre a influência da dimensão e o tipo de preparo cavitário na resistência à fratura de dentes. Este autor avaliou o efeito da largura vestíbulo-lingual em cavidades tipo MOD, confeccionadas em dentes pré-molares íntegros e aos pares, sendo que um deles servia como controle, sem qualquer tratamento. Pode-se verificar que, em cavidades com largura vestíbulo-lingual estreita, ou seja, com 1/4 do istmo na caixa oclusal, necessitavam uma carga igual à aplicada no grupo controle para que 
ocorresse a fratura. À medida que a largura vestíbulo-lingual aumentava para 1/3, a carga necessária para que os corpos de prova fraturassem era menor. Desta forma, enfatizou-se a necessidade da realização de preparos cavitários que fossem conservativos.

Uma grande revolução na odontologia restauradora e no campo dos materiais dentários ocorreu em 1963, quando $B O W E N^{10}$ introduziu a resina composta. Após várias pesquisas, o autor uniu a resina epóxica com resina acrílica, obtendo o Bisphenol Glicidil Metacrilato (BIS-GMA). Um componente da resina epóxica, o éter glicidil do bistenol $A$, reage com o metacrilato da resina acrílica, dando origem à chamada resina de Bowen, que nada mais é do que a parte orgânica da resina composta. Para incrementar as propriedades físicas e mecânicas deste material, o autor incorporou uma carga inorgânica, que se uniu à matriz orgânica através de um agente de união (silano).

Com o intuito de se estimar o reforço interno de estruturas de esmalte sem suporte, DENEHY; TORNEY ${ }^{30}$ em 1976, utilizaram resina composta autopolimerizável associada a um agente de união resinoso sem carga, através da união micromecânica após condicionamento ácido de esmalte (ácido fosfórico a $50 \%$, por 1 minuto). Utilizaram-se amostras de esmalte com suporte de dentina removido através de brocas esféricas, aplicou-se sobre estas amostras uma resina composta, sob duas condições distintas: em um grupo, foi utilizado condicionamento ácido do esmalte e aplicado um agente de união resinoso sem carga e, posteriormente, resina composta autopolimerizável; no outro grupo, as amostras de esmalte não receberam nenhum tipo de tratamento prévio à aplicação da resina composta. Em seguida, a interface entre o esmalte e a resina composta foi 
observada em microscopia eletrônica. No grupo que recebeu condicionamento ácido e aplicação de um agente de união foi observado um íntimo contato entre o esmalte e a resina, não havendo a ocorrência de fendas ou espaços. Diferentemente, observou-se no outro grupo um espaço, ou aberturas entre o esmalte e a resina. Sugeriu-se com base nestes achados, que se deve levar em consideração, nos casos de preparos de cavidades onde ocorra a presença de áreas de esmalte sem suporte, uma abordagem mais conservadora, em vez de partir para soluções mais radicais, como remoção deste esmalte e proteção sistemática de cúspides, utilizando técnicas adesivas, através de condicionamento ácido de esmalte, tanto na superfície externa do esmalte, quanto na face interna, no sentido de otimizar a união micromecânica e proporcionar reforço adequado destas áreas de esmalte enfraquecidas.

MONDELLI et al. ${ }^{74}$, em 1980, estudaram a resistência à fratura de cem dentes pré-molares superiores hígidos que receberam preparos cavitários, com três amplitudes baseadas na dimensão vestíbulo-lingual, e compararam os grupos entre si e com dentes hígidos que não receberam qualquer tratamento. Dividiu-se a amostra em dez grupos com dez exemplares em cada grupo, a saber:

controle - hígido, sem nenhum tipo de preparo cavitário;

classe I (O) - largura de istmo oclusal de 1/4, 1/3 e 1/2 da distância intercuspídea;

classe II (MO) - largura do istmo oclusal de 1/4, 1/3 e 1/2 da distância intercuspídea; classe II (MOD) - largura do istmo oclusal 1/4, 1/3 e 1/2 da distância intercuspídea (Figura 1); 


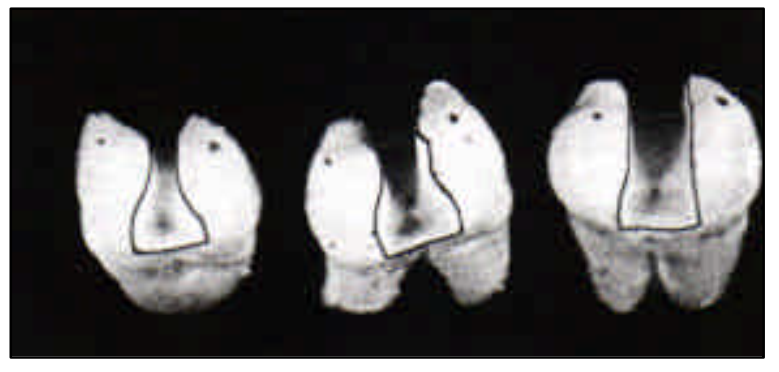

FIGURA 1 - Preparos cavitários classe II MOD, com aberturas de $1 / 4$, $1 / 3$ e $1 / 2$ da distância intercuspídea $^{74}$

Os preparos possuíam em comum paredes vestibular e lingual paralelas entre si, paredes proximais ligeiramente divergentes e com profundidade de $2,5 \mathrm{~mm}$. Submeteram-se todos os grupos a ensaio de carregamento axial em uma máquina de ensaios universal utilizando-se uma esfera de aço de 4,0 mm de diâmetro, em contato com as vertentes cuspídeas, vestibular e lingual, a uma velocidade de 0,5 $\mathrm{mm} / \mathrm{min}$. Através da análise dos resultados, verificou-se que independentemente do tipo de preparo cavitário, qual seja, classe I ou II, quanto menor a largura do istmo oclusal (1/4), maior a resistência do dente à fratura. Em relação às cavidades de classe II MO ou MOD, com istmo oclusal mais largo, com 1/3 ou 1/2 de largura, não houve diferença estatística significante de resistência à fratura, encontrando-se valores cerca de até $50 \%$ da resistência observada no grupo controle. Os autores puderam concluir que a largura do istmo é um fator significante na perda da resistência, sugerindo-se que restaurações metálicas fundidas com proteção de cúspide deveriam ser indicadas em dentes que necessitem preparos cavitários quando a largura de istmo oclusal ultrapasse metade da distância intercuspídea. 
Em 1981, LARSON; DOUGLAS; GEISTFELD ${ }^{63}$, compararam os resultados da força necessária para fraturar dentes pré-molares superiores que receberam preparos cavitários tipo O e MOD (Figura 2) com abertura de 1/3 e 1/4 da distância intercuspídea, com aqueles obtidos para fraturar dentes hígidos.

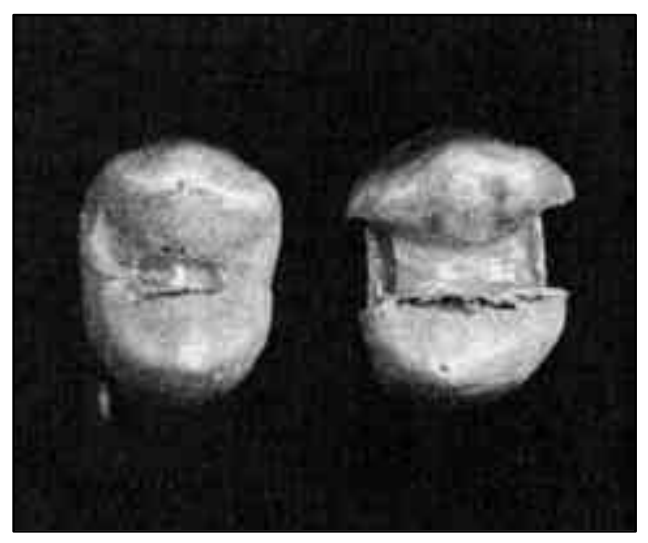

FIGURA 2 - Vista oclusal do preparo classe I (O) e do preparo classe II (MOD) realizados em dentes prémolares $^{63}$

A média dos valores encontrados no teste de resistência foi o seguinte: Grupo 1, controle - hígidos: 238,5 kg; Grupo 2, MOD (1/3): 97,2 kg; Grupo 3, MOD (1/4): 150,3 kg; Grupo 4, O (1/3): 95,6 kg; Grupo 5, O (1/4):149,9 kg. Pôde-se então verificar que, independente do tipo de preparo cavitário, bem como da extensão e dimensão da cavidade, que os dentes foram significantemente enfraquecidos, sendo que o fator que mais influenciou foi a largura da caixa oclusal. Aumentando-se o istmo da caixa oclusal de $1 / 4$ para 1/3, houve uma diminuição drástica na resistência do dente, observando-se que este foi o fator que mais influenciou em comparação com a confecção de caixas oclusais, que não reduz significantemente a resistência da estrutura dentária, se for mínima a quantidade removida. 
Estudou-se o mecanismo das fraturas de cúspides em dentes que receberam preparos cavitários tipo MOD, e que foram restaurados com amálgama dental. Para isso, BELL et al. ${ }^{8}$, em 1982, avaliaram a distribuição das tensões nos dentes através da utilização de microscopia eletrônica de varredura, sob ação de cargas oclusais, em um modelo de molar idealizado. Da análise por microscopia de vinte e seis cúspides de molares e pré-molares fraturados pôde-se verificar que a linha de fratura caminhou de maneira inclinada, descendente e para fora, a partir do assoalho da cavidade, formando um ângulo de 40 a $50^{\circ}$ a partir da parede pulpar do preparo cavitário em direção à margem gengival (Figura 3).

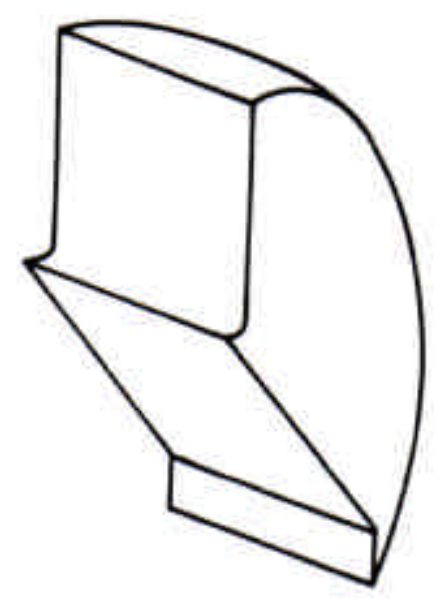

FIGURA 3 - Típica fratura de cúspide $^{8}$

Isto se deve ao fato de que as restaurações de amálgama intracoronárias não promovem suporte para as cúspides, tornando as paredes cavitárias cada vez mais fragilizadas ao longo do tempo. Este mecanismo de fratura pode ser modificado, principalmente na velocidade e orientação da fratura. Algumas trincas e fendas nas restaurações podem contribuir sobremaneira para que isto ocorra, diminuindo 0 
tempo de vida útil destas restaurações na cavidade oral, pois as cargas oclusais que incidem nos dentes ou sobre as restaurações concentram-se sempre sobre a base das cúspides, no ângulo formado entre a parede de fundo e a parede circundante da cavidade. Sugeriu-se que a proteção de cúspides seja realizada em restaurações extensas para que as cargas oclusais sejam mais uniformemente distribuídas, ou que se faça a utilização de materiais restauradores que sejam adesivos à estrutura dentária, promovendo uma ancoragem entre as paredes da cavidade.

SHARE et al. $^{97}$, em 1982, compararam o efeito de restaurações de amálgama e resina composta na resistência da estrutura dentária remanescente à fratura. Neste ensaio, foram utilizados quarenta pré-molares, que receberam preparos de cavidades tipo MOD, com istmo da caixa oclusal medindo $1 / 3$ da distância intercuspídea. As amostras foram divididas em quatro grupos da seguinte maneira:
A, restaurados com amálgama;
B, restaurados com resina composta sem condicionamento ácido de esmalte;
C, restaurados com resina composta com condicionamento ácido de esmalte;
D, não restaurados.

Os exemplares do grupo $A$ receberam aplicação de verniz copal previamente à aplicação do amálgama; os exemplares dos grupos B e C receberam a aplicação de uma resina de baixa viscosidade previamente à inserção da resina composta. Após a armazenagem dos dentes por 48 horas, submeteram-se os exemplares à carga de compressão axial simulando o contato oclusal sobre as vertentes triturantes a uma velocidade de $0,5 \mathrm{~mm} / \mathrm{min}$. Os resultados indicaram que os dentes do grupo $\mathrm{C}$ 
tiveram resistência à fratura superior aos dentes dos demais grupos, mostrando que restaurações de resina composta associadas ao condicionamento ácido de esmalte contribuem para aumentar a rigidez de dentes enfraquecidos por preparos cavitários.

O conceito de camada híbrida foi descrito pela primeira vez por NAKABAYASHI et al. ${ }^{79}$, em 1982, havendo a otimização da adesão ao tecido dentário através da interpenetração de um monômero, que continha radical hidrofílico e hidrofóbico, no interior do substrato dentinário desmineralizado (Figura 4).

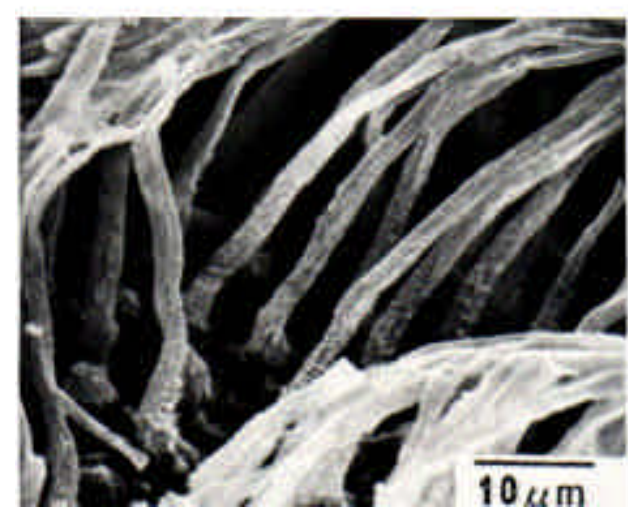

FIGURA 4 - Interpenetração de adesivo na intimidade dos túbulos. Microscopia após a descalcificação da dentina ${ }^{79}$

Amostras de esmalte e dentina humana e bovina foram asperizadas por discos de lixa de papel e submetidas a condicionamento ácido, através de uma mistura aquosa de ácido cítrico a $1 \%$ e cloreto férrico a 1\%, ou ácido cítrico a 10\% e cloreto férrico a 3\%, por 30 segundos. O monômero MMA isoladamente ou o 4-META a 5\% e TBB parcialmente oxidado foram misturados com 0,1 g de pó de PMMA para preparar o cimento. Pastilhas de acrílico foram então fixadas no esmalte e na dentina com este cimento e, após 24 horas, submetidas ao teste de cisalhamento, em uma máquina de ensaios universal. Uma quantidade igual de amostras foi preparada para análise 
em microscópio eletrônico de varredura. Verificou-se uma resistência ao cisalhamento da ordem de $13,9 \mathrm{mPa}( \pm 4,4)$ para a dentina humana e $15,1 \mathrm{mPa}$ $( \pm 5,3)$ para a dentina bovina, quando empregada a concentração de 10:3 de ácido cítrico e cloreto férrico. Na análise da microscopia eletrônica, foi observada a presença de "tags" de resinas no interior dos túbulos dentinários, indicando que a adesão ao substrato dentinário foi otimizado por infiltração e penetração, formandose uma camada ácido resistente. Este trabalho pioneiro contribuiu para o desenvolvimento de novos sistemas adesivos que são utilizados em dentina umedecida e na simplificação do uso dos mesmos.

O efeito das dimensões das cavidades MOD na resistência de dentes pré molares superiores também foi estudado por BLASER et al. ${ }^{9}$, em 1983. Utilizaram uma amostra de cem dentes, que foram subdivididas em cinco grupos de vinte dentes cada, constituindo-se então (Figura 5):
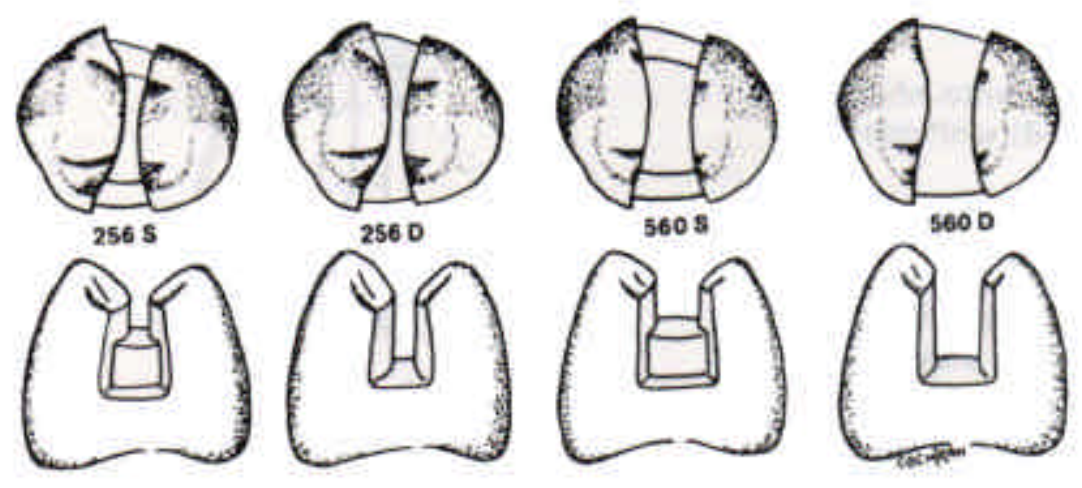

FIGURA 5 - Preparos cavitários com diferentes dimensões realizados nos pré- molares ${ }^{9}$

Controle - dentes hígidos

$256 \mathrm{~S}$ - Preparo MOD - istmo estreito $0,9 \mathrm{~mm}$ / caixa oclusal rasa $1,5 \mathrm{~mm}$ 
$560 \mathrm{~S}$ - Preparo MOD - istmo largo $1,6 \mathrm{~mm}$ / caixa oclusal rasa $1,5 \mathrm{~mm}$ 256D - Preparo MOD - istmo estreito 0,9 mm / caixa oclusal profunda

\section{$3,0 \mathrm{~mm}$}

560D - Preparo MOD - istmo largo 1,6 mm / caixa oclusal profunda 3,0 $\mathrm{mm}$.

Levou-se ainda em consideração, se havia influência do tamanho dos dentes na resistência à fratura, dividindo-se os corpos de prova em dois grupos de cinqüenta, de acordo com as dimensões combinadas mésio-distal e vestíbulo-lingual. Submeteram-se os dentes à carga oclusal, aplicada através de uma esfera de aço de $4,8 \mathrm{~mm}$ de diâmetro, numa velocidade de $10 \mathrm{~mm} / \mathrm{min}$, apoiada nas vertentes triturantes. Da análise dos resultados, pôde-se verificar que a profundidade da caixa oclusal foi o fator que mais influenciou no enfraquecimento do dente e não a largura do istmo da caixa oclusal. Observou-se ainda que os dentes que receberam preparos cavitários com istmo oclusal estreito e profundidade da caixa oclusal rasa foram tão resistentes à fratura quanto os dentes do grupo-controle. Por outro lado, os dentes que receberam um preparo cavitário com istmo oclusal largo e profundidade da caixa oclusal grande foram os que apresentaram menor resistência à fratura, indicando-se a realização de restaurações com proteção de cúspide para estes casos. Em relação ao tamanho dos dentes, os resultados mostraram que aqueles com dimensões maiores tendem a ser mais resistentes à fratura que dentes com dimensões menores.

A resistência à fratura de dentes pré- molares superiores, com lesões cariosas situadas em diferentes faces dentárias foi estudada por NAVARRO et al. $^{81}$, em 1983. Estes autores testaram ainda a resistência de dentes com remoção do teto da 
câmara pulpar e preparos classe II MOD, bem como a de dentes que receberam restaurações metálicas fundidas com proteção de cúspide. Desta forma, os dentes foram divididos em 6 grupos, a saber: grupo A, dentes hígidos (controle); grupo B, dentes com lesão cariosa na face oclusal; grupo $C$, dentes com lesão na face proximal, sem comprometer a crista marginal; grupo $D$, dentes com lesão na face proximal, com envolvimento da crista marginal; grupo $\mathrm{E}$, dentes com remoção do teto da câmara pulpar e preparo MOD; grupo F, dentes com remoção do teto da câmara, preparo MOD com proteção de cúspide mais RMF (Figuras 6 e 7).

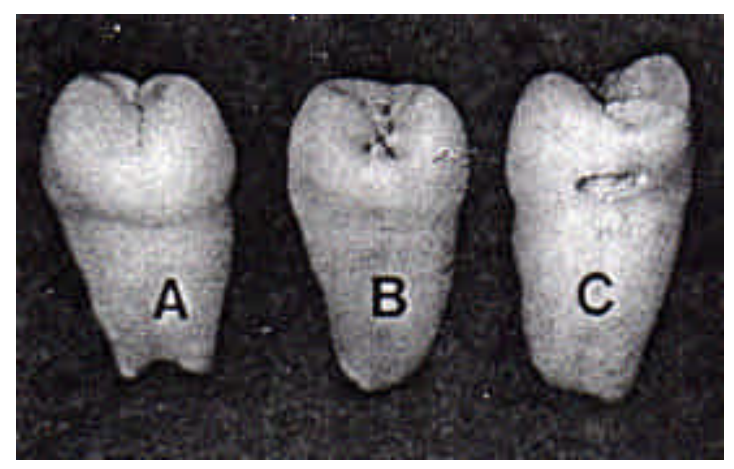

FIGURA 6 - Dente hígido (A)

Lesão cariosa oclusal (B)

Cárie proximal $(\mathrm{C})^{81}$

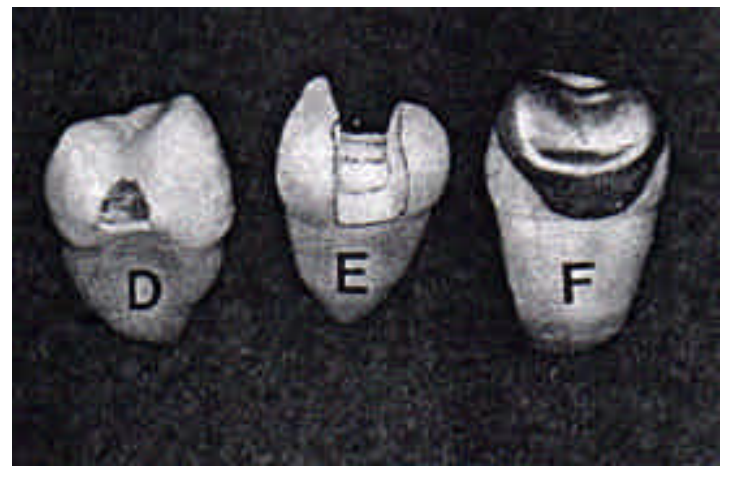

FIGURA 7 - Cárie proximal com envolvimento da crista marginal (D)

Remoção do teto da câmara (E) Remoção do teto e R.M.F. com proteção de cúspide $(F)^{81}$ 
Os corpos de prova foram submetidos a teste de compressão axial através de uma esfera de aço de $4 \mathrm{~mm}$ de diâmetro, a uma velocidade de 0,5 mm/min. As médias obtidas foram: A: 175,35 kgf; B: 126,25 kgf; C: 78,60 kgf; D: 49,70 kgf; E: 21,15 kgf e F: 305,20 kgf. Pôde-se verificar que, nos dentes em que houve a remoção do teto da câmara pulpar, houve uma redução de $90 \%$ da resistência à fratura em relação aos dentes do grupo-controle, e que a utilização de restaurações metálicas fundidas com proteção de cúspide possibilitou a obtenção de resultados significantemente maiores, bem superiores aos obtidos pelos dentes hígidos. Salientou-se ainda que a preservação sempre que possível de estruturas de reforço, como cristas marginais e o teto da câmara pulpar, quando da realização de preparos cavitários, são necessários para a preservação da resistência do dente.

PEREIRA et al. ${ }^{88}$, em 1983, propuseram avaliar a resistência à fratura de molares superiores submetidos a diversos tipos de preparos cavitários. Foram selecionados 83 molares superiores, os quais foram divididos em 4 grupos, havendo um grupo controle (de 11 dentes hígidos) e os demais portadores de cavidades oclusais e ocluso-proximais, sendo divididos ainda com e sem remoção do teto da câmara pulpar. As cavidades preparadas foram do tipo oclusal, mésio-oclusal e mésio-ocluso-distal., com profundidade média de 2,5 mm, tanto para a caixa oclusal como para as caixas proximais. A caixa oclusal teve a largura do istmo correspondente a 1/3 da distância vestíbulo-lingual do dente. Estes espécimes foram submetidos ao carregamento axial de compressão, em uma máquina de ensaios universal, por meio de uma esfera de $4 \mathrm{~mm}$ de diâmetro, a uma velocidade de 0,5 $\mathrm{mm} / \mathrm{min}$. Verificou-se que, quanto maior a quantidade de tecido dentário removido pelo preparo cavitário, menor a resistência à fratura. Enfatizou-se ainda que a 
remoção do teto da câmara pulpar reduziu a resistência à fratura dos dentes (em cerca de $80 \%$ ), independente do tipo de preparo cavitário. Observou-se ainda que as variações nos preparos cavitários demonstraram ser menos danosas, em relação à resistência à fratura, devido ao grande volume de estrutura dentária presente nos molares, do que em relação aos pré-molares superiores, cuja forma anatômica favorece à separação das cúspides durante os esforços mastigatórios.

Um estudo não destrutivo em que se avaliou a flexão da cúspide vestibular de pré-molares superiores foi realizado por MORIN et al. $^{77}$, em 1984. Selecionaram-se doze dentes, sendo que um deles serviu como controle, não recebendo qualquer tipo de tratamento. Os demais receberam preparos tipo oclusal (1 dente) e MOD (os elementos restantes), com istmo oclusal de $1 / 4$ da distância intercuspídea. Dois dentes com preparo MOD receberam restaurações adesivas, com condicionamento ácido prévio, e três dentes, restaurações não adesivas (1 com amálgama e 2 com resina composta sem condicionamento ácido). Seis amostras que receberam preparo cavitário não foram restauradas com nenhum tipo de material. Os resultados mostraram que aqueles dentes que perderam estrutura dentária pelo preparo cavitário e não foram restaurados apresentaram grande flexão de cúspide vestibular, com exceção do dente que recebeu preparo apenas oclusal. Os dentes que foram submetidos à carga oclusal tiveram medidores de tensão acoplados à face vestibular dos corpos de prova. Os dentes que foram preparados e restaurados com restaurações adesivas exibiram uma baixa flexão cuspídea, com resultados próximos àquele obtido pelo dente hígido (Figura 8). Os três dentes que receberam restaurações não adesivas (duas de resina composta e uma de amálgama) mostraram grande flexão cuspídea, com resultados semelhantes àqueles obtidos 
pelos dentes preparados e que não receberam restauração. Concluiu-se que houve um aumento na resistência à deformação nos dentes restaurados com restaurações adesivas, com o restabelecimento de sua rigidez entre 68 e $88 \%$ dos valores apresentados pelos dentes hígidos, com as cúspides apresentando reduzida deflexão, o que indica o possível selamento das fendas marginais.
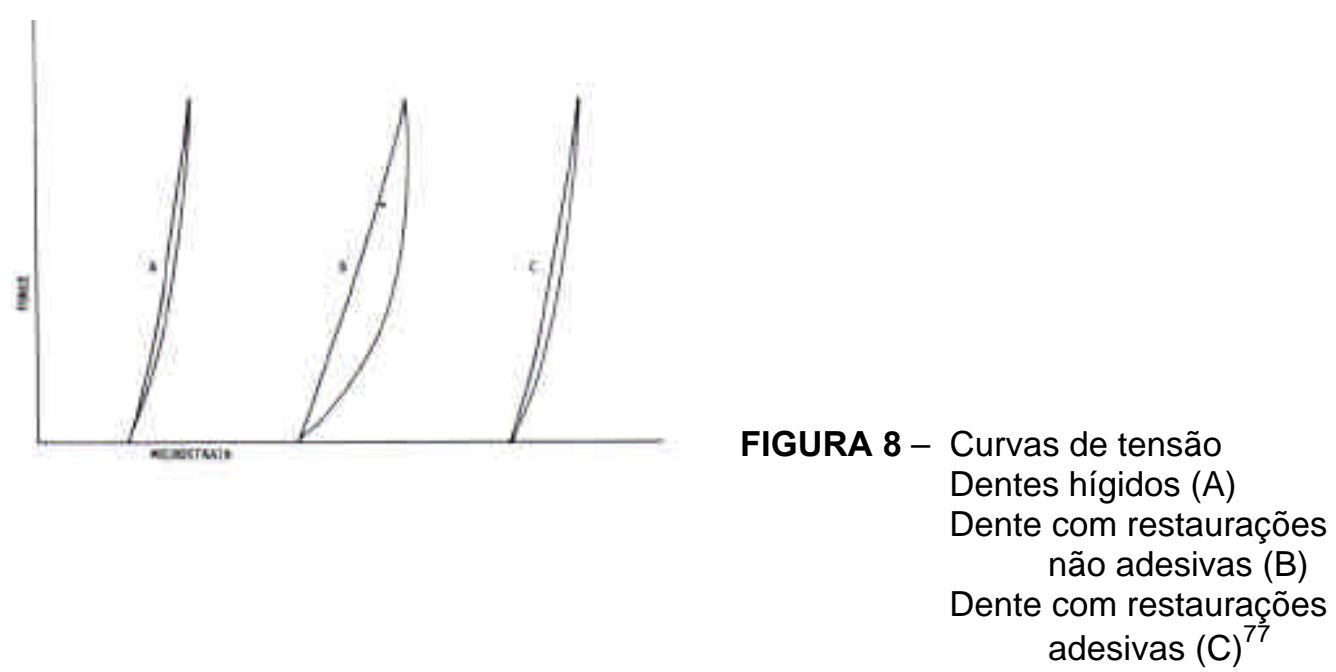

A resistência à fratura de dentes posteriores restaurados com resina composta foi investigada in vitro por LANDY; SIMONSEN ${ }^{62}$, em 1984, que selecionaram 45 pré-molares superiores, dividindo-os em seis grupos. 0 grupo 1 funcionou como controle (hígidos) e os demais grupos receberam preparos cavitários tipo MOD, com largura de $1,0 \mathrm{~mm}$ e 2,0 $\mathrm{mm}$ de profundidade. Assim os grupos ficaram constituídos:

Grupo 2 - dentes preparados e não restaurados

Grupo 3 - dentes preparados, restaurados com resina composta, 
associada a duas camadas de adesivo, fraturados 14 dias após as restaurações serem realizadas;

Grupo 4 - dentes preparados, restaurados com resina composta associada a duas camadas de adesivo, fraturados 4 horas após as restaurações serem realizadas;

Grupo 5 - dentes preparados, restaurados com resina composta associada a um agente de união resinoso convencional, fraturados 4 horas após as restaurações serem realizadas; Grupo 6 - dentes preparados, restaurados com resina composta associada a uma camada de adesivo, fraturados 24 horas após as restaurações serem realizadas.

Submeteram-se os dentes a teste de compressão (não sendo especificado o modo de aplicação, nem com que velocidade) numa máquina de ensaios universal. Os resultados mostraram que os preparos cavitários enfraqueceram significantemente os dentes e que o uso de resina composta, associada com o agente de união convencional ou duas camadas de adesivo, restabelece apenas parte da rigidez perdida nos preparos. Quando se aplicou apenas uma camada de adesivo, houve um maior restabelecimento na resistência do dente.

Ainda em 1984, com o intuito de se comparar a resistência à fratura de dentes restaurados com amálgama a dentes restaurados com resina composta fotopolimerizável, MISHELL; SHARE; NATANSON ${ }^{73}$ utilizaram trinta dentes prémolares, dividindo-os em dois grupos, que receberam o mesmo preparo cavitário, classe II MOD, com profundidade de $6 \mathrm{~mm}$ (a partir da ponta de cúspide) e largura de istmo oclusal de $3,0 \mathrm{~mm}$. Assim os grupos ficaram constituídos: grupo A, que 
receberam preparos cavitários e restaurações com amálgama e grupo B, que receberam preparos cavitários com um ligeiro bisel no cabo superficial e restaurações com resina composta fotopolimerizável. Submeteram-se os dentes, após uma semana, a testes de compressão axial em uma máquina de ensaios universal, numa angulação de $30^{\circ}$ na cúspide vestibular, numa velocidade de 0,25 $\mathrm{mm} / \mathrm{min}$ (não foi especificado o modo de aplicação). Pôde-se verificar que a média dos resultados apresentados pelo grupo B foi significantemente maior que a média dos valores apresentados pelo grupo $\mathrm{A}$, evidenciando que a resina composta estaria indicada em dentes enfraquecidos por cavidades extensas no intuito de reforçar o remanescente dentário.

CAVEL et al. ${ }^{26}$, em 1985, relataram uma pesquisa clínica onde analisaram os vários fatores envolvidos na fratura de cúspides. Cento e dezoito dentes posteriores foram examinados na clínica da Universidade de Creighton que possuíam pelo menos uma cúspide fraturada, sendo anotados os seguintes dados: o arco (superior ou inferior), o grupo dentário (pré ou molar), a cúspide fraturada (funcional ou não funcional), o tipo de restauração presente (e o número de superfícies restauradas), a abertura de istmo (amplo, médio ou estreito) e o dente antagonista. Da análise dos resultados, observou-se que não houve predominância entre arcadas. $\mathrm{Na}$ arcada superior, houve igual ocorrência de fratura entre molares e pré molares. $\mathrm{Na}$ arcada inferior, $90 \%$ das fraturas ocorreram nos molares e $10 \%$ em pré-molares. Os prémolares superiores tiveram $62 \%$ de fraturas nas cúspides não funcionais, ou seja, a cúspide vestibular e $38 \%$ restantes em cúspides funcionais. O tipo de restauração mostrou que a preponderância de fratura de cúspide estava associada a dentes restaurados com amálgama com três ou mais superfícies e que, quanto maior a 
amplitude do istmo, parece haver uma associação com a incidência de fratura de cúspide. Com exceção dos pré molares inferiores, todas as categorias de dentes mostraram uma alta incidência de fratura de cúspides em cúspides não-funcionais, sendo mais evidente em molares inferiores. Uma possível explicação para esta ocorrência pode ser encontrada no desenho anatômico e da posição dos dentes no arco. As cúspides funcionais tendem a se localizar próximo ao centro do dente para absorver forças oclusais e direcioná-las axialmente. As cúspides não-funcionais geralmente não possuem este alinhamento axial de forma que as forças oclusais aplicadas a estas cúspides terão um componente lateral maior, e as fraturas de cúspides são mais prováveis de ocorrer. A ausência de alinhamento axial é mais pronunciada nos molares inferiores, onde os dentes possuem uma inclinação que poderia causar um aumento na incidência de fratura de cúspides não funcionais. $O$ mesmo fenômeno pode ser demonstrado na arcada superior, onde uma leve vestíbuloversão faz com que cúspides não funcionais fiquem numa posição que aumenta a susceptibilidade deles à fratura. Desta forma, a anatomia poderia ser parcialmente responsável pela susceptibilidade à fratura, e a inclinação dos dentes poderia aumentar esta predisposição. Outro fator que possivelmente explica a diferença na incidência de fratura entre cúspides funcionais e não-funcionais é que a oclusão das cúspides funcionais com o dente antagonista é do tipo cúspide-fossa, que fornece o parâmetro de suporte da inclinação da entrada e saída da cúspide. As cúspides não-funcionais geralmente não ocluem desta maneira. Nestas, o tipo de inclinação faz com que haja um aumento do componente lateral das forças direcionadas contra a cúspide, tornando-a mais susceptível à fratura. Os resultados mostrados neste estudo revelaram que o tipo de restauração e a abertura de istmo 
tiveram uma grande relação com a susceptibilidade do dente à fratura. Em todas as categorias de dentes, quanto maior o número de superfícies restauradas e/ou maior o istmo, maior a chance de uma cúspide fraturar. Os resultados mostraram dados contrários à maioria de estudos laboratoriais. Isto talvez se deve ao fato de que estes estudos não reproduzem uma força mastigatória corretamente, sendo que, na maioria deles, se aplicam forças contínuas, até que ocorra fratura. Clinicamente, as forças suportadas pelos dentes são de magnitude constante e são aplicadas por longos períodos de tempo. Esta diferença na aplicação de forças poderia também afetar o padrão de fadiga e eventualmente o padrão de fratura dos dentes.

A resistência à fratura de dentes pré-molares superiores restaurados com resina composta também foi avaliada por BAKKE et al. ${ }^{6}$ em 1985 . Foram selecionados sessenta dentes, dividindo-se a amostra em seis grupos, sendo que o grupo I, de dentes hígidos, funcionou como controle. Os demais grupos receberam preparos tipo MOD com 3,0 mm de profundidade, ficando assim constituídos:

grupo II - preparo cavitário e permaneceu sem restauração;

grupo III - preparo cavitário e restaurou-se com amálgama;

grupo IV - preparo cavitário e restauração de resina composta (P 30)

com somente condicionamento ácido prévio à restauração;

grupo V - preparo cavitário e restauração de resina composta com

somente aplicação de agente de união, sem condicionamento ácido;

grupo VI - preparo cavitário e restauração de resina composta com condicionamento ácido e aplicação de um agente de união resinoso fotopolimerizável. 
Os corpos de prova foram submetidos a testes de compressão axial após sete dias, em uma máquina de ensaio universal. Pode-se verificar através dos resultados que os dentes que foram preparados e não restaurados apresentaram grande diminuição na resistência à fratura. O grupo que recebeu restaurações a amálgama não mostrou aumento na resistência à fratura ( $74,23 \mathrm{kgf}$ ) em relação aos dentes com preparo e não restaurados $(78,71 \mathrm{kgf})$. Os demais grupos que receberam restaurações de resina composta mostraram grande incremento na resistência à fratura em relação aos dentes do grupo II aproximando a valores do grupo controle (141 kgf). Comparando-se os grupos IV (104,21 kgf), V (117,57 kgf) e VI

( 110,84 kgf), não houve diferenças estatísticas significantes entre eles.

Outro autor que testou a resistência à fratura de dentes pré-molares que foram restaurados com resina composta foi $E A K L E^{33}$, em 1986. Para este estudo, foram selecionados quarenta e oito dentes pré-molares superiores hígidos, que receberam preparos de cavidade tipo MOD, com istmo oclusal com largura aproximada de 1/4 da distância intercuspídea. Dividiu-se a amostra em três grupos de dezesseis dentes cada que receberam o seguinte tratamento:

grupo 1 : dentes preparados e não restaurados;

grupo 2 : dentes preparados e restaurados com resina composta (P30) associada a condicionamento ácido de esmalte e adesivo de esmalte;

grupo 3 : dentes preparados e restaurados com resina composta (P30) associada a condicionamento ácido de esmalte e adesivo de esmalte e dentina (Scotchbond). 
Após 24 a 48 horas, realizaram-se testes de carregamento axial em uma máquina de ensaios universal, utilizando-se uma esfera de $4,76 \mathrm{~mm}$ de diâmetro, a uma velocidade de $5,0 \mathrm{~m} . \mathrm{m} . / \mathrm{min}$. até que os dentes fraturassem. Verificou-se que as amostras do grupo 3 apresentaram maior resistência à fratura (120 $\pm 27,3$ kgf) em relação aos grupos 1 (83 \pm 29,9 kgf) e 2 (95,5 \pm 18,6 kgf), havendo diferença estatística significante. Entre os grupos 1 e 2, não houve diferença significante quando se compararam os resultados. Concluiu-se que a maior resistência observada no grupo 3 é devido ao fato de que este grupo recebeu adesivo de esmalte e dentina, possibilitando ao material restaurador uma maior área de união com o tecido dentário. O mesmo não pode ser observado no grupo 2, já que houve uma adesão mais localizada em esmalte. Embora os resultados tenham mostrado que dentes restaurados com resina composta, associada a condicionamento ácido e sistema adesivo esmalte/dentina, aumentem a resistência à fratura dos mesmos, as propriedades físicas destes materiais devem ser aprimoradas para que se possa indicá-los na prevenção de fraturas dentárias em casos de dentes enfraquecidos.

No mesmo ano, EAKLE; MAXWELL; BRALY $Y^{35}$ publicaram um trabalho revelando dados colhidos durante um ano e meio, em relação à ocorrência de fratura de dentes posteriores em um atendimento de emergência da faculdade de Odontologia da Universidade da Califórnia. Foram examinados cento e noventa e um pacientes com duzentos e seis dentes fraturados de acordo com critérios préestabelecidos. Pode-se observar que os dentes mais freqüentemente envolvidos com fratura são os primeiros molares inferiores e os de menor freqüência, os prémolares inferiores. Quando se compara a ocorrência de fratura entre as arcadas superior e inferior, se encontra igual predominância entre eles. Em relação aos 
dentes superiores, os molares e pré-molares fraturaram quase que com a mesma freqüência. As cúspides mais envolvidas com fratura são, no caso dos molares inferiores, as linguais, numa proporção de 2:1 em relação às vestibulares. Já na arcada superior, em relação aos molares, as cúspides vestibulares e linguais fraturaram-se quase que com a mesma freqüência. Os pré-molares inferiores têm as cúspides linguais mais envolvidas com fratura, numa proporção de 3:1 em relação às cúspides vestibulares, e encontrando-se nos pré-molares superiores uma leve predominância das cúspides linguais em relação à vestibular. Verificou-se ainda que cerca de $91 \%$ dos dentes fraturados eram restaurados, e destes, em torno de $93 \%$, receberam restaurações de amálgama. O tipo predominante de preparo que os dentes possuíam era do tipo classe II (77\%), observando-se que poucos dentes com restaurações conservativas e com crista marginal intacta possuíam fratura e que 94\% delas ocorreram em dentes com abertura de istmo de 1/3 ou mais da distância intercuspídea, concluindo-se que quanto mais se remove estrutura dentária do centro do dente, mais fraco o remanescente dentário. Além disso, outros fatores de risco expõem os dentes à fratura, como desgaste de cúspides, relação de oclusão cúspide-fossa, restaurações extensas, trauma oclusal e ainda hábitos parafuncionais. Sugeriu-se ainda que quando o dente estiver enfraquecido deve-se realizar a proteção das cúspides, evitando-se restaurações extensas de amálgama.

A influência do tipo de material restaurador na resistência à fratura de dentes pré-molares foi estudada por GELB et al. ${ }^{46}$, em 1986. Neste estudo, ainda foi avaliada a ação do condicionamento ácido em esmalte, seguido da aplicação de um adesivo nos dentes que receberam resina composta. Realizaram-se preparos cavitários em pré-molares superiores no intuito de se avaliar a resistência à fratura 
comparando-se os resultados obtidos de acordo com o tratamento que receberam. Selecionaram-se trinta e nove dentes, sendo que o grupo A constituiu o grupocontrole não recebendo qualquer tratamento. Os demais grupos receberam o mesmo preparo cavitário tipo MOD, com profundidade pulpar de 2,5 $\mathrm{mm}$ e largura de istmo de $1,0 \mathrm{~mm}$, e foram divididos conforme o tratamento restaurador, assim:

Grupo B: preparo cavitário MOD , sem restauração (6 dentes);

Grupo C: preparo cavitário MOD, restaurados com amálgama Dispersalloy (6 dentes);

Grupo D: preparo cavitário MOD, restaurados com resina composta Silar - 3M, sem condicionamento ácido (6 dentes);

Grupo E: preparo cavitário MOD com bisel no cavo superficial, restaurados com resina composta associado a condicionamento ácido do esmalte (14 dentes).

Após a conclusão dos procedimentos restauradores, submeteram-se os corpos de prova a teste de resistência à fratura em uma máquina de ensaios universal, com um dispositivo especialmente desenhado (não demonstrado no trabalho) a uma velocidade de $0,05 \mathrm{~mm} / \mathrm{min}$. Os resultados mostraram que os dentes do grupo $E(171 \pm 45$ kgf $)$ mostraram uma média de resistência à fratura significantemente mais resistente que o grupo controle (138 \pm 26 kgf) e em relação aos grupos B (86 $\pm 23 \mathrm{kgf}), \mathrm{C}(104 \pm 27 \mathrm{kgf})$ e $\mathrm{D}(97 \pm 25 \mathrm{kgf})$. Com base nestes resultados, concluiu-se que dentes com preparos cavitários que recebem restaurações adesivas, com aplicação do ácido em esmalte favorece o restabelecimento da resistência à fratura, já que torna as cúspides mecanicamente 
unidas, não se observando o mesmo em dentes que receberam restaurações à amálgama ou de resina composta (sem esmalte condicionado) onde não houve adesividade à estrutura dentária.

Em 1986, MACKENZIE ${ }^{69}$ também avaliou a capacidade das resinas compostas, associadas ao condicionamento ácido do esmalte e à utilização de um adesivo de esmalte em reforçar cúspides enfraquecidas após o preparo cavitário. Selecionaram-se pares de pré-molares superiores, extraídos por motivos ortodônticos, de um mesmo paciente. Todos os exemplares receberam preparos cavitários de forma que apenas uma das cúspides ficasse enfraquecida, sendo que apenas um dos dentes recebeu restauração. Submeteram-se os dentes dos dois grupos aos testes de compressão em uma máquina de ensaios Universal, variandose a velocidade em $0.5 \mathrm{~mm} / \mathrm{min}$., $5 \mathrm{~mm} / \mathrm{min}$. e em $20 \mathrm{~mm} / \mathrm{min}$ (Figura 9).

FIGURA 9 - Dente pré-molar que recebeu apenas preparo cavitário, sob ação de uma carga de compressão com um cilindro de aço $^{69}$

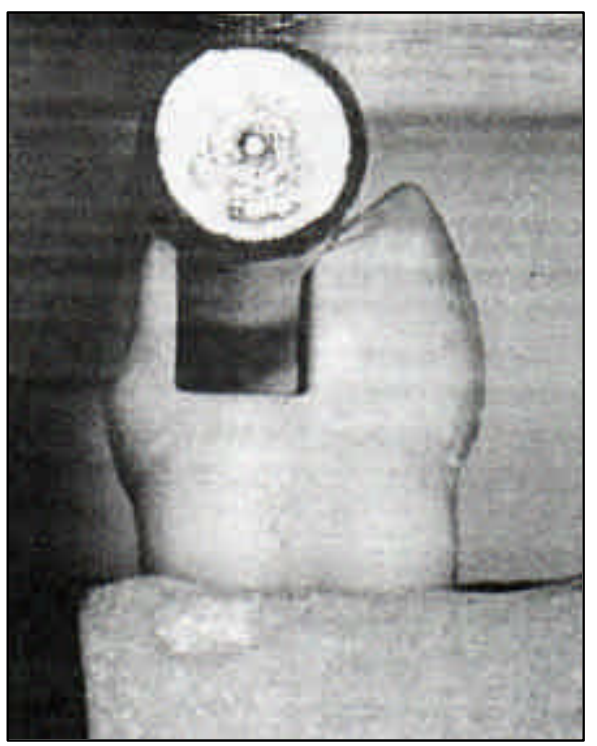

Os resultados apresentados pelos dentes restaurados foram bem maiores que os apresentados pelos não restaurados, numa média percentual entre $80,7 \%$ até $96,4 \%$ 
( 5 e 20 m.m./min.), mostrando ainda em alguns casos, uma força de $362 \%$ ( 0,5 m.m./min.) a mais para que se atingisse a fratura. Enfatizou-se a possibilidade da utilização de restaurações de resina composta associada a condicionamento do esmalte e à utilização de adesivo de esmalte, no sentido de reforçar cúspides enfraquecidas após a realização dos preparos cavitários.

No mesmo ano, objetivando comparar a resistência à fratura de dentes restaurados com resina composta e amálgama, STAMPALIA et al. ${ }^{104}$ selecionaram 30 pré-molares humanos hígidos que receberam preparos cavitários tipo MOD com uma profundidade de $3 \mathrm{~mm}$, com ausência de bisel nas margens. Um dos grupos (grupo I), serviu como controle não recebendo qualquer tratamento. O grupo II recebeu preparos MOD do tipo "slot" e foram restaurados com amálgama e os do grupo III foram restaurados com resina composta P-10 e adesivo Scotchbond. As amostras do grupo II receberam duas camadas de verniz (S.S. White Co.) aplicadas sobre dentina e esmalte. Uma matriz foi colocada ao redor dos dentes e, então, estes foram restaurados com amálgama Dispersalloy (3M Dental Products). As amostras do grupo III foram condicionadas com ácido fosfórico a 37\% sobre todo o esmalte, durante 60 segundos, sendo lavadas a seguir por 45 segundos e secas por 30 segundos. Após o posicionamento da matriz, duas camadas do adesivo Scothbond A e B foram aplicadas sobre o esmalte e a dentina; e espalhadas com ar. Imediatamente após, a resina P-10 foi misturada em partes iguais (pastas A e B) e injetadas no preparo por meio da seringa Centrix em excesso. Dez minutos após a inserção da resina, a matriz foi removida e os procedimentos de polimento realizados. Submeteram-se os dentes a ensaio de carregamento axial, por meio de um cilindro com diâmetro variando entre 3,9 a $5,0 \mathrm{~mm}$, tocando-se apenas as 
vertentes de cúspide, a uma velocidade de $5 \mathrm{~cm} / \mathrm{min}$. (Figura 10). As médias apresentadas pelo grupo controle $(127.8 \pm 33,4 \mathrm{~kg})$ foram significantemente maiores que as apresentadas pelos grupos II $(78,7 \pm 24,6 \mathrm{~kg})$ e III $(78,3 \pm 19 \mathrm{~kg})$. Observouse que não houve diferença estatisticamente significante entre as cargas necessárias para a fratura dos dentes restaurados com resina composta e amálgama e que a carga necessária para fraturar os dentes foi dependente somente do remanescente de tecido e não do material restaurador.

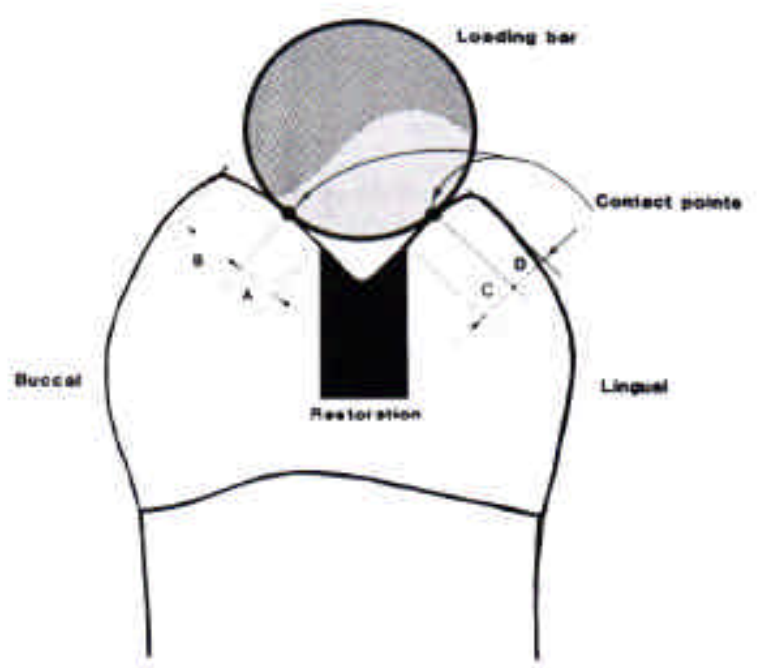

FIGURA 10 - Teste de resistência à fratura através da ação de uma barra de aço aplicada às vertentes de cúspides ${ }^{104}$

Ainda em 1986, McCULLOCK; SMITH ${ }^{71}$ compararam o reforço cuspídeo, obtido através da realização de restaurações adesivas e com restaurações não adesivas. Quarenta e oito pares de primeiros pré-molares hígidos foram selecionados, sendo que os dentes receberam preparos cavitários tipo MOD e apenas um deles foi restaurado, sendo então os espécimes distribuídos em sete grupos de acordo com o tratamento que receberam: 
Grupo 1 - condicionamento ácido do esmalte/ adesivo de esmalte/ resina composta aplicada pela técnica de incremento único;

Grupo 2 - condicionamento ácido do esmalte/ adesivo de esmalte/ resina composta aplicada em dois incrementos;

Grupo 3 - condicionamento ácido do esmalte/ adesivo de esmalte e dentina/ resina composta aplicada pela técnica de incremento único;

Grupo 4 - condicionamento ácido do esmalte/ adesivo de esmalte e dentina/ resina composta aplicada em dois incrementos;

Grupo 5 - aplicação de cimento de ionômero de vidro associado à resina composta;

Grupo 6 - cermet;

Grupo 7 - amálgama.

Submeteram-se os corpos de prova a testes de compressão axial, em uma máquina de ensaios Universal, com um cilindro em contato apenas com as vertentes de cúspide, a uma velocidade de $0,5 \mathrm{~m} . \mathrm{m} . / \mathrm{min}$. Pôde-se observar através dos resultados que os materiais associados a técnicas adesivas aumentaram consideravelmente a resistência dos dentes à fratura, de duas a seis vezes em relação aos dentes preparados e não restaurados, conforme a técnica utilizada. Verificou-se ainda que o amálgama não reforça os dentes preparados, predispondoos à fratura, concluindo-se que os dentes enfraquecidos pelos preparos cavitários 
devem ser restaurados com materiais e técnicas adesivas, sem a necessidade de procedimentos radicais e invasivos, como a proteção ou cobertura de cúspides.

JENSEN et al. ${ }^{58}$ em 1987 compararam a resistência à fratura de dentes e a deflexão das cúspides de pré-molares superiores, restaurados com resina composta na forma direta e restaurações intracoronárias de cerâmica. Foram confeccionados preparos cavitários tipo MOD, sem proteção cuspídea, com largura de istmo oclusal de1/3 da distância intercuspídea. Um grupo de pré-molares hígidos, sem qualquer tratamento funcionou como controle. Constituíram-se os grupos, então em : grupo 1 - dentes preparados com cavidades do tipo MOD e não restaurados; grupo 2 dentes preparados e restaurados com resina composta P30 ; grupo 3 - dentes preparados e restaurados com inlays de porcelana; grupo 4 - dentes hígidos (controle). Aplicou-se a resina composta em três camadas incrementais, realizandose previamente o condicionamento ácido do esmalte além da utilização dos sistemas adesivos. As restaurações parciais indiretas de cerâmica receberam tratamento na superfície interna com ácido hidrofluorídrico a 10\%, e foram cimentadas com cimento resinoso. Para os testes de deflexão de cúspide, foi aplicada uma força de $12 \mathrm{~kg}$ através de uma barra triangular tocando as vertentes de cúspide que tiveram acoplados medidores de força à superfície externa (Figura 11). Para estes testes, observou-se que houve uma redução significante na resistência nos dentes que receberam apenas preparos cavitários. O grupo de dentes restaurados com restaurações indiretas de porcelana exibiu maiores resultados, significantemente maiores que os valores mostrados pelo grupo de dentes restaurados com resina direta. Em relação aos teste de compressão, foram realizados em uma máquina de ensaios universal, com uma barra triangular, que tocou somente as cúspides 
vestibular e palatina, a uma velocidade de $0,05 \mathrm{~cm} / \mathrm{min}$., aplicando-se agora uma força até que houvesse fratura de cúspide. Verificou-se através dos resultados que nos dois casos houve o restabelecimento da resistência à fratura, mostrando médias próximas aos do grupo controle, e com resultados equivalentes entre si, mostrando comportamentos semelhantes, com apenas o grupo 1 apresentando valores estatisticamente menores em relação aos demais grupos.

FIGURA 11 - Teste de carregamento axial, para avaliar-se a flexão de cúspide ${ }^{58}$

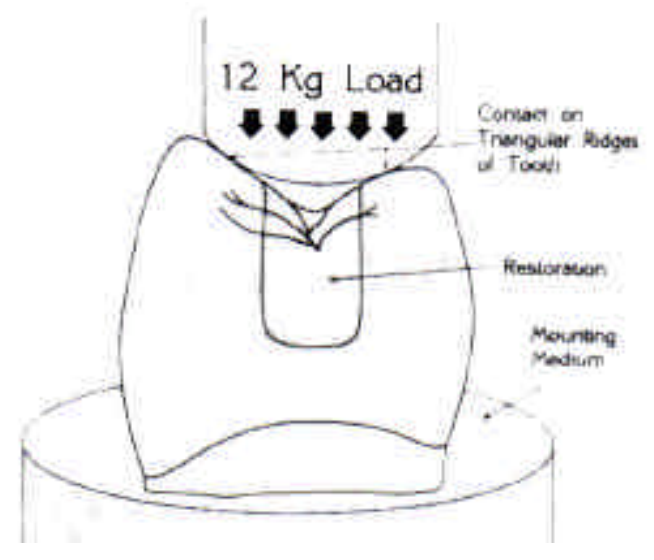

Outro estudo comparativo de resistência à fratura de dentes restaurados com resina composta com a resistência de dentes restaurados com amálgama foi realizado por JOYNT et al..$^{59}$ em 1987, que utilizaram quarenta e um dentes pré molares superiores que foram divididos em 5 grupos, sendo que o grupo I não recebeu tratamento (hígidos). Os demais grupos receberam preparos cavitários tipo MOD, com um istmo de $1 / 3$ da distância intercuspídea (Figura 12), ficando assim constituídos:

grupo II - dentes preparados e não restaurados (8 dentes);

grupo III - dentes preparados e restaurados com 


\author{
amálgama (9 dentes); \\ grupo IV - dentes preparados e restaurados com resina \\ composta e ângulo cavo superficial da cavidade \\ em $90^{\circ}$ (8 dentes); \\ grupo $\mathrm{V}$ - dentes preparados e restaurados com resina \\ composta e ângulo cavo superficial da cavidade \\ biselado (8 dentes).
}

FIGURA 12 - Preparo cavitário realizado nos pré-molares, sendo que A corresponde a $1 / 3$ de $\mathrm{B}$ e $\mathrm{C}$ corresponde a $1 / 3$ de $D^{59}$

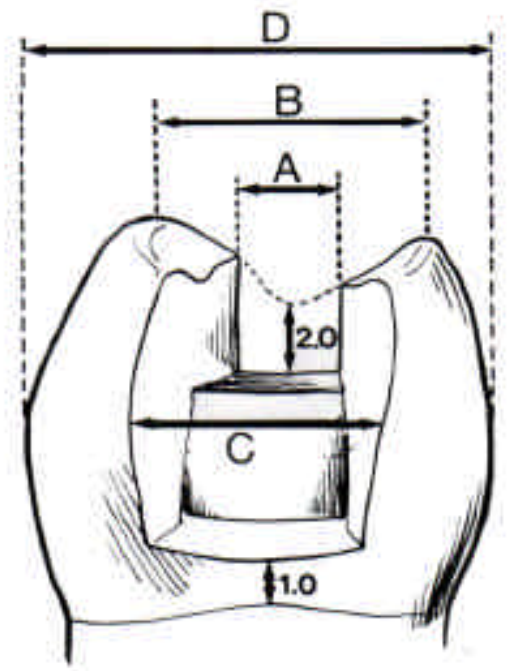

Os dentes restaurados com resina composta receberam previamente condicionamento ácido em esmalte sem que se aplicasse um adesivo. Armazenaram-se os dentes por setenta e duas horas, e então, submeteram-se os dentes aos testes de resistência à fratura, sob ação de uma carga axial em uma máquina de ensaios universal, utilizando-se dois cilindros de metal com 1,985 mm de diâmetro cada, a uma velocidade de 0,1 m.m./min. O grupo de dentes preparados 
e que não recebeu restauração mostrou resultados significantemente menores (58 \pm 13 kgf) em relação ao grupo controle (99 \pm 10 kgf). Os grupos 3 (74 \pm 12 kgf), 4 ( 73 $\pm 14 \mathrm{kgf})$ e 5 (70 $\pm 6 \mathrm{kgf})$, que foram restaurados, não tiveram a resistência completamente restabelecida, quando se comparou ao grupo controle. Entre os materiais restauradores, não houve diferença significante entre restaurar-se com amálgama e com resina composta fotopolimerizável, na resistência à fratura, nem entre os grupos que receberam restaurações de resina composta com bisel e sem bisel. Explicaram-se estes resultados pelo fato de que, neste estudo, não foi utilizado nenhum tipo de agente de união adesivo e também pela contração de polimerização apresentada pela resina composta quando não aplicada pela técnica incremental.

Um complexo estudo in vitro foi publicado por SHETH; FULLER; JENSEN ${ }^{98}$, em 1988, onde avaliaram a influência da utilização de diversos adesivos dentinários, na resistência à fratura de pré-molares superiores, além do grau de deformação das cúspides, como conseqüência da contração de polimerização do material restaurador. Dividiram-se 100 dentes em 10 grupos, sendo estes subdivididos em dois grupos de cinco dentes, que receberam preparos cavitários classe II (MOD) com 1/3 da distância intercuspídea e com 1/2 da dimensão vestíbulo-lingual (Figuras 13 e 14). Mediram-se os dentes antes e depois da realização dos preparos cavitários (L1- antes, L2- depois). Restauraram-se, então, os dentes que ficaram assim agrupados : grupo A - verniz copal e amálgama; grupo B - verniz no esmalte e adesivo Bondlite na dentina e resina composta; grupo $\mathrm{C}$ - verniz na dentina e adesivo Bondilite no esmalte e resina composta; grupo D - adesivo Bondilite no esmalte condicionado com ácido e dentina não condicionada e resina composta ; grupo E - adesivo 4-META no esmalte e dentina condicionados com ácido e resina 
composta. Realizaram-se novas medidas após 10 minutos (L3), 40 minutos (L4), 24 horas (L5) e 7 dias (L6), para se verificar a deflexão das cúspides. Submeteram-se os dentes a forças de compressão após uma semana em uma máquina de ensaios universal, utilizando-se uma esfera de aço de $5 \mathrm{~mm}$ de diâmetro e velocidade de 0,5 cm/min. Da análise dos resultados, pôde-se verificar uma expansão expressiva apenas no grupo A. Observou-se ainda que, nos subgrupos com preparos mais conservativos, não houve diferença estatisticamente significante independente dos procedimentos restauradores, mostrando resultados semelhantes aos apresentados pelos dentes hígidos. Nos subgrupos com cavidades extensas, verificou-se que, quando se utilizou o 4-META, se encontraram valores superiores, quando se comparou aos demais grupos.

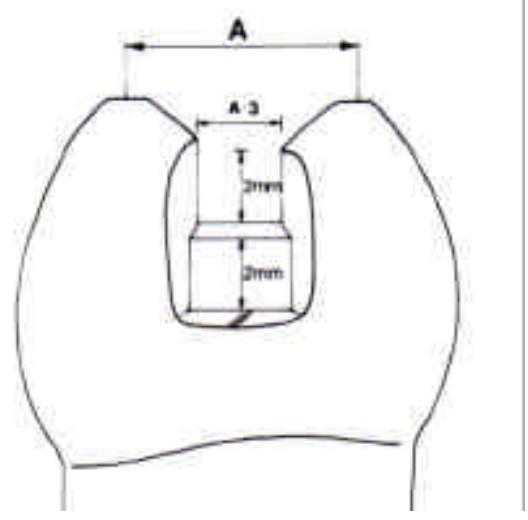

FIGURA 13 -Preparo cavitário reduzido com $1 / 3$ da distância intercuspídea ${ }^{98}$

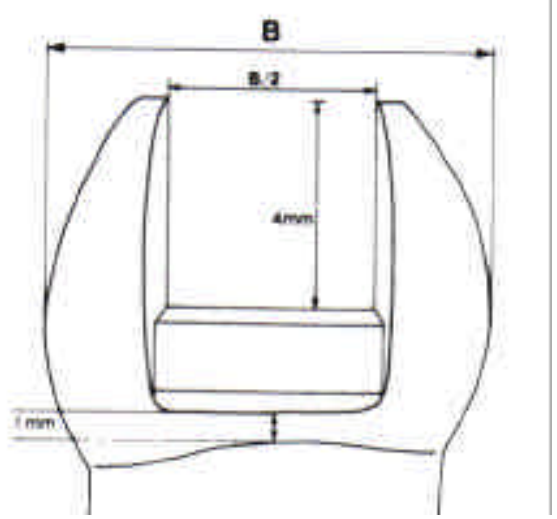

FIGURA 14 - Preparo cavitário amplo com $1 / 2$ da dimensão vestíbulolingual $^{98}$

Em 1988, EL-SHERIF et al. ${ }^{37}$ investigaram a resistência à fratura de dentes que receberam restaurações à amálgama. Para o estudo, selecionaram-se cem dentes pré-molares superiores hígidos, que foram divididos em dez grupos de dez 
dentes cada. O grupo 1 permaneceu hígido, não recebendo tratamento algum. Os demais receberam preparos cavitários, sendo três grupos com preparos tipo $\mathrm{MO}$; três grupos com preparo tipo DO; e três grupos com preparo tipo MOD. Realizaramse ainda variações nas dimensões da abertura do istmo da caixa oclusal com 1/4, 1/3 e 1/2 da distância intercuspídea. Restauram-se todos os dentes com amálgama e submeteram-se os corpos de prova a testes de resistência à fratura, sob ação de uma carga axial, em uma máquina de ensaios universal, através de uma esfera de aço acoplada, com 5,0 m.m. de diâmetro (não sendo mencionada a velocidade). Da análise dos resultados, não se encontrou diferença estatística significante nas amostras que receberam preparos tipo MOD e aqueles que receberam preparos tipo MO e DO, quando se comparou a mesma abertura de istmo. Verificou-se ainda que, quanto menor o istmo da caixa oclusal, maior a resistência à fratura, quando se compara com istmos mais amplos. Concluiu-se então que a abertura da caixa oclusal é um fator consideravelmente relevante no enfraquecimento do dente, recomendando-se a conservação da estrutura dentária sadia.

Um importante trabalho publicado por WIECZKOWSKI et al. ${ }^{117}$, em 1988, mostrou a comparação do efeito de duas técnicas de aplicação de resina composta na forma direta, na resistência à fratura de dentes com cúspide estruturalmente enfraquecidas. A primeira técnica consistia na aplicação de incremento único por caixa (Figura 15), já a segunda consistia em incrementos dispostos diagonalmente, os dois primeiros até a altura do ângulo áxio-pulpar e, os dois restantes, até a altura da crista marginal, totalizando dois incrementos por caixa (Figura 16). Preparos padronizados de classe II MOD com margens em esmalte foram realizados em prémolares humanos. Os dentes foram então restaurados de acordo com os seguintes 
materiais e técnicas: grupo 1 - resina composta P-30, técnica de incremento único (por caixa); grupo 2 - resina composta P-30, técnica incremental diagonal; grupo 3 resina composta Ful-fil, técnica de incremento único e grupo 4 - resina Ful-fil, técnica incremental diagonal. Após o acabamento das faces proximais com completa remoção dos excessos, os espécimes foram armazenados em água deionizada por 72 horas, antes dos testes de resistência à fratura em máquina de teste universal, que teve acoplado um dispositivo com dois cilindros com 1,985 mm de diâmetro, a uma velocidade de $0,01 \mathrm{~cm} / \mathrm{min}$., em contato somente com as vertentes de cúspide.

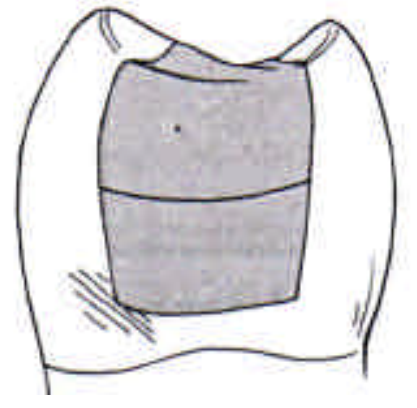

FIGURA 15 - Inserção da resina composta pela técnica do único incremento por caixa ${ }^{117}$

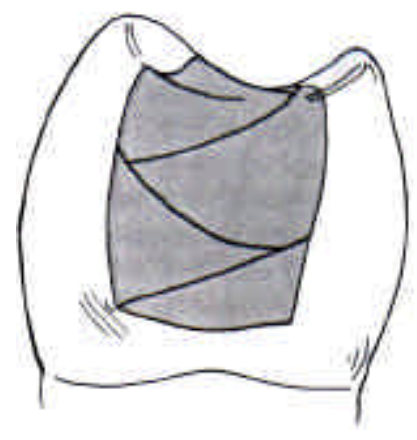

FIGURA 16 - Inserção da resina composta pela técnica incremental ${ }^{117}$

O estudo mostrou uma maior resistência à fratura de cúspides nos dentes restaurados pela técnica incremental do que naqueles restaurados pela técnica de incremento único (técnica recomendada pelos fabricantes).

REEL; MITCHELL ${ }^{92}$, em 1989, avaliaram o efeito da utilização de adesivos de dentina e de esmalte na resistência à fratura de dentes pré-molares superiores que receberam restaurações extensas de resina composta. Estes autores avaliaram 
ainda o efeito do tipo de cura do material (químico ou foto) e do preparo das margens (com e sem bisel). Selecionaram-se setenta dentes e dividiram-se em sete grupos, sendo o grupo A, o controle. Os demais grupos receberam preparos padronizados MOD, com profundidade de $3 \mathrm{~mm}$ e abertura de istmo, metade da distância intercuspídea (Figura 17).

FIGURA 17 - Dimensões dos preparos cavitários realizados $^{92}$

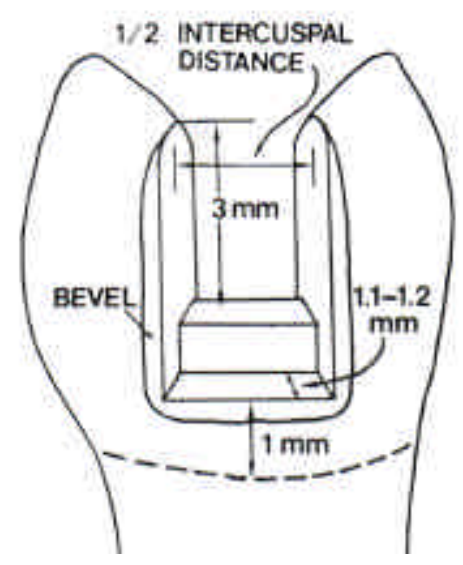

As caixas proximais tiveram a parede gengival a $1,0 \mathrm{~mm}$ da junção cementoesmalte, com profundidade de 1,1 a 1,2 $\mathrm{mm}$.

Os grupos foram assim constituídos:

A - controle (sem qualquer tratamento);

B - dentes preparados, não restaurados;

C - dentes preparados/ biselados/ adesivo de esmalte (Concise

Enamel Bond/ resina química Concise (3M);

D - dentes preparados/ sem bisel/ adesivo de esmalte Concise

Enamel Bond/ resina química Concise (3M);

S - dentes preparados/ biselados/ adesivo dentinário Scotchbond 
$3 \mathrm{M} /$ resina química Concise $(3 \mathrm{M})$;

$\mathrm{J}$ - dentes preparados/ biselados/ adesivo dentinário Dentinal

Bonding agent $(\mathrm{J} \& \mathrm{~J}) /$ resina fotopolimerizável Certain (J\&J);

$\mathrm{V}$ - dentes preparados/ biselados/ adesivo dentinário Dentin-

Adhesit (Vivadent)/ resina fotopolimerizável Certain (J\&J).

Submeteram-se os corpos de prova a testes de compressão com uma esfera metálica com um diâmetro de 4,7 mm em contato com as vertentes de cúspide, a uma velocidade de $0,508 \mathrm{~m} . \mathrm{m} . / \mathrm{min}$, até que houvesse fratura. Os resultados mostraram que os dentes restaurados tiveram uma resistência à fratura de metade dos valores do grupo controle, independente do adesivo utilizado e da presença ou não do bisel. Não houve diferença estatística quando se comparou o tipo de adesivo utilizado nem entre a presença e a ausência de bisel.

A resistência à fratura de dentes restaurados com amálgama e resina composta fotopolimerizável também foi comparada por JAGADISH; YOGESH ${ }^{57} \mathrm{em}$ 1990, que compararam ainda a um grupo restaurado com ionômero de vidro reforçado. Foram avaliados quarenta dentes pré molares que receberam preparos cavitários classe II, MO ou DO. Os grupos com preparos cavitários apresentavam istmo em torno de 1,5 a 1,7 m.m.. Dividiram-se os dentes em cinco grupos que receberam os seguintes tratamentos:

Grupo 1 : dentes hígidos (5 dentes);

Grupo 2 : cavidades classe II / sem restauração (5 dentes);

Grupo 3 : cavidades classe II / amálgama (10 dentes);

Grupo 4 : cavidades classe II / condicionamento ácido/ adesivo dentinário/ resina composta (10 dentes); 
Grupo 5 : cavidades classe II / ionômero "cermet” (10 dentes).

Submeteram-se os dentes a teste de carregamento axial, com um dispositivo acoplado à maquina de ensaios com dois cilindros de $2 \mathrm{~cm}$ de diâmetro cada (Figura 18), a uma velocidade de $0,1 \mathrm{~mm} / \mathrm{seg}$, em contato com as vertentes de cúspide.

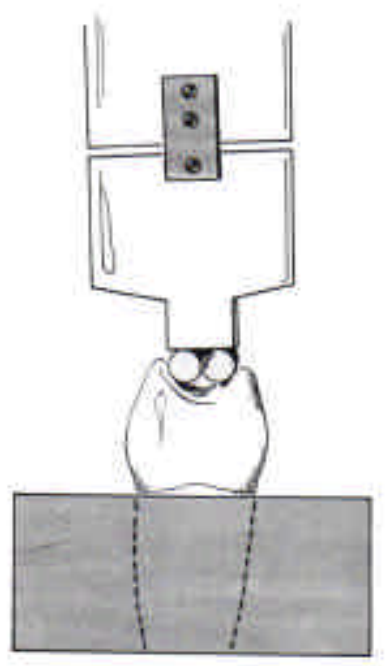

FIGURA 18 - Teste de compressão axial realizado através de duas barras metálicas ${ }^{57}$

Os dentes do grupo 2, ou seja, que receberam preparo cavitário e que não foram restaurados, apresentaram as menores médias de resistência à fratura. As médias apresentadas pelo grupo que recebeu preparo cavitário e restauração de resina composta fotopolimerizável $(256,33 \mathrm{~kg})$ foram superiores à média apresentada pelo grupo de dentes hígidos $(187,24 \mathrm{~kg})$, mostrando então o restabelecimento da resistência à fratura. Os dentes que receberam restaurações de ionômero tipo "cermet", apresentaram resultados superiores ao grupo controle $(217,64 \mathrm{~kg})$, mas sem que houvesse diferença estatisticamente significante. Os dentes restaurados 
com amálgama apresentaram valores $(169,41 \mathrm{~kg})$ ligeiramente menores que o grupo-controle, porém sem diferença estatística. Afirmou-se que a obtenção destes resultados foi devido à preservação da crista marginal, estrutura importante para a resistência à fratura dos dentes, além de fornecer uma área adicional de adesão para o material restaurador.

Em 1990, DIETSCHI et al. ${ }^{32}$ propuseram avaliar a resistência à fratura de restaurações indiretas de dois materiais cerâmicos, verificando-se a influência da incorporação de óxido de alumínio no material cerâmico e a influência do cimento utilizado. Selecionaram-se sessenta terceiros molares que foram divididos em seis grupos de dez dentes cada, sendo o grupo 1 o controle, que permaneceram hígidos, sem qualquer tratamento. Os demais grupos receberam preparos cavitários tipo MOD que tinham 2,5 $\mathrm{mm}$ de profundidade e de largura de istmo da caixa oclusal, sendo que a caixa proximal tinha uma abertura de 4 mm (Figuras 19 e 20).

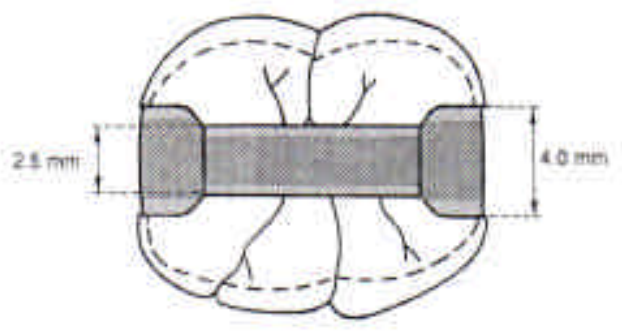

FIGURA 19 - Dimensões dos preparos $^{32}$

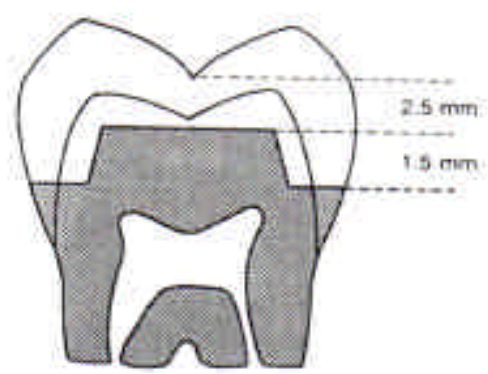

FIGURA 20 - Profundidade e extensão dos preparos $^{32}$ 
Os grupos ficaram assim definidos:

Grupo 1 - controle, dentes hígidos;

Grupo 2 - cerâmica Vitadur N, reforçada com óxido de alumina/ cimento resinoso;

Grupo 3 - cerâmica Vitadur N/ cimento resinoso;

Grupo 4 - cerâmica Ceranco II/ cimento resinoso;

Grupo 5 - cerâmica Vitadur N/ cimento de ionômero de vidro;

Grupo 6 - cerâmica Ceranco II/ cimento de ionômero de vidro.

Todas as restaurações receberam tratamento interno de superfície, através do condicionamento com ácido hidrofluorídrico a $40 \%$, por três minutos. As restaurações dos grupos 2, 3 e 4 foram também silanizadas após a aplicação do ácido, previamente à cimentação. Os dentes, por sua vez, receberam condicionamento ácido do esmalte, não havendo a aplicação de nenhum agente de união resinoso ou de adesivo. Realizaram-se, então, os testes de carregamento axial, utilizando-se uma esfera de $2 \mathrm{~mm}$ de diâmetro a uma velocidade de $1 \mathrm{~mm} / \mathrm{min}$, que foi aplicada na superfície oclusal até que ocorresse a fratura. As médias apresentadas pelos grupos foram menores que as do grupo controle. O grupo 2 foi o que apresentou as maiores médias $(273,5 \mathrm{~kg})$ que corresponderam a cerca de $75 \%$ da resistência apresentada pelo grupo 1. O grupo 6 foi o que apresentou os menores resultados $(145,4 \mathrm{~kg})$. Os resultados apresentados pelos demais grupos foram: grupo 1, 363 kg; grupo 3, 206,2 kg; grupo 4, 169,5 kg; grupo 5, 158,2 kg. Quando se compararam, então, os resultados entre os tipos de cerâmica, a Vitadur $\mathrm{N}$ teve melhor comportamento que a Ceranco II, e verificou-se ainda que o cimento resinoso 
teve melhor desempenho que o cimento de ionômero de vidro, apesar de não se encontrar diferenças estatísticas nos dois casos.

A influência da técnica do condicionamento ácido, associado às restaurações de resina composta fotopolimerizáveis na resistência à fratura de pré-molares foi estudada por LIBERMAN et al. ${ }^{66}$, que, em 1990, publicaram um trabalho onde apresentaram os resultados comparando a dentes restaurados com restaurações a amálgama. Selecionaram-se 30 dentes hígidos, superiores e inferiores, que foram divididos em 3 grupos que receberam preparos cavitários classe II, MOD, conferindo-se paredes vestibular e lingual com uma espessura de $2 \mathrm{~mm}$ e com profundidade de $4 \mathrm{~mm}$, tendo a parede axial 1,5 $\mathrm{mm}$ de profundidade. $\mathrm{O}$ grupo 1, controle, não recebeu restauração, sendo que o grupo 2 recebeu restaurações a amálgama e o grupo 3, restaurações com resina composta (P-30) pela técnica incremental, sendo previamente condicionados com ácido em esmalte, após o qual aplicou-se adesivo em esmalte e dentina (Scotchbond -3M). Submeteram-se os corpos de prova a testes de compressão axial, direcionada sobre as pontas de cúspides (uma de cada vez), em uma máquina de ensaios universal, utilizando-se uma esfera de metal numa velocidade de $0.5 \mathrm{~cm} / \mathrm{min}$. até que ocorresse a fratura. Verificou-se que os dentes restaurados com resina composta apresentaram valores significantemente maiores quando comparados com os dentes restaurados com amálgama e com o grupo-controle, devido às ligações mecânicas e químicas das resinas à estrutura dentária (esmalte e dentina).

Em 1991, foi publicado um artigo no qual estudou-se o papel de restaurações indiretas de resina composta no reforço de cúspides enfraquecida por extensos preparos cavitários intracoronários através de testes não destrutivos, de 
carregamento axial. Para isso, LOPES et al. ${ }^{67}$ avaliaram nove dentes pré-molares superiores extraídos, hígidos, que tiveram aderidos à superfície vestibular e lingual um medidor de tensão. Este registrava a flexão das cúspides quando submetidas à carga axial de forma cuidadosa e controlada. Foram feitas medições nos dentes quando hígidos, preparados e restaurados, comparando-se com a força funcional máxima dos dentes íntegros que era de 111 N. O tipo de preparo cavitário executado foi MOD, sem proteção de cúspide, com abertura de istmo oclusal de metade da distância intercuspídea. Foram confeccionadas restaurações parciais indiretas de resina composta, cimentando-as com cimento resinoso tipo dual, sendo que os dentes receberam tratamento de superfície, previamente à cimentação que consistiu em se aplicar uma fina camada de cimento de ionômero de vidro e a realização de condicionamento ácido em esmalte e aplicação de um sistema adesivo. Verificou-se, através dos resultados, que os dentes previamente à restauração, quando submetidos à carga axial, apresentaram grande deflexão cuspídea, no sentido de se separar as cúspides, mostrando uma rigidez de $33 \%$ mostrada pelos dentes quando hígidos. Quando se avaliaram os dentes já restaurados, observou-se um aumento na rigidez dos dentes, obtendo-se um valor de $97 \%$ da rigidez inicial, com uma tendência à deflexão de cúspide em direção a um dos lados, ou seja, para vestibular ou para lingual, evidenciando-se a capacidade da restauração em manter as cúspides unidas, sem a tendência à separação das mesmas (Figuras 21 e 22). Do ponto de vista da resistência das cúspides, isto significa que, para extensas cavidades, onde as cúspides estão enfraquecidas, estariam indicadas restaurações intracoronárias, e que, apesar de alguns fatores, como o tempo operatório e a complexidade, algumas das propriedades do material 
foram melhoradas, e como todo procedimento restaurador, apresenta vantagens e desvantagens.
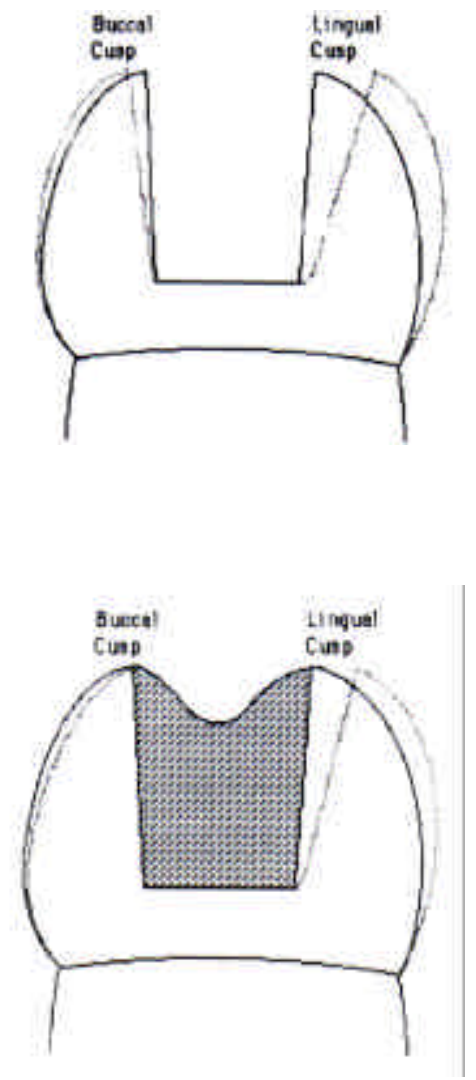

FIGURA 21 - Flexão das

cúspides em direções opostas $^{67}$

FIGURA 22 - As cúspides defletem na mesma direção ${ }^{67}$

$H O O D^{54}$, em 1991, publicou um interessante trabalho onde se descreveu a biomecânica dos preparos classe II e a ação das forças mastigatórias sobre a estrutura dentária que recebeu este tipo de preparo cavitário. Substituições freqüentes de restaurações fazem com que o dente fique enfraquecido, devido ao aumento da profundidade da cavidade, que leva ao aumento da altura das cúspides, além do aumento da amplitude do istmo. A realização deste tipo de preparo faz com que as cúspides se comportem como um "cantilever" (Figura 23), que, sob ação 
das forças mastigatórias induziriam estresse nos ângulos internos da cavidade, levando à fratura. Relatou-se ainda, que as restaurações intracoronárias a amálgama ou resina composta, sem a realização de condicionamento ácido, não possibilitam o reforço da estrutura dentária remanescente, o que ocorre quando da realização de restaurações adesivas, apesar de haver uma fadiga progressiva na interface de união, o que causaria sensibilidade pós-operatória. Evidenciou-se que, embora nas restaurações indiretas de resina composta ou cerâmica, haja uma contração de polimerização mínima, restrita ao cimento resinoso, os mecanismos de união falham também devido à fadiga. Enfatizou-se que os dentes com cavidades extensas de classe II, MOD, deveriam ter as cúspides enfraquecidas envolvidas nos preparos extracoronários, o que aumentaria a rigidez relativa dos preparos cavitários a níveis próximos ou maiores que os dentes hígidos.

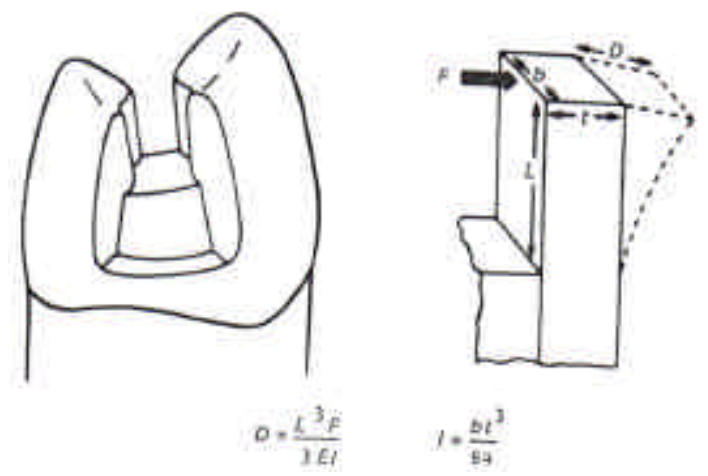

FIGURA 23 - Comparação entre a deflexão de um simples "cantilever" e um preparo classe II MOD ${ }^{54}$

Em 1993, BURKE; WILSON; WATTS $^{21}$ avaliaram o efeito da inclinação das paredes vestibular e lingual de cavidades na resistência à fratura de dentes pré-molares que receberam preparos MOD, e que foram restaurados com resina composta indireta. Dividiram-se os dentes em quatro grupos de 10 dentes 
cada, analisando-se as inclinações de $2^{\circ}, 4^{\circ}$ e $6^{\circ}$ além de um grupo que não recebeu qualquer tipo de tratamento. Submeteram-se os corpos de prova à ensaios de carregamento axial, em uma máquina regulada a uma velocidade de $1 \mathrm{~mm} . / \mathrm{min}$. Os grupos foram subdivididos, sendo, então, realizado nos subgrupos $A(1,2$ e 3$)$, teste de compressão com uma esfera de aço de $4 \mathrm{~mm}$ de diâmetro e, nos subgrupos B (1, 2 e 3), com um cilindro de aço de mesma dimensão. O padrão de fratura foi analisado, seguindo-se a classificação descrita na Figura 24.

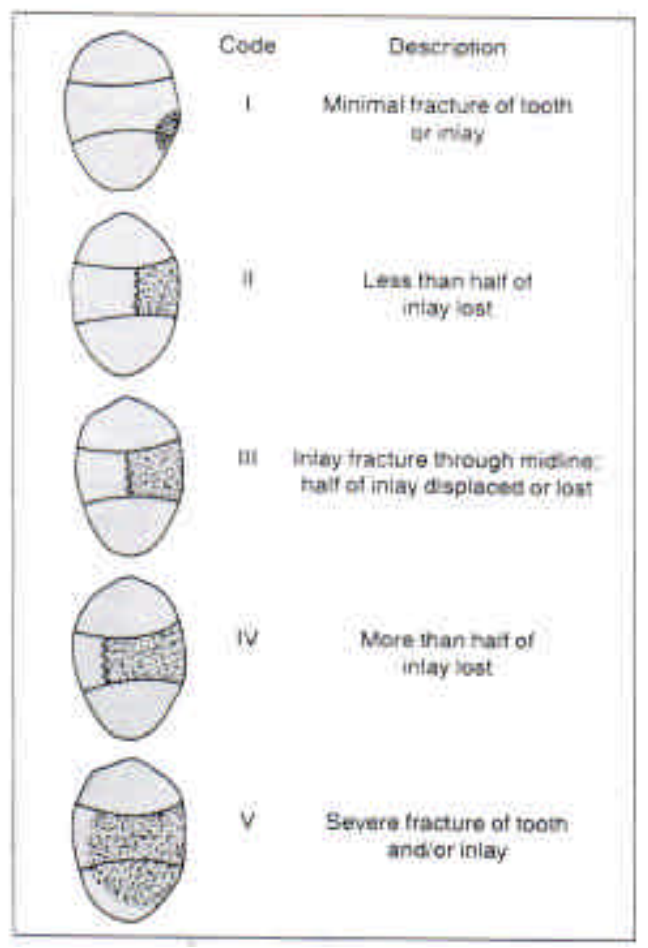

FIGURA 24 - Padrões de fratura descritos de acordo com o grau de severidade $^{21}$

As médias dos valores destes grupos foram comparadas com as médias dos valores de dois subgrupos controle (A e B), que foram de dentes hígidos. Nenhum dos grupos que recebeu restaurações indiretas de resina composta mostrou resistência à fratura como observada no grupo controle, encontrando-se valores de 
até $60 \%$. Não se encontrou ainda diferença estatisticamente significante entre os grupos que receberam restaurações, onde se variou a inclinação das paredes vestibular e lingual da caixa oclusal em $2^{\circ}, 4^{\circ}$ e $6^{\circ}$, apesar deste último apresentar um padrão de fratura mais severo. Observou-se ainda que, no grupo com menor inclinação nas paredes $\left(2^{\circ}\right)$, houve uma maior dificuldade de adaptação das restaurações aos preparos cavitários. Dentre as três inclinações utilizadas, $4^{\circ}$ parece ser a que melhor favorece a realização dos procedimentos laboratoriais e clínicos e a menor ocorrência de casos severos de fratura quando sob ação de carga. Comparando-se os resultados entre o método de realização dos testes, não se encontraram diferenças nos valores obtidos, mas quando da utilização da esfera, houve uma maior dificuldade na manutenção da mesma em posição, o que foi facilmente obtido quando da utilização do cilindro, que apresentou ocorrência de fraturas mais severas, havendo menor semelhança a um dente antagonista, do que quando se utiliza a esfera.

Uma série de trabalhos publicados por pesquisadores ingleses, liderados por BURKE foram publicados a partir de 1994, onde, através de trabalhos seqüenciais e complementares $^{16,18,19,70}$, se avaliou a resistência à fratura de dentes pré-molares, restaurados com diversos materiais, seguindo-se a mesma metodologia de pesquisa. No primeiro deles (BURKE; WATTS ${ }^{18}$ ), foram realizados preparos totais em 20 dentes pré-molares superiores nos quais se confeccionaram preparos com inclinação de 6 (grupo 1) e $8^{\circ}$ (grupo 2) para, então, receberem coroas ocas de porcelana (Mirage) que foram cimentadas com cimento resinoso e submetidas a testes de compressão através da utilização de uma barra de aço de $4 \mathrm{~mm}$ de diâmetro, a uma velocidade de $1 \mathrm{~mm} / \mathrm{min}$. até que a fratura ocorresse. Um grupo de 
10 dentes foi o controle, de hígidos. O resultado apresentado pelo grupo 1 foi de 78,51 kgf, enquanto que o grupo foi de 72,40. Já o grupo-controle apresentou resultados de 98,90, não havendo diferença estatística entre este e o controle.

$\mathrm{Na}$ seqüência de trabalhos deste grupo de pesquisadores ingleses, foi o publicado por MAK; QUALTROUGH; BURKE ${ }^{70}$, que, em 1997, compararam a resistência à fratura de dentes pré-molares, e estes receberam preparos cavitários e foram restaurados com coroas ocas de porcelana. Os grupos foram divididos em:

grupo 1 - porcelana feldspática da marca comercial Mirage;

grupo 2 - vidro ceramizado da marca comercial IPS Empress;

grupo 3 - cerâmica infiltrada de vidro da marca comercial Dicor e

grupo 4 - porcelana aluminizada da marca comercial Vitadur N.

Após os procedimentos restauradores, realizaram-se os testes de resistência, através da utilização de uma barra de aço de $4 \mathrm{~mm}$ de diâmetro, aplicada no sulco central dos dentes, numa velocidade de $1 \mathrm{~mm} / \mathrm{min}$. $\mathrm{O}$ padrão de fratura também foi anotado. Constatou-se que os grupos restaurados com Dicor e com IPS Empress apresentaram as maiores médias, respectivamente 114,20 e 96,90 kgf, valores significantemente maiores que a média apresentada pelos demais grupos. O padrão de fratura apresentado pelo grupo restaurado com IPS Empress apresentou os padrões mais severos (modo V), possivelmente pela maior transmissão das forças à estrutura dentária, sendo que $60 \%$ das fraturas não envolveram a porcelana, mas sim na interface dente-agente cimentante, e nenhuma na interface cerâmica-agente cimentante. Este padrão apresentado se deve ao fato de a adesão obtida por este material restaurador ter sido maior que nos outros grupos. A cerâmica Dicor é que 
apresentou a performance mais satisfatória, apresentando os mais altos valores de resistência com baixa porcentagem de envolvimento da estrutura dentária.

Na mesma linha de pesquisa, BURKE; WATTS $^{19}$, publicaram, em 1998, os resultados obtidos ao investigarem o efeito da combinação de diferentes sistemas adesivos e de cimentação na resistência à fratura de dentes restaurados com coroas puras de porcelana. Selecionaram-se cinqüenta dentes pré-molares hígidos, que foram divididos em cinco grupos de dez dentes cada. Realizaram-se preparos cavitários padronizados com redução oclusal de 2,0 mm e desgaste axial de 2,0 mm com 6 graus de inclinação, eliminando-se todas as convexidades, e um término marginal em ombro de $0,5 \mathrm{~mm}$ de profundidade. Confeccionaram-se as restaurações de cerâmica pura, que tiveram a superfície interna tratada com ácido hidrofluorídrico e foram então cimentadas de acordo com as seguintes combinações:

Grupo A- Mirage ABC / Mirage FLC

Grupo B- Metabond

Grupo C- All-Bond 2 / Duo-Link

Grupo D- Scotchbond MP Plus / 3M Indirect Porcelain Bonding Kit

Grupo E- All-Bond 2 / 3M Indirect Porcelain Bonding Kit.

Submeteram-se os corpos de prova a testes de compressão axial, através de um cilindro de aço com $4 \mathrm{~mm}$ de diâmetro, a uma velocidade de 1,0 mm/min. A média dos resultados obtidos foram os seguintes: grupo A, 78,51 kgf; grupo B, 82,59 kgf; grupo C, 72,39 kgf; grupo D, 125,42 kgf e Grupo E, 105,02 kgf. A análise estatística dos resultados mostrou que os resultados obtidos pelos grupos $D$ e $E$ foram significantemente maiores que o dos demais grupos, concluindo-se que a resistência à fratura de dentes restaurados com restaurações adesivas de cerâmica pura é 
dependente dos sistemas adesivos e de cimentação utilizados. As propriedades físicas do cimento resinoso Indirect Porcelain Bonding Kit (3M) devem ser responsáveis pelos valores estatisticamente maiores apresentados por estes grupos, e que, quando da utilização do sistema adesivo de mesmo fabricante, houve um maior sinergismo entre restauração, o sistema adesivo/cimento resinoso e dente.

$B U R K E^{16}$, em 1999, investigou a resistência à fratura in vitro, em 10 dentes pré-molares superiores que receberam preparos totais e restaurações de cerâmica IPS Empress - Ivoclar, complementando-se trabalhos realizados anteriormente, quando se compararam diferentes materiais restauradores e sistemas adesivos em associação com diversos cimentos resinosos ${ }^{18,19,70}$. No presente estudo, utilizou-se sistema adesivo Scotchbond MP Plus (3M) e Indirect Porcelain Bonding Kit, do mesmo fabricante. A média dos resultados obtidos quando da realização de testes de compressão (cilindro de aço de $4 \mathrm{~mm}$, velocidade de $1 \mathrm{~mm} / \mathrm{min}$.) foi de 170,28 kgf $( \pm 40,78)$, apesar de apresentar um risco de $30 \%$ de fraturas catastróficas, podendo não haver possibilidade de recuperação do dente quando isso ocorrer clinicamente.

Avaliou-se a influência da largura e profundidade dos preparos de cavidade, na resistência à fratura de dentes restaurados com resina composta confeccionada por técnica indireta. WATTS et al. ${ }^{114}$ em 1995, selecionaram cinqüenta pré molares superiores, dividindo-os em 5 grupos de dez amostras cada. O grupo 1 foi o controle, não recebendo qualquer tipo de tratamento. Realizaram-se cavidades tipo MOD, sem proteção de cúspide, em quatro grupos, variando-se as dimensões das cavidades, assim:

$\begin{array}{ccc}\text { Grupo } & \text { Largura da cavidade } & \text { Profundidade } \\ 2 & 1 / 3 \text { da dist. V.L. } & 4 \mathrm{~mm}\end{array}$




$\begin{array}{lll}3 & 1 / 2 \text { da dist. V. L. } & 4 \mathrm{~mm} \\ 4 & 1 / 3 \text { da dist. V. L. } & 3 \mathrm{~mm} \\ 5 & 1 / 3 \text { da dist. V. L. } & 5 \mathrm{~mm}\end{array}$

Padronizaram-se as caixas proximais em todos os preparos, sendo que a profundidade era de $2 \mathrm{~mm}$; e a largura vestíbulo lingual igual à metade desta medida. Duplicaram-se os preparos com moldes de silicona de adição, obtendo-se troquéis de gesso onde confeccionaram-se as restaurações. Realizou-se condicionamento ácido dos dentes e cimentaram-se as restaurações com o mesmo cimento resinoso. Após um período mínimo de quatro horas, submeteram-se os corpos de prova a testes de compressão em uma máquina de ensaio universal, com uma barra de aço de $4 \mathrm{~mm}$ de diâmetro, a uma velocidade de $1 \mathrm{~mm} / \mathrm{min}$., em contato com a superfície oclusal. As médias dos valores apresentados foram (em kgf): grupo 1: $98,90 \pm 20,39$; grupo 2: $61,18 \pm 12,23$; grupo 3: $73,41 \pm 11,21$; grupo 4: $60,16 \pm 12,23$; grupo 5: $44,86 \pm 10,19$. Da análise estatística dos resultados, constatou-se que não houve um restabelecimento da resistência à fratura nos dentes restaurados com resina composta pela técnica indireta. Observou-se ainda que, quanto maior a largura e a profundidade das cavidades, menor a resistência à fratura, mesmo em preparos mais conservativos. Preparos com 3 a $4 \mathrm{~mm}$ de profundidade seriam os mais indicados, mas, quando a prevalência do modo de fratura foi avaliada, os dentes com preparos mais conservativos apresentaram menor severidade.

Uma série de considerações a respeito dos tipos de cimentos utilizados para cimentação de restaurações cerâmicas foi pesquisado por $B U R K E^{14}$ em 1995. Neste estudo, este autor comparou a resistência à fratura de dentes restaurados com 
coroas totais puras de cerâmica, cimentadas com cimento resinoso associado a sistemas adesivos e ainda cimentadas com cimento de fosfato de zinco. Foram selecionados quarenta pré-molares superiores, sendo divididos em quatro grupos. Realizaram-se preparos cavitários padronizados para coroas totais, reduzindo-se 2,0 $\mathrm{mm}$ na oclusal, $1,0 \mathrm{~mm}$ na axial, que teve uma inclinação de $6^{\circ}$ e término em forma de ombro de 0,5 mm de largura. Confeccionaram-se as restaurações cerâmicas, sendo que, nos grupos 1 e 3 , foi realizado tratamento da superfície interna com ácido hidrofluorídrico e silano. Cimentaram-se as restaurações nos grupos 1, 2 e 3 com cimento resinoso, e as restaurações do grupo 4 foram cimentadas com cimento de fosfato de zinco. Os dentes dos grupos 1 e 2 foram condicionados com ácido e receberam aplicação do sistema adesivo. Submeteram-se os exemplares à carga de compressão axial, utilizando-se uma barra metálica de $4 \mathrm{~mm}$ de diâmetro, a uma velocidade de $1 \mathrm{~mm} / \mathrm{min}$., aplicada na fossa central dos pré-molares; e os resultados mostraram que a média de resistência à fratura dos grupos 1 e 2 apresentaram resultados significantemente maiores que os do grupo 4 . O grupo 3 apresentou uma média menor que a dos grupos 1 e 2, não se encontrando diferença estatisticamente significante. Pode-se concluir, de forma geral, que há um melhor sinergismo no conjunto dente/restauração quando se associam cimentos resinosos com sistemas adesivos quando sujeitos à cargas de compressão, sendo que o cimento teve um papel fundamental, aumentando a resistência à fratura, devido às suas propriedades físicas melhoradas e pela prevenção da propagação de pequenas rachaduras.

Em outro trabalho de $B \boldsymbol{R} K \boldsymbol{K}^{15}$, publicado em 1996, foi estudado o efeito de variações realizadas nos preparos cavitários na resistência à fratura de dentes restaurados com coroas ocas de cerâmica, cimentadas com cimento resinoso 
seguido do condicionamento ácido e da aplicação dos sistemas adesivos. Selecionaram-se quarenta pré molares superiores hígidos, dividindo-os em quatro grupos, que foram assim constituídos de acordo com as variações nas dimensões no preparo : grupo A, recebeu preparos com desgaste oclusal de 2,0 mm, redução axial de $1,0 \mathrm{~mm}$, inclinação das paredes axiais de $6^{\circ}$ e término cervical em "lâmina de faca"; grupo B, recebeu preparos com redução oclusal de $3,0 \mathrm{~mm}$, inclinação das paredes axiais de $6^{\circ}$ e término em ombro de $1,0 \mathrm{~mm}$ de largura; grupo $\mathrm{C}$, desgaste semelhante ao do grupo $B$, havendo uma redução oclusal de 2,0 $\mathrm{mm}$ somente nas cúspides vestibulares; grupo $\mathrm{D}$, também semelhante ao do grupo $\mathrm{B}$, mas com desgaste oclusal de 2,0 mm em todas as cúspides. Confeccionaram-se coroas puras de porcelana que foram cimentadas utilizando-se o mesmo cimento resinoso em associação aos sistemas adesivos em todos os grupos. Submeteram-se os dentes a carregamento axial em uma máquina de ensaios universal, que teve acoplada um cilindro de aço com $4 \mathrm{~mm}$ de diâmetro, a uma velocidade de $1 \mathrm{~mm} / \mathrm{min}$. Observaramse os seguintes resultados: grupo A, 78,51 kgf; grupo B, 100,94 kgf; grupo C, 95,71 kgf e grupo D, 79,53 kgf. Da análise estatística dos resultados, verificou-se que não houve diferença significante entre os grupos, concluindo-se que o aumento de 2,0 $\mathrm{mm}$ para 3,0 mm no desgaste oclusal, utilizando-se término em ombro, ao invés de "lâmina de faca", não houve um aumento da resistência à fratura em restaurações tipo coroas puras de cerâmica, além de haver um aumento do potencial de dano à polpa. Preparos conservativos provêem boa resistência à fratura e ótima estética, devendo ter ângulos arredondados, para prevenir a concentração de forças na restauração e cerca de $6^{\circ}$ de inclinação das paredes axiais, além de lançar mão de 
cimentos resinosos e de sistemas adesivos para superar a diminuição das retenções que eram realizadas nos preparos tradicionais.

Em 1998, OLIVEIRA ${ }^{83}$ realizou um trabalho de dissertação onde descreveu a avaliação comparativa da resistência à fratura de dentes restaurados com restaurações parciais indiretas de polímero de vidro, resina composta e cerâmica. Selecionaram-se quarenta pré-molares superiores e dividiram-se em 5 grupos de oito amostras cada, assim: grupo I , que não recebeu nenhum tipo de tratamento, enquanto que os demais receberam preparos cavitários tipo MOD, sem proteção de cúspide (Figuras 25 e 26), sendo que os exemplares do grupo II não receberam nenhum tipo de restauração, enquanto que o grupo III foi restaurado com restaurações de polímero de vidro (Artglass), o grupo IV foi restaurado com resina composta (Solidex) e o grupo V , restaurações de cerâmica (Vitadur-Alpha).

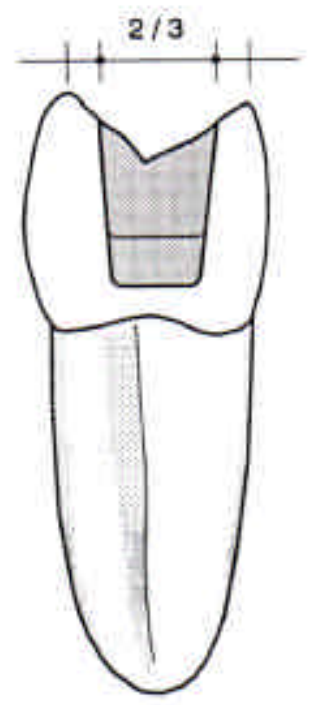

FIGURA 25 - Dimensões dos preparos $^{83}$

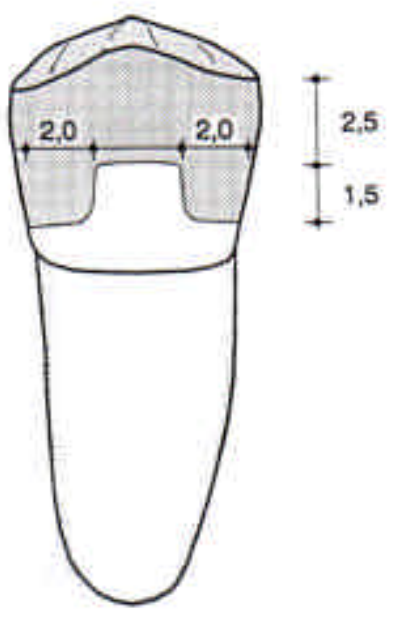

FIGURA 26 - Profundidade e extensão dos preparos $^{83}$ 
Todas as restaurações foram cimentadas com o mesmo cimento resinoso após o condicionamento ácido total e a aplicação dos sistemas adesivos. Os exemplares dos cinco grupos foram submetidos à ação de uma carga de compressão axial, utilizando-se de uma máquina de ensaio universal, com um cilindro de 12,0 $\mathrm{mm}$ na extremidade em contato com as vertentes de cúspide, a uma velocidade de 1 mm/min. A média dos valores obtida pelos grupos foi: grupo I, 127,61 kgf; grupo II, 65,35 kgf; grupo III, 114,18 kgf; grupo IV, 114,06 kgf; grupo V, 110,51 kgf. Da análise dos resultados, pôde-se verificar que não houve diferença estatística significante entre o grupo de dentes hígidos (grupo I) e os grupos que receberam restaurações (grupos III, IV e V ). Os resultados apresentados pelo grupo II foram significantemente menores do que os demais grupos. Pôde-se concluir que, dentes grandemente enfraquecidos por preparos intracoronários extensos podem ter sua rigidez inicial restabelecida através de procedimentos e materiais restauradores que possuam capacidade adesiva.

BRUNTON et al. ${ }^{11}$, em 1999, propuseram avaliar a resistência à fratura de dentes pré-molares que receberam preparos padronizados e foram restaurados com 3 materiais restauradores. Foram selecionados quarenta dentes que foram divididos em quatro grupos de 10 dentes cada, sendo que um grupo (D) foi selecionado como controle, cujos dentes permaneceram intactos. Os demais grupos receberam preparos para restaurações tipo "onlay", sendo, então, realizados troquéis de gesso após a moldagem com silicona de condensação, confeccionando-se restaurações com resina composta Belle Glass - Kerr (grupo A), com resina composta SR Isosit (grupo B) e cerâmica IPS Empress - Ivoclar (grupo C). Os grupos B e C foram cimentados com cimento resinoso Variolink II em associação com sistema adesivo 
Syntac e o grupo A foi cimentado com cimento resinoso e sistema adesivo Nexus (Kerr). Após os procedimentos de restauração, os exemplares foram submetidos a testes de compressão numa máquina de ensaios que teve um cilindro de aço de 4 $\mathrm{mm}$ de diâmetro adaptado a uma velocidade de $1 \mathrm{~m} . \mathrm{m} . / \mathrm{min}$. As médias apresentadas pelos grupos foram: grupo A, 100,94 $\pm 57,10 \mathrm{kgf}$; grupo B, 159,07 \pm 55,06 kgf; grupo C, 100,94 \pm 49,96 kgf; grupo D, 111,14 \pm 31,61 kgf. Observou-se que os dentes restaurados com restaurações indiretas de resina composta mostraram valores maiores de resistência quando comparados a dentes restaurados com restaurações indiretas de resina composta fibro-reforçadas e com restaurações indiretas de cerâmica. As restaurações de resina composta apresentam maior flexibilidade e menor rigidez, conferindo ao dente uma inerente habilidade de flexão quando sob ação de forças oclusais. Por outro lado, as resinas fibro-reforçadas apresentam um modo de fracasso menos desastroso, quando comparadas à outra resina composta utilizada e, em relação às restaurações de cerâmica, que impossibilitam a propagação de trincas, além de poder ser clinicamente reparável. 


\section{PROPOSIÇÃO}




\section{3 - PROPOSIÇÃO}

Este trabalho se propõe a avaliar a resistência à fratura de dentes prémolares superiores, humanos, recém-extraídos, hígidos, que receberam preparos cavitários classe II, tipo MOD, e foram restaurados com restaurações intracoronárias adesivas diretas e indiretas de resina composta e restaurações intracoronárias adesivas de porcelana, através de testes de compressão axial in vitro.

Assim, os grupos serão avaliados nas seguintes condições:

Grupo 1 Controle, permaneceram sem qualquer tratamento

Grupo 2 Dentes com preparos cavitários classe II M.O.D., com paredes convergentes, não restaurados;

Grupo 3 Dentes com preparos cavitários classe II M.O.D., com paredes divergentes, não restaurados;

Grupo 4 Preparos idênticos ao grupo 2, restaurados com resina composta direta (Single Bond 3M/ Filtek Z 250 3M);

Grupo 5 Preparos idênticos ao grupo 3, restaurados com resina composta indireta (Single Bond 3M/ Rely X ARC 3M/ Artglass - Kulzer);

Grupo 6 Preparos idênticos ao grupo 3, restaurados com resina composta indireta (Single Bond 3M/ Rely X ARC 3M/ Targis - Ivoclar); 
Grupo 7 Preparos idênticos ao grupo 3, restaurados com porcelana (Single Bond 3M/ Rely X ARC 3M/ IPS Empress - Ivoclar). 
MATERIAL E MÉTODOS 


\section{4 - MATERIAL E MÉTODOS}

Os dentes utilizados no presente estudo foram pré-molares superiores hígidos, recém extraídos por motivos ortodônticos, coletados e armazenados em solução de formalina ${ }^{118}$. Realizou-se a limpeza dos mesmos através da realização de raspagem, associados à utilização de pedra pomes e água que foram aplicadas através da utilização de escova de Robson. Fixaram-se por mais 72 horas, na mesma solução, evitando-se assim a possível decomposição do tecido pulpar, sendo então armazenados após este período em timol a $0,1 \%{ }^{93}$ à temperatura ambiente. Todos os dentes foram analisados quanto à forma, além de serem examinados em lupa binocular (de magnitude 10X) para se avaliar ausência de trincas, rachaduras ou anomalias de esmalte. As dimensões vestíbulo-lingual (maior extensão da curvatura da superfície vestibular à maior curvatura na superfície lingual) e mésiodistal (maior extensão da curvatura da superfície mesial à curvatura da superfície distal), bem como a gêngivo-oclusal (ponto mais saliente da cúspide vestibular à junção cemento-esmalte) foram medidas através da utilização de um paquímetro e anotadas (Anexo A). Baseado nas dimensões médias apresentadas no trabalho de GALAN JUNIOR ${ }^{43}$ (VL 7,8-9,6; MD 5,9-7,4; GO 6,6-8,8) foram selecionados ao todo 56 dentes. Os mesmos foram incluídos por suas raízes até o nível cervical, $2 \mathrm{~mm}$ aquém da junção cemento-esmalte (Figura 27) com resina plástica híbrida (poliestirênica-acrílica) polimerizada quimicamente, vertida em um anel de PVC de 3 $\mathrm{cm}$ de comprimento e 1 polegada de diâmetro. A composição química desta resina 
(resapol, peroxol, pó de resina acrílica) quando ativada a reação, que é exotérmica, libera pouco calor, evitando-se o superaquecimento dos corpos de prova, o que foi indicado por ARAÚJO; CHIODI NETTO ${ }^{5}$. Os dentes foram fixados no seu longo eixo, através da utilização de grampos que permaneceram apoiados na superfície superior dos anéis de PVC até que houvesse completa polimerização da resina.

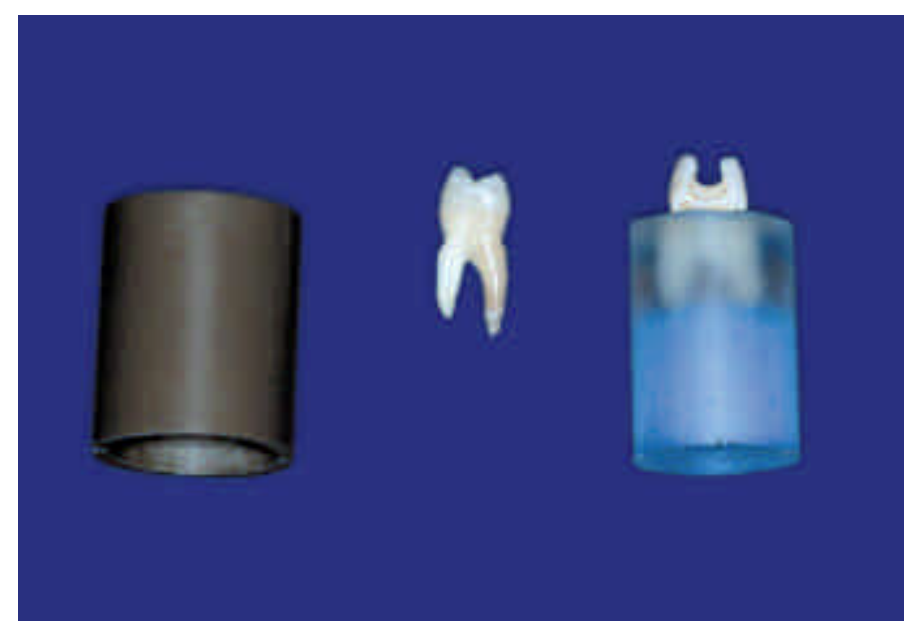

FIGURA 27 - Processo de inclusão dos dentes

Após a inclusão dos dentes, os mesmos foram divididos em sete grupos com oito dentes cada, sendo que um grupo foi o controle, de hígidos (Grupo 1), não recebendo qualquer tratamento. Os demais receberam preparos cavitários do tipo MOD. Assim, os dentes foram agrupados de acordo com o tipo de tratamento que receberam:

Grupo 2 - preparos cavitários do tipo MOD, realizados com broca carbide n.o 245 (S.S.White), acopladas a uma caneta de alta-rotação extra torque (Kavo Joinville, SC) sob refrigeração ar/água. A caixa oclusal foi confeccionada com uma profundidade de $2 \mathrm{~mm}$, possuindo forma arredondada e retentiva, sendo que o seu 
maior diâmetro de abertura oclusal correspondia à metade da distância intercuspídea. A caixa proximal foi realizada com a mesma broca, numa extensão de $2 \mathrm{~mm}$ abaixo da parede pulpar, e numa profundidade de $1,5 \mathrm{~mm}$, tendo a forma de gota ou sino, como preconizado por MONDELLI et al. ${ }^{75}$. Para cada preparo cavitário foi utilizada uma nova ponta carbide. A referência para a penetração inicial do instrumento rotatório de corte foi o sulco central dos dentes. Uma vez definido o posicionamento do mesmo, a alta rotação era acionada, sendo realizada à mão livre, um sulco de mesial à distal, até que se definisse a caixa oclusal. As dimensões dos preparos foram monitoradas através da utilização de uma lupa com $4 \mathrm{X}$ de aumento (Lactona), de um paquímetro e de uma sonda periodontal, que teve as suas extremidades padronizadas, sendo que em uma delas mensuraram-se 2,0 $\mathrm{mm}$ e na outra, 1,5 mm. A seguir, após a conclusão da caixa oclusal, confeccionaram-se as caixas proximais, iniciando-se sempre com movimentos pendulares de vestibular para lingual, sempre se verificando as medidas, até que se obtivessem as dimensões previamente estabelecidas e houvesse a união das caixas proximal e oclusal. Não se confeccionaram formas de retenção adicionais nos preparos cavitários. O acabamento da cavidade foi realizado com uma ponta diamantada n.o 715 (KG Sorensen), para peça de mão acoplada em um micro-motor de baixa rotação (Kavo), além da utilização de instrumentos manuais de Black (Duflex).

Assim, as cavidades tinham as seguintes características (Figuras 28, 29 e 30):

- caixa oclusal

- $\quad$ profundidade de 2,0 mm; 
- abertura de istmo de metade da distância entre os vértices das cúspides;

- paredes vestibular e lingual convergentes para oclusal;

- parede pulpar perpendicular ao eixo longitudinal;

- ângulos diedros e triedros arredondados;

- ângulo cavo superficial nítido e sem bisel.

- caixa proximal

- extensão de 2,0 mm da parede axial;

- profundidade de $1,5 \mathrm{~mm}$;

- a abertura da eqüivalia à metade do diâmetro vestíbulo-lingual em sua maior extensão;

- as paredes axiais tinham a característica de serem planas e com expulsividade para oclusal;

- as paredes vestibular e lingual convergentes para oclusal e ligeiramente divergentes no sentido áxio-proximal;

- parede gengival côncava vestíbulo lingualmente e ligeiramente expulsiva no sentido gêngivo-oclusal;

- ângulos internos arredondados, inclusive o áxio-pulpar; contorno externo em forma de gota d'água.

Este grupo não recebeu material restaurador. 


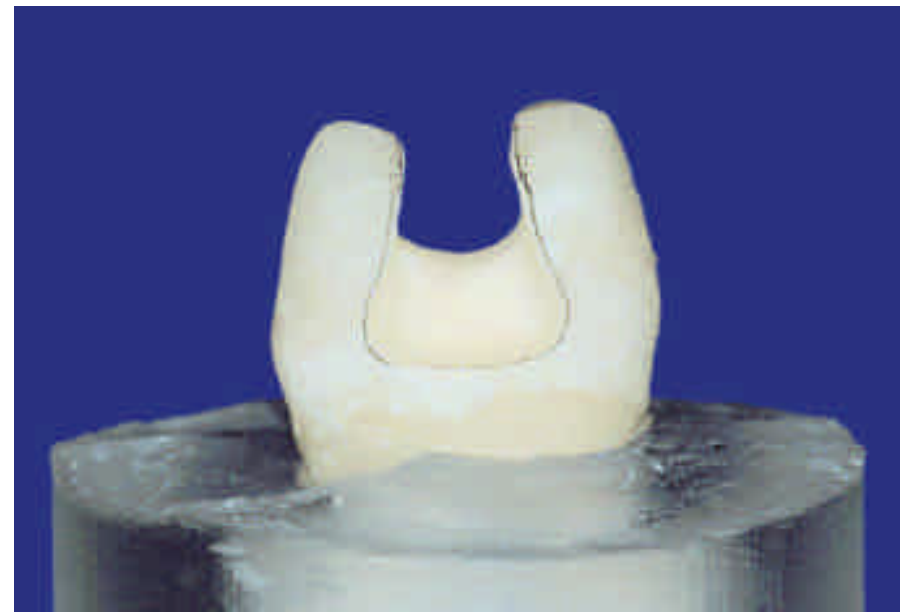

FIGURA 28 - Preparo cavitário para restaurações diretas

Vista proximal

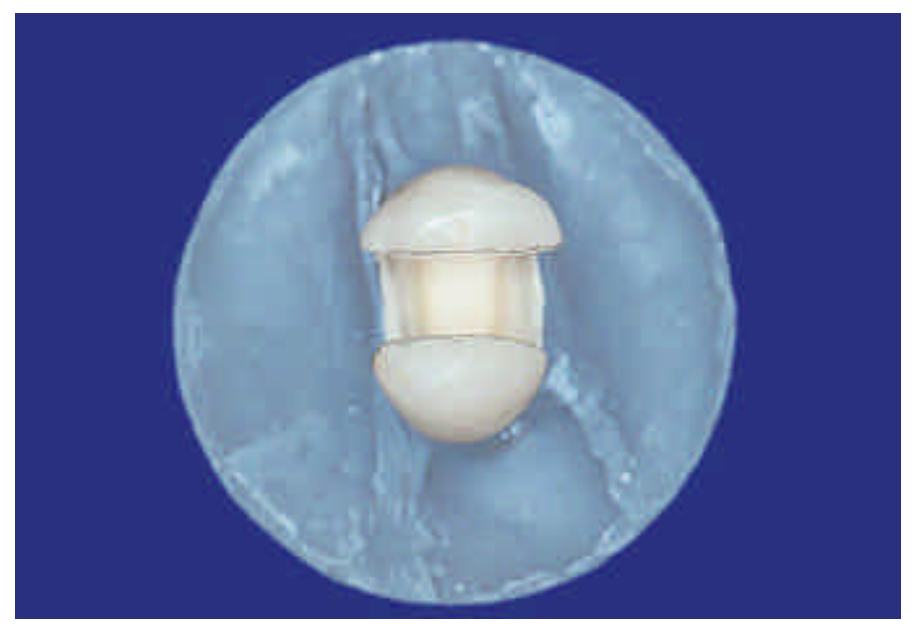

FIGURA 29 - Preparo cavitário para restaurações diretas Vista oclusal 


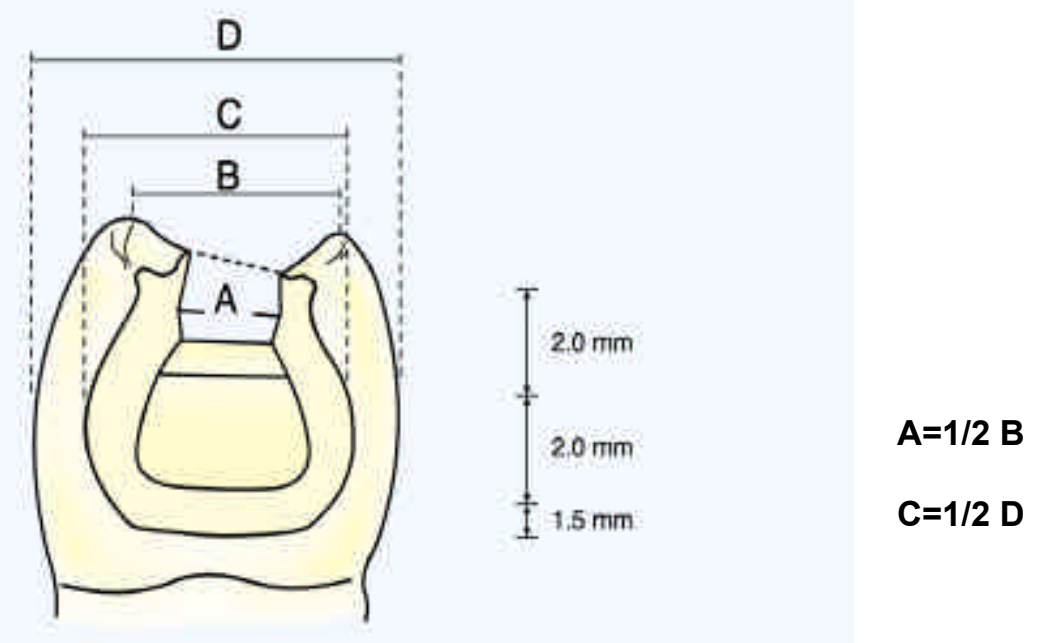

FIGURA 30 - Desenho esquemático do preparo para restaurações diretas

Grupo 3 - preparos cavitários tipo MOD, realizados com broca carbide n.o 2136 (KG Sorensen) em alta rotação sob refrigeração ar/água, baseado na configuração preconizada por MONDELLI et al. ${ }^{75}$. Para cada preparo cavitário foi utilizada uma nova ponta diamantada. A referência para a penetração inicial do instrumento rotatório de corte foi o sulco central dos dentes. Da mesma forma que no grupo anterior, uma vez definido o posicionamento do mesmo, a alta rotação era acionada, sendo realizada à mão livre, um sulco de mesial à distal, até que se definisse a caixa oclusal. As dimensões dos preparos também foram monitoradas através da utilização de uma lupa com $4 \mathrm{X}$ de aumento (Lactona), de um paquímetro e de uma sonda periodontal modificada. A seguir, após a conclusão da caixa oclusal, confeccionaram-se as caixas proximais, iniciando-se sempre com movimentos de vestibular para lingual, sempre se verificando as medidas, até que se obtivesse as dimensões previamente estabelecidas e houvesse a união das caixas proximal e oclusal. Não se confeccionaram formas de retenção adicionais nos preparos 
cavitários. O acabamento final dos preparos foi realizado com a ponta diamantada n.o 715 girando em velocidade convencional montada em peça de mão, acoplada a um micro-motor, além da utilização de instrumentos manuais de Black (Duflex). Assim, os preparos cavitários continham as seguintes características (Figuras 31, 32 e 33):

- caixa oclusal

- $\quad$ profundidade de $2 \mathrm{~mm}$;

- parede pulpar plana e perpendicular ao eixo longitudinal;

- paredes vestibular e lingual divergentes para oclusal;

- abertura de istmo de metade da distância intercuspídea.

- caixas proximais

- $\quad$ parede gengival foi realizado a $2 \mathrm{~mm}$ de extensão em relação à parede pulpar e com uma profundidade de $1,5 \mathrm{~mm}$;

- a abertura da caixa proximal correspondeu à metade do diâmetro vestíbulo-lingual,

- paredes divergentes para a oclusal;

- parede gengival plana no sentido gêngivo-oclusal e no sentido áxioproximal;

- $\quad$ ângulo áxio-pulpar e todos os ângulos internos foram arredondados;

- os ângulos gêngivo-lingual e gêngivo-vestibular foram também arredondados;

- o ângulo cavo superficial não foi biselado.

Este grupo não recebeu qualquer tratamento restaurador. 


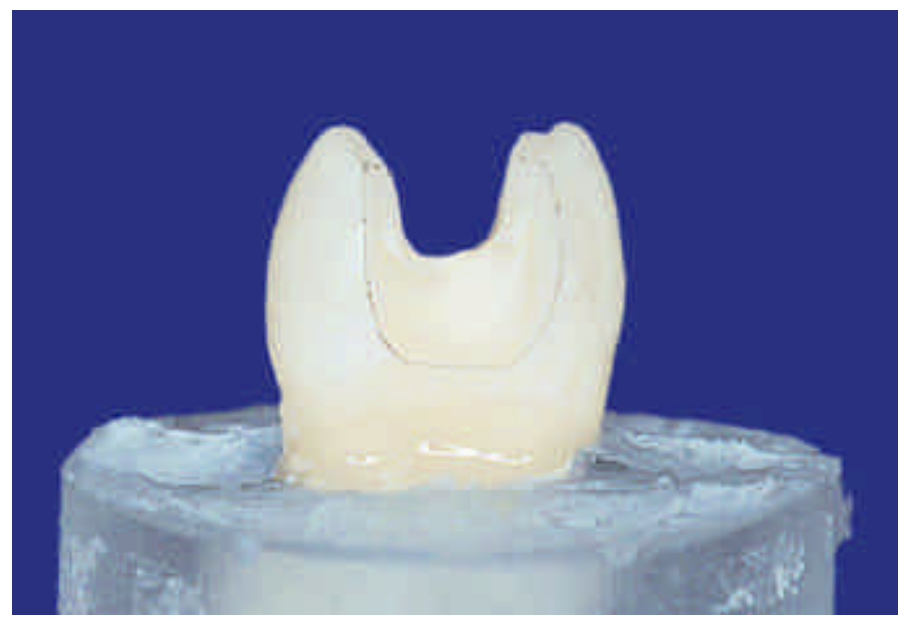

FIGURA 31 - Preparo cavitário para restaurações indiretas Vista proximal

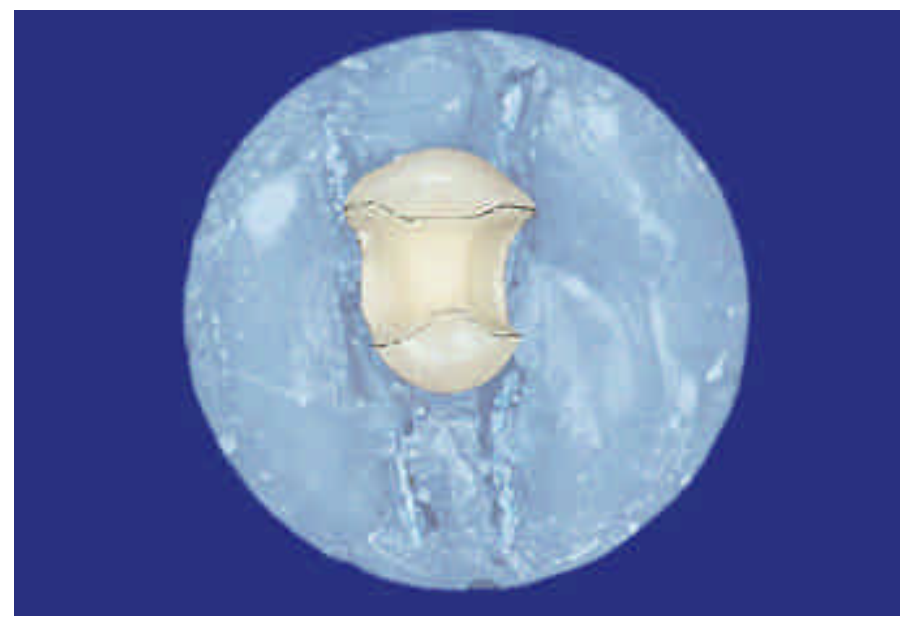

FIGURA 32 - Preparo cavitário para restaurações diretas Vista oclusal 


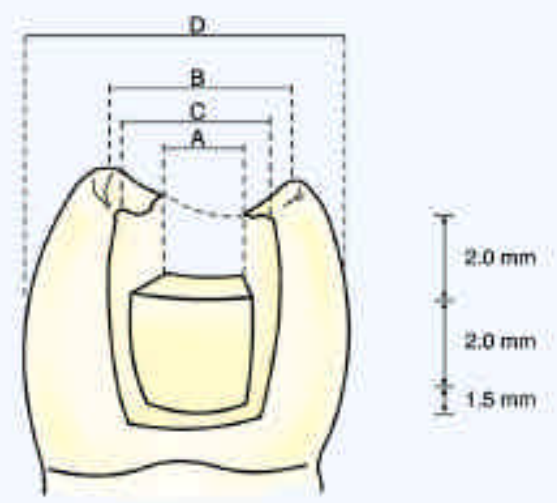

$A=1 / 2 \quad B$

$C=1 / 2 D$

FIGURA 33 - Desenho esquemático do preparo para restaurações indiretas

Grupo 4 - recebeu os mesmos preparos cavitários realizados no grupo 2, sendo restaurados com resina composta 3M Filtek Z250 na forma direta. Inicialmente lavaram-se as cavidades com Tergensol e secaram-se as mesmas com jatos de ar comprimido. Todas as paredes do preparo foram submetidas ao condicionamento com ácido fosfórico a $35 \%$ na forma de gel, por 15 segundos (3M Etching Gel 35\% weight phosphoric acid), e, a seguir, lavaram-se com jatos de água por 30 segundos e secaram-se com papel absorvente. $\mathrm{O}$ sistema adesivo foi então utilizado (3M Single Bond), sendo aplicadas duas camadas em todas as paredes do preparo, em esmalte e dentina, procedendo-se então a um leve jato de ar por 5 segundos, para que se evaporasse o solvente, e se realizasse então a fotopolimerização do mesmo por 10 segundos em cada face dos dentes. Aplicaramse incrementos de resina composta, com uma espátula metálica Hu Friedy mini 3, intercalados por fotopolimerização por 40 segundos. A inserção foi iniciada a partir das caixas proximais, seguindo a técnica incremental descrita por WIECZKOWSKI 
JUNIOR et al. ${ }^{117}$, onde a resina foi aplicada diagonalmente, de forma que se evitasse que as superfícies vestibular e lingual fossem ligadas por um incremento. Aplicaram-se dois incrementos diagonais nas caixas proximais até a altura do ângulo áxio-pulpar. As demais camadas foram aplicadas de forma semelhante que a descrita por este autor, com a diferença da aplicação de mais duas camadas na caixa oclusal, uma até a junção amelo-dentinária na parede lingual e outra até a mesma junção na parede vestibular, antes que se prosseguisse com a inserção das camadas para a conformação final da restauração (Figura 34). O aparelho de luz fotopolimerizadora utilizado foi o $3 M X L 3000$ possui uma ponteira de $7 \mathrm{~mm}$ com ângulo de $60^{\circ}$, e uma potência de $540 \mathrm{~mW} / \mathrm{cm}^{2}$. A luz foi posicionada o mais próximo possível do incremento aplicado, sem tocá-lo, por vestibular e por lingual, dependendo da posição da camada aplicada, até que o tempo de polimerização fosse terminado. Após o término da restauração, complementou-se a polimerização pela aplicação de luz por mais 40 segundos por mesial, distal e oclusal. Ao todo foram aplicados oito incrementos por dente. Limitou-se a aplicação do material restaurador até o ângulo cavo-superficial e realizou-se um esboço de uma escultura anatômica oclusal, procedendo-se à remoção dos excessos com lâmina de bisturi $n^{\circ}$ 15 e com brocas carbide multilaminada n.o 7802F (KG Sorensen). 


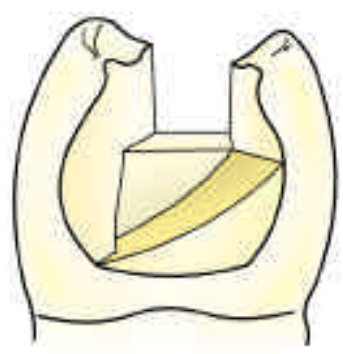

A

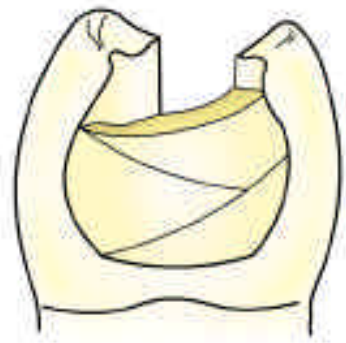

C

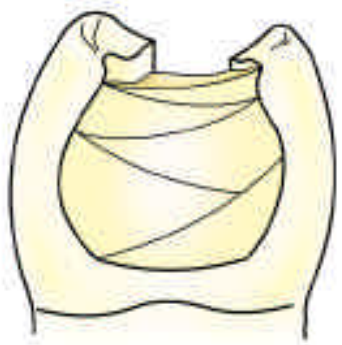

E

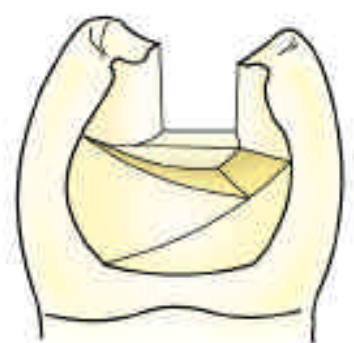

B

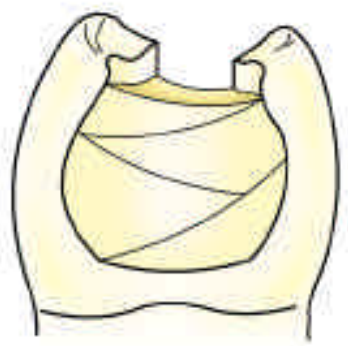

D

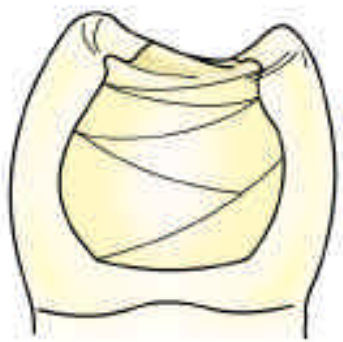

F

FIGURA 34 - Desenho esquemático da técnica de inserção da resina direta 
Grupo 5 - receberam os mesmos preparos cavitários realizados no grupo 3 e foram restaurados com restaurações indiretas de resina composta Artglass Heraeus-Kulzer. Foram realizados procedimentos de moldagem dos espécimes com poliéter (Impregum F - ESPE Dental, Medizin Germany), através da utilização de cilindros de PVC que tiveram uma extremidade selada com cera. A este dispositivo foi colocado o material de impressão, após a espatulação, através da utilização de uma seringa, sendo então introduzidos os corpos de prova para que se realizasse a moldagem. Após 3 minutos, foram removidos os espécimes dos dispositivos de PVC, onde foi realizado então o vazamento de gesso especial (Durone - Dentsply Co., Brasil), para que se confeccionassem os troquéis onde seriam confeccionadas as incrustações. Os troquéis foram identificados através de lápis-cópia, com a mesma numeração disposta nos dentes. Todos os troquéis receberam demarcação em seu limite periférico com lápis vermelho e os mesmos foram checados de forma que qualquer imperfeição como bolhas, rachaduras ou qualquer outra anormalidade que comprometesse o resultado final das incrustações, fazia com que todo 0 processo de moldagem e obtenção dos troquéis fosse repetido. Os troquéis deste grupo foram enviados para um laboratório de prótese particular ${ }^{\#}$ para que se confeccionassem as restaurações, sendo realizado por um mesmo técnico de forma a padronizá-las. Checou-se a adaptação das mesmas aos preparos através do auxílio de uma sonda clínica e da aplicação na superfície interna de um corante de carbono líquido azul, solúvel em água, da marca comercial Super Filme (Kota), que evidenciou as regiões que prejudicavam 0 assentamento das incrustrações.

\footnotetext{
\# Laboratório de Prótese Odair Caldeira - Jaú S.P.
} 
Estas regiões geralmente estavam limitadas às margens e que correspondiam ao excesso do material. Quando se observava que o evidenciador era removido em alguma região da superfície interna, fazia-se um desgaste cuidadoso com brocas diamantadas tronco cônica em peça de mão, acoplada a um micro-motor. Observada a correta adaptação das restaurações aos respectivos dentes, as mesmas eram lavadas com água para que o corante fosse eliminado. Após isso, as mesmas foram cimentadas nos respectivos dentes seguindo o protocolo dos fabricantes. O cimento resinoso utilizado foi o de dupla polimerização (foto e presa dual) da marca comercial $3 M$ Rely $X$ ARC Cimento Resinoso Adesivo, além do sistema adesivo que o conjunto contém (3M Single Bond). Os dentes foram lavados com Tergensol para que se promovesse limpeza e se removesse o corante e algum material gorduroso que porventura estivesse aderido à superfície do preparo ou do dente, para então se proceder à secagem. Realizou-se então o condicionamento ácido em todas as paredes com ácido fosfórico 35\% (3M Etching Gel 35\% weight phosphoric acid), por 15 segundos, sendo os dentes, então, lavados por 30 segundos e secos com papel absorvente. Aplicaram-se duas camadas do sistema adesivo e um leve jato de ar por 5 segundos, para que se evaporasse o solvente, fotopolimerizando-se em seguida por 10 segundos cada face do dente. As restaurações de resina composta indireta foram fixadas a um dispositivo denominado Kotafix (Kota), que é uma haste com uma cera pegajosa na extremidade, que se adere à superfície oclusal da incrustação, facilitando os procedimentos de cimentação. Todas as restaurações receberam um microabrasionamento com óxido de alumínio (Microetcher - Danville Engineering Inc.) com $50 \mu \mathrm{m}$ de espessura por 5 segundos, somente na superfície interna, lavando-se 
com spray água-ar. Aplicou-se, em seguida, ácido fosfórico a 35\% durante 30 segundos, seguido de uma lavagem abundante com água para que se removesse todo o ácido e partículas remanescentes de óxido. Ambos procedimentos foram realizados com o intuito de se criar microporosidades, aumentando-se a superfície a ser aderida e remover sujidades das mesmas. Pincelou-se na superfície interna, em seguida, o Ceramic Primer 3M (silano) por 30 segundos, sendo então aplicado um leve jato de ar durante 5 segundos. A aplicação do silano se justifica também com o intuito de melhorar a retenção, pois como descrito por alguns autores ${ }^{84,104,106}$, há uma maior efetividade na retenção de restaurações indiretas de resina composta quando se associam o micro-abrasionamento e o silano ao sistema adesivo. Proporcionou-se o cimento com a utilização do Clicker Dispenser do $3 M \operatorname{Rely~} X$ $A R C$, liberando as pastas base e catalisador em idêntica quantidades em uma placa de manipulação. Misturaram-se as pastas por 10 segundos com uma espátula de plástico e, através da mesma, se aplicou o cimento nas paredes internas das restaurações e no interior do preparo; e levaram-se em posição com a aplicação de uma leve compressão com o auxílio do Kotafix. Os corpos de prova foram colocados num aparato com um peso de 500 gramas, padronizando-se a pressão de cimentação (Figura 35). Após 3 a 5 minutos, removeram-se os excessos de cimento com lâmina de bisturi $n^{\circ} 15$. Fotopolimerizou-se por vestibular, por lingual, mesial, distal e, finalmente, por oclusal por um tempo de 40 segundos. $O$ aparelho de luz fotopolimerizadora utilizado foi o $3 M X L 3000$, o mesmo utilizado para o grupo anterior e para os demais. 


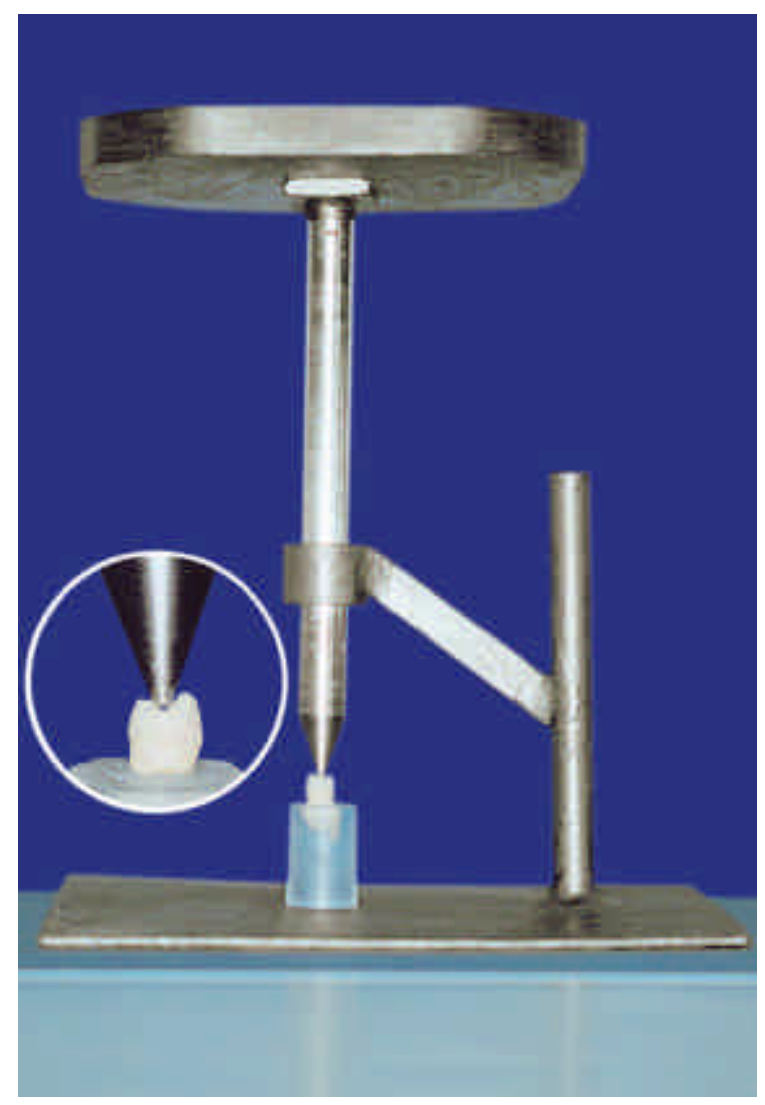

FIGURA 35 - Aparato utilizado para padronização da pressão de cimentação

Grupo 6 - realizaram-se preparos cavitários idênticos aos realizados no grupo 3 e procedeu-se da mesma forma que no grupo 5, com a diferença de que o material utilizado para restaurar os dentes foi uma resina composta indireta da marca comercial Targis (Ivoclar) $)^{\S}$

Grupo 7 - realizaram-se preparos cavitários idênticos aos realizados no grupo 3 e procedeu-se da mesma forma que no grupo 5, com a diferença de que o material utilizado para restaurar os dentes foi um material cerâmico da marca comercial IPS Empress (Ivoclar) ${ }^{\S}$. Outro procedimento que foi realizado

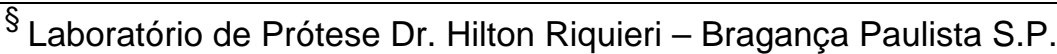


diferentemente do grupo 5, está relacionado ao tratamento que a superfície interna das restaurações recebeu. Após o jateamento com óxido de alumínio, foi aplicado ácido fluorídrico a 10\% (Dentsply) durante um minuto, após o qual foram lavadas abundantemente com spray de água-ar, para então se aplicar o Ceramic Primer $3 M^{* *}$ (silano).

TABELA 1 - Resumo dos sete grupos experimentais

Grupo 1 Controle, permaneceram sem qualquer tratamento

Grupo 2 Dentes com preparos cavitários classe II M.O.D., com paredes convergentes, não restaurados

Grupo 3 Dentes com preparos cavitários classe II M.O.D., com paredes divergentes, não restaurados

\section{Grupo 4 Preparos idênticos ao grupo} 2, restaurados com resina composta direta(Single Bond 3M/ Filtek Z 250 3M)

Grupo 5 Preparos idênticos ao grupo 3 , restaurados com resina composta indireta(Single Bond 3M/ Rely X 3M/ Artglass - Kulzer)

Grupo 6 Preparos idênticos ao grupo 3 , restaurados com resina composta indireta (Single Bond 3M/ Rely X3M/ Targis - Ivoclar)

Grupo 7 Preparos idênticos ao grupo 3, restaurados com porcelana (Single Bond 3M/ Rely X 3M/ IPS Empress Ivoclar) 
O perfil técnico dos materiais restauradores estão resumidos no Anexo B. Realizados os preparos cavitários e os procedimentos restauradores, os espécimes foram imersos em água deionizada por 7 dias, à temperatura ambiente. Após este período, procedeu-se aos ensaios de carregamento axial de compressão, que foi realizado em uma máquina de ensaios Universal (Kratus), com célula de carga de $2.000 \mathrm{~kg}$, regulada a uma carga máxima de 400 kgf, com uma leitura mínima de 0,05 kgf de precisão. A aplicação da força de compressão foi feita utilizando-se um cilindro de aço de $8 \mathrm{~mm}$ de diâmetro, acoplado a uma haste medindo $13 \mathrm{~cm}$ de comprimento, a uma velocidade de $0,5 \mathrm{~mm} / \mathrm{min}$. O diâmetro do cilindro foi utilizado levando-se em conta o diâmetro médio da base de cúspide de um pré-molar superior de forma a obter dois contatos nas vertentes cuspídeas vestibular e lingual dos dentes utilizados. Assim, a força de compressão foi transmitida somente ao dente, pois, o objetivo do trabalho foi verificar a resistência do dente e não dos materiais restauradores (Figura 36).

A utilização do cilindro de aço foi feita no intuito de se obter uma maior estabilidade nos testes de compressão, visto que, como mencionado na literatura ${ }^{21}$, e de acordo com o projeto piloto realizado previamente aos testes definitivos, quando da utilização de uma esfera de aço, há uma tendência ao escorregamento, mesmo quando se realizaram nichos em esmalte, o que ficaria prejudicada a confiabilidade dos resultados. O uso de uma esfera poderia simular um contato cúspide-fossa, mas como o objetivo era a verificação da resistência à fratura dos dentes, e a superfície de contato fosse praticamente a mesma, optou-se pela utilização do cilindro de aço (Figura 37), embora os testes realizados por meio do mesmo, fazem com que o padrão de fratura seja mais severo. 


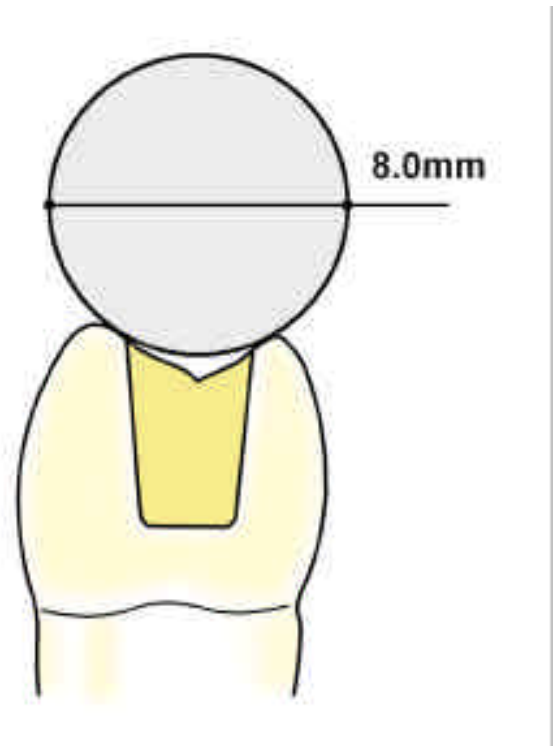

FIGURA 36 - Desenho esquemático do teste de compressão

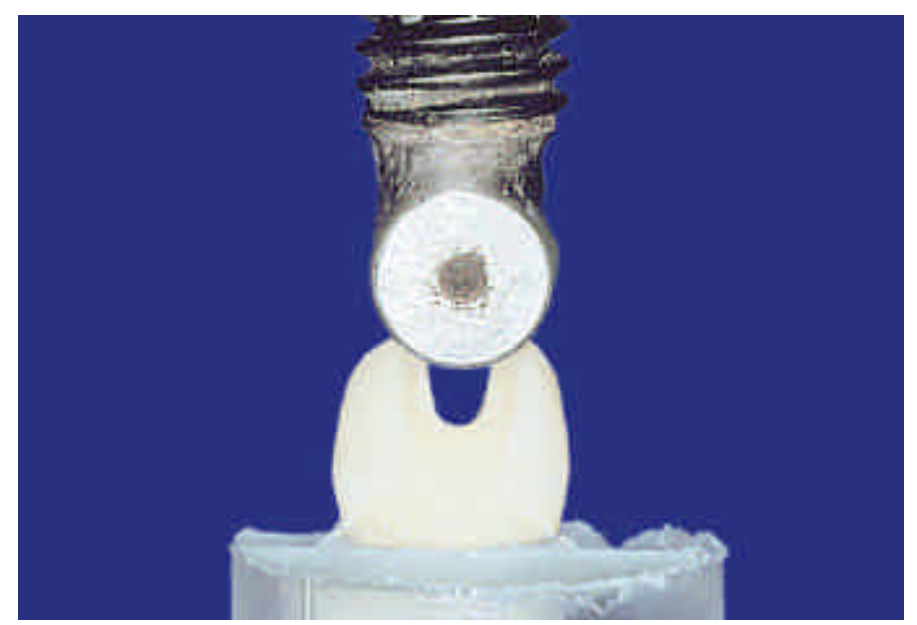

FIGURA 37 - Teste de compressão axial 
O teste de compressão axial foi realizado nos corpos de prova, que foram posicionados na base metálica da máquina de ensaios. Nichos foram realizados nas vertentes triturantes das cúspides para promover uma melhor adaptação do cilindro, evitando seu deslizamento, e melhor direcionamento da força. Através da verificação, com o auxílio de uma lupa, de que havia o contato em ambas as cúspides, sem que houvesse carga, a máquina era acionada. $O$ teste transcorria com a aplicação de carga até que houvesse fratura do corpo de prova, o que fazia com que a máquina parasse e acusasse através de um sinal sonoro que o mesmo havia terminado. Um computador que contém um programa específico, acoplado à máquina de ensaios, registrava os valores, e ainda mostrava a curva de evolução da aplicação da força até que houvesse a fratura. Após a realização dos testes, os dados foram coletados e procedeu-se à análise estatística.

Para que se analisasse a forma como os espécimes se fraturaram nos grupos que receberam material restaurador, após a realização dos testes de resistência, registrou-se o padrão de fratura nestes dentes, seguindo critérios baseados no trabalho realizado por BURKE et al. ${ }^{21}$ (Figura 24).

O padrão de fratura seguiu então a seguinte classificação:

Modo I - mínima destruição do dente

Modo II - fratura de uma das cúspides, sem envolver restauração

Modo III - fratura de um das cúspides, com envolvimento de até $1 / 2$ da restauração

Modo IV - fratura de uma das cúspides com envolvimento de mais da $1 / 2$ da restauração 
Modo V - fratura severa com envolvimento completo do dente ou com fratura longitudinal. 
RESULTADOS 


\section{5 - RESULTADOS}

Após a realização dos procedimentos experimentais, como descritos na metodologia, os dados foram anotados e analisados estatisticamente. A média dos valores obtidos, além dos dados da estatística básica descritiva, são apresentados na tabela a seguir. Os valores individuais da resistência à fratura bem como as dimensões dos corpos de prova, estão registrados no Anexo A.

TABELA 2 - Análise descritiva da estatística básica (Valores em kgf)

\begin{tabular}{crrrrrr} 
GRUPOS & MÉDIAS & \multicolumn{1}{c}{$\boldsymbol{D} \boldsymbol{P}$} & MEDIANA & MÁXIMO & MÍNIMO & AMOSTRA \\
$\mathbf{1}$ & 193,93 & 24,46 & 187,00 & 238,25 & 164,75 & 8 \\
$\mathbf{2}$ & 108,56 & 21,39 & 112,51 & 130,50 & 60,25 & 8 \\
$\mathbf{3}$ & 95,43 & 17,73 & 98,50 & 114,75 & 70,00 & 8 \\
$\mathbf{4}$ & 147,65 & 32,63 & 153,62 & 185,00 & 104,75 & 8 \\
$\mathbf{5}$ & 184,15 & 56,49 & 172,12 & 277,00 & 127,25 & 8 \\
$\mathbf{6}$ & 183,81 & 31,95 & 182,62 & 231,50 & 143,75 & 8 \\
$\mathbf{7}$ & 181,12 & 40,49 & 178,00 & 238,50 & 136,50 & 8
\end{tabular}

Grupo 1 - Hígidos

Grupo 2 -Preparo Classe II MOD, convergentes, Sem Restauração

Grupo 3 -Preparo Classe II MOD, divergentes, Sem Restauração

Grupo 4 - Mesmo preparo que o grupo 2, resina direta Filtek Z 250 3M

Grupo 5-Mesmo preparo que o grupo 3, resina indireta Artglass Kulzer

Grupo 6 - Mesmo preparo que o grupo 3, resina indireta Targis Ivoclar

Grupo 7 - Mesmo preparo que o grupo 3, porcelana IPS Empress 
A Figura a seguir demonstra graficamente os valores de resistência à fratura e seus respectivos valores de desvio padrão, frente aos ensaios de compressão realizados.

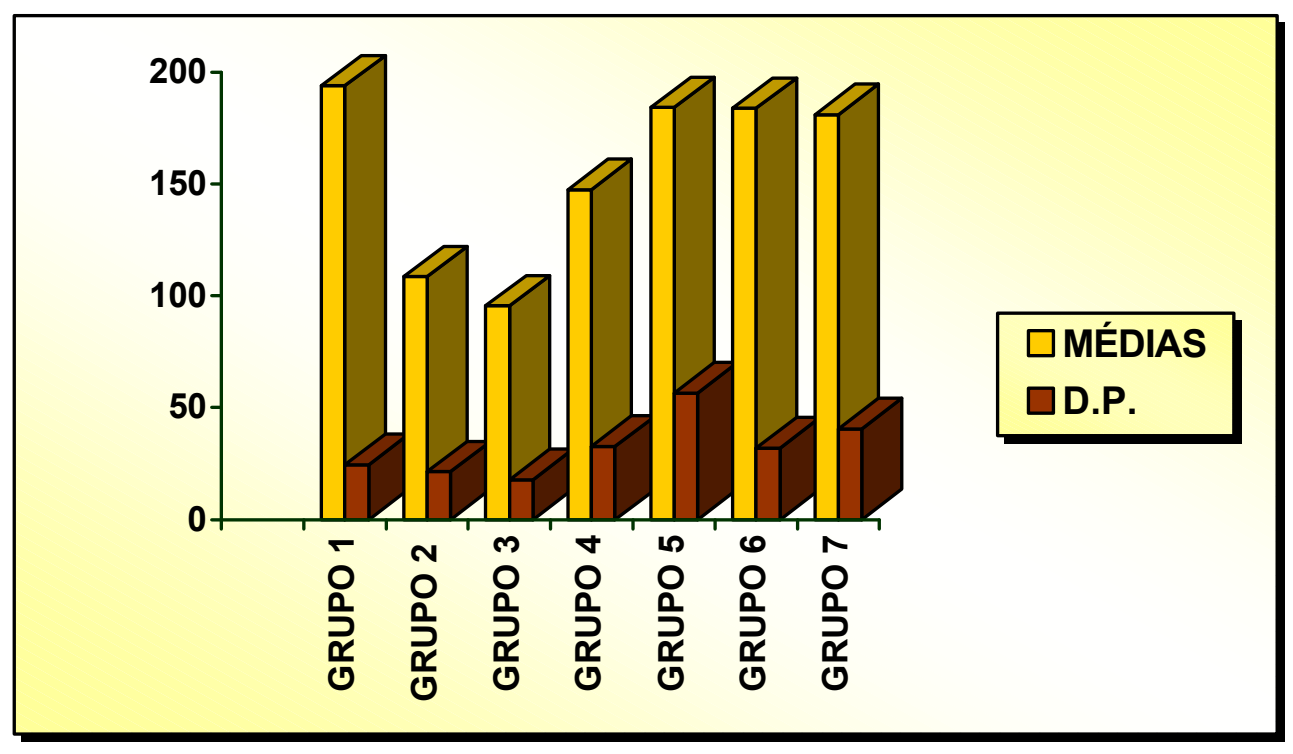

FIGURA 38 - Gráfico representativo das médias dos valores obtidos

Através da análise do gráfico acima, pode-se observar que as médias apresentadas pelos grupos que receberam restaurações indiretas foram bem próximas às do controle de hígidos, que apresentou os maiores valores. Os grupos 5, 6 e 7 apresentaram os maiores desvios padrão, sendo que os mesmos continham um maior número de variáveis envolvidas. Os grupos que receberam somente preparos cavitários (controle negativo) apresentaram as menores médias, sendo que o grupo 2 apresentou valores maiores que o grupo 3. A média dos valores do grupo 4 foi maior que a do grupo 2, mas inferior aos apresentados pelos grupos que receberam restaurações indiretas. 
A Figura 39 mostra um histograma em que estão contidas as distribuições dos valores encontrados na Tabela 2.
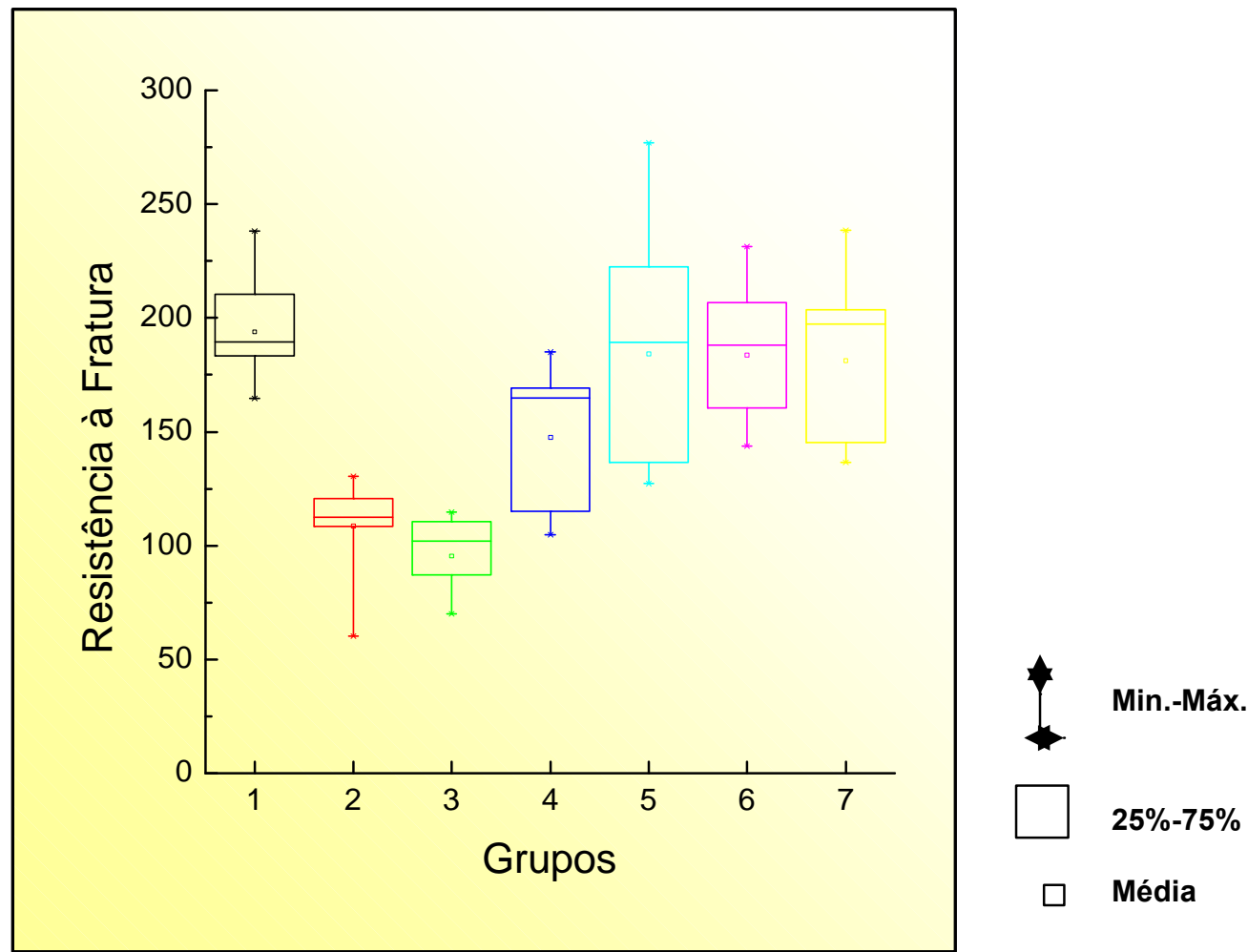

FIGURA 39 - Histograma do tipo Box-and-Whisker Plot

Este diagrama demonstra a metade principal da distribuição dos valores interquartis $\left(1^{\circ}, 25 \%\right.$ e $\left.3^{\circ}, 75 \%\right)$, onde se encontram os dados mais estáveis. Verifica-se que os grupos experimentais 2 e 3, apresentaram um comportamento próximo entre si, mas inferior ao grupo-controle e aos demais grupos estudados. Os grupos que receberam restaurações indiretas mostraram distribuição de valores semelhantes, sendo que o grupo 6 mostrou valores mais homogêneos e mais próximos aos grupo controle (grupo 1). O grupo 4 mostrou comportamento inferior aos apresentados pelos demais grupos que receberam material restaurador. 
A análise estatística consistiu na realização de análise de variância (ANOVA) a um critério, a um nível de significância de 5\%, para se verificar estatisticamente, o comparativo dos grupos experimentais entre si, e entre eles e os grupos controle. Para se analisar e comparar os grupos aos pares, foi realizado o teste de Tukey.

A tabela a seguir mostra os valores da análise de variância, a um critério, onde se apontou o estimador de variância "F", que indicou que havia diferença estatística entre as médias de resistência dos grupos.

TABELA 3 - Resultado do teste de análise de variância Um critério de classificação - Modelo Fixo

\begin{tabular}{llcccc}
$\begin{array}{l}\text { Fonte de } \\
\text { Variação }\end{array}$ & $\begin{array}{l}\text { Soma de } \\
\text { Quadrados }\end{array}$ & $\begin{array}{c}\text { Graus de } \\
\text { Liberdade }\end{array}$ & $\begin{array}{c}\text { Quadrado } \\
\text { médio }\end{array}$ & “F” & Probab. \\
\hline Entre grupos & 76966.6786 & 6 & 12827.7798 & 10.8266 & .00000012 \\
Resíduo & 58057.3203 & 49 & 1184.8433 & & \\
\hline Total & $\mathbf{1 3 5 0 2 3 . 9 9 9}$ & $\mathbf{5 5}$ & & & \\
& & & & & \\
\hline
\end{tabular}

A análise de variância a um critério (Tabela 2) aplicada aos valores de resistência, identificou uma diferença estatisticamente significante entre as condições estudadas. No intuito de se detectar qual das condições foi responsável pela significância estatística, foi aplicado o teste de Tukey para as comparações individuais. 
$\mathrm{Na}$ Tabela a seguir está demonstrado o teste de comparações múltiplas, onde se fizeram comparações individuais aos pares para se interpretar estatisticamente se houve diferença significante entre os mesmos.

TABELA 4 - Comparações Individuais - Teste de Tukey ${ }^{\S}$

\begin{tabular}{|lrrl|}
\hline \hline Comparação & Diferença & Valor crítico & Interpretação \\
\hline \hline $\mathbf{1 X 2}$ & 85.375 & 52.925 & Significante \\
$\mathbf{1 X 3}$ & 98.468 & 52.925 & Significante \\
$\mathbf{1 X 4}$ & 46.343 & 52.925 & Não Signif. \\
$\mathbf{1 X 5}$ & 9.781 & 52.925 & Não Signif. \\
$\mathbf{1 X 6}$ & 10.125 & 52.925 & Não Signif. \\
$\mathbf{1 X 7}$ & 12.812 & 52.925 & Não Signif. \\
$\mathbf{2 X 3}$ & 13.093 & 52.925 & Não Signif. \\
$\mathbf{2 X 4}$ & -39.031 & 52.925 & Não Signif. \\
$\mathbf{3 X 5}$ & -88.687 & 52.925 & Significante \\
$\mathbf{3 X 6}$ & -88.343 & 52.925 & Significante \\
$\mathbf{3 X 7}$ & -85.656 & 52.925 & Significante \\
$\mathbf{4 X 5}$ & -36.562 & 52.925 & Não Signif. \\
$\mathbf{4 X 6}$ & -36.218 & 52.925 & Não Signif. \\
$\mathbf{4 X 7}$ & -33.531 & 52.925 & Não Signif. \\
$\mathbf{5 X 6}$ & 0.343 & 52.925 & Não Signif. \\
$\mathbf{5 X 7}$ & 3.031 & 52.925 & Não Signif. \\
$\mathbf{6 X 7}$ & 2.687 & 52.925 & Não Signif. \\
\hline
\end{tabular}

$\S$ Nível de significância para o conjunto de testes: 5,0\% 
A Tabela que se segue demonstra o padrão de fratura que se observou individualmente nos corpos de prova dos grupos que receberam material restaurador.

TABELA 5 - Padrão de fratura apresentado pelos grupos restaurados

\begin{tabular}{|c|c|c|c|c|}
\hline & $\begin{array}{c}\text { Grupo } \\
4\end{array}$ & $\begin{array}{c}\text { Grupo } \\
5\end{array}$ & $\begin{array}{c}\text { Grupo } \\
6\end{array}$ & $\begin{array}{c}\text { Grupo } \\
7\end{array}$ \\
\hline 1 & II & II & III & V \\
\hline 2 & II & IV & III & III \\
\hline 3 & IV & II & III & IV \\
\hline 4 & I & III & IV & $\mathrm{V}^{* *}$ \\
\hline 5 & II & III & $\mathrm{V}^{*}$ & II \\
\hline 6 & II & IV & V & IV \\
\hline 7 & II & IV & III & IV \\
\hline 8 & II & $\mathrm{V}^{* *}$ & V & $\mathrm{V}^{*}$ \\
\hline
\end{tabular}

${ }^{*} D C$ - destruição completa

${ }^{* *} F L$ - fratura longitudinal

Nas Figuras a seguir estão demonstrados exemplares de padrão de fratura que ocorreram nos corpos de prova que receberam materiais restauradores. Podese observar claramente que os padrões exibidos pelos corpos de prova que receberam restaurações indiretas foram os mais severos, sendo que alguns deles apresentaram fratura longitudinal ou até a completa destruição do dente. 

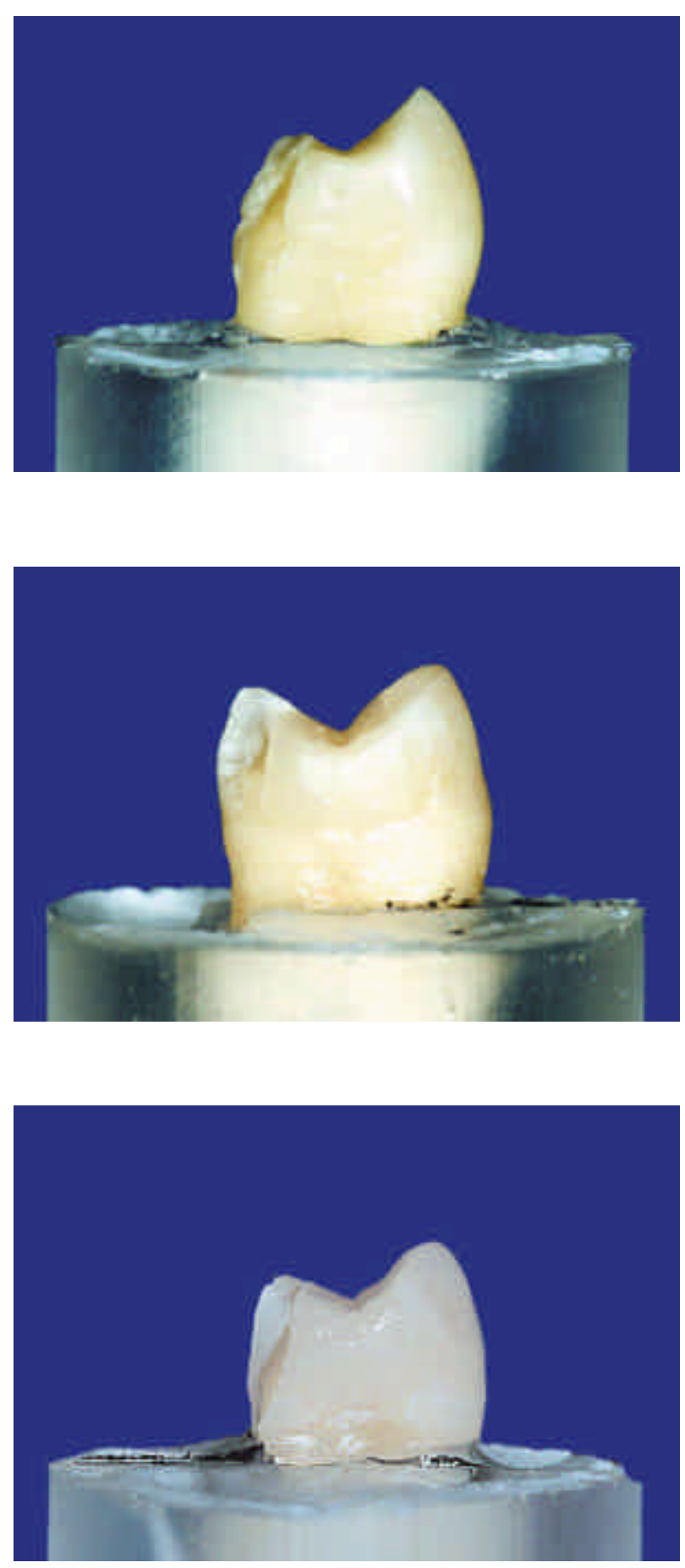

FIGURA 40 - Padrões de fratura apresentados pelos corpos de prova restaurados com restaurações diretas de Filtek Z250 

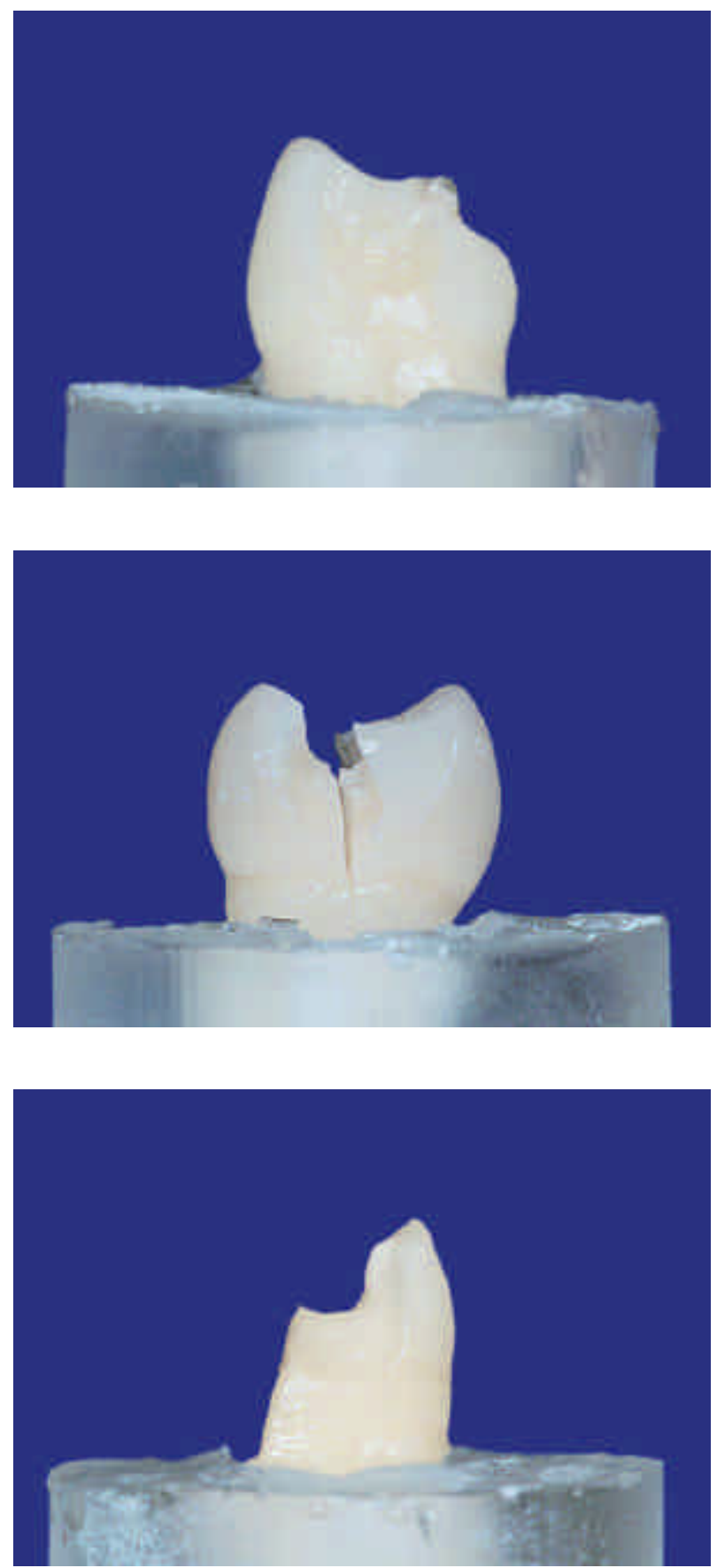

FIGURA 41 - Padrões de fratura apresentados pelos corpos de prova restaurados com restauração indireta de resina composta Artglass 

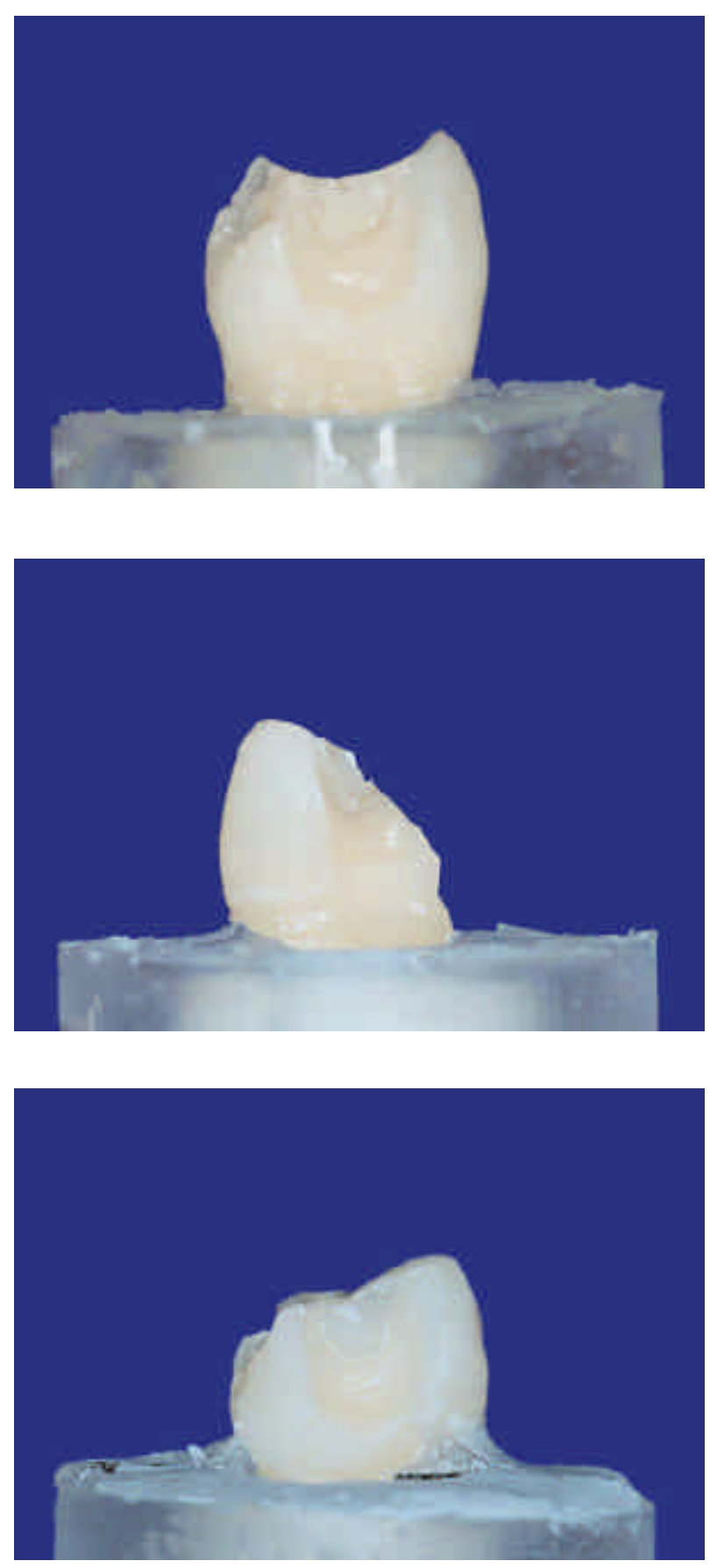

FIGURA 42 - Padrões de fratura apresentados pelos corpos de prova restaurados com restaurações indiretas de resina composta Targis 

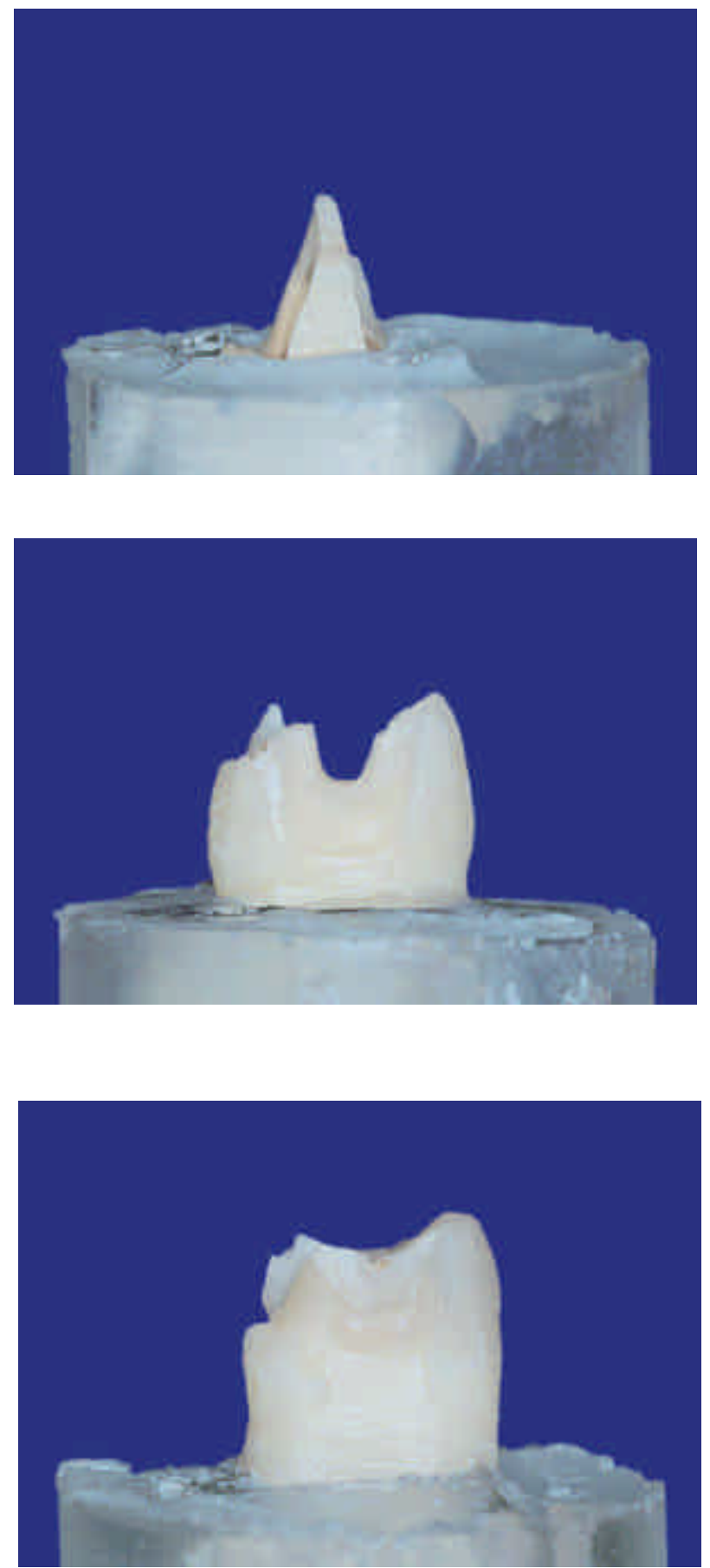

FIGURA 43 - Padrões de fratura apresentados pelos corpos de prova restaurados com restaurações indiretas de porcelana IPS Empress 
Como já mencionado anteriormente, o padrão de fratura apresentado quando da utilização do cilindro de aço é mais severo, apesar da confiabilidade dos resultados ser maior. Na eventualidade da ocorrência destes padrões mais severos, haveria menor possibilidade de recuperação do remanescente. Mesmo assim, os valores apresentados pelos grupos restaurados com restaurações indiretas foram próximos ao das médias de valores apresentados pelo grupo de hígidos, o que demonstra clinicamente uma menor possibilidade da ocorrência deste padrão de fratura, já que a resistência dos dentes foi quase que completamente restabelecida. $\mathrm{Na}$ maioria dos casos, ocorreu falha adesiva no grupo de dentes restaurados com restauração indireta. Em relação ao grupo de dentes restaurados com resina direta, a média dos valores foi menor e o padrão de fratura foi bem menos severo, o que significaria clinicamente que haveria maior possibilidade de recuperação do dente, caso houvesse fratura do remanescente. $O$ tipo de falha mais presente nestes casos foi da cúspide palatina, com a restauração permanecendo intacta na maioria dos casos, aderida ao dente. 
DISCUSSÃO 


\section{6 - DISCUSSÃO}

A ocorrência de fraturas nos dentes posteriores é freqüente, uma vez que estão sujeitos a uma série de injúrias como abrasão, erosão, cáries e procedimentos restauradores extensos, que levam ao enfraquecimento da estrutura dentária ${ }^{35}$. Esta fratura, que ocorre mais particularmente nas cúspides, varia em severidade desde o mínimo envolvimento de esmalte, até fraturas longitudinais, que levam invariavelmente à perda do dente. Destacam-se ainda outras causas como contatos prematuros das cúspides durante os movimentos mastigatórios, maloclusão, desgaste, desidratação devido à terapia endodôntica ${ }^{7}$ e devido ainda à própria morfologia e à anatomia das cúspides dos dentes ${ }^{13,26,35}$. Segundo alguns autores $^{23,26,35,102}$, a fratura dos dentes varia também com a idade dos pacientes, com o tipo de dente, com as dimensões dos preparos cavitários e ainda com o tipo de material restaurador utilizado. A circunstância em que ocorre pode ser ainda durante as funções mastigatórias ou através de um trauma ${ }^{93,103}$.

Ao se planejar a execução de um procedimento restaurador, a remoção do processo carioso e o conseqüente tratamento mecânico destas lesões, ocorre um enfraquecimento do dente, salientando-se a preocupação com a integridade do remanescente dentário e a vitalidade do complexo dentinopulpar ${ }^{75}$. A precoce intervenção nos processos cariosos, através de técnicas preventivas e a realização de preparos cavitários mais conservativos, deverão proporcionar uma maior longevidade da estrutura dentária, prevenindo a ocorrência de maiores danos à integridade dos dentes. Ao se deparar com um caso de fratura, a avaliação da 
estrutura remanescente e a correta execução dos procedimentos restauradores contribuem para o restabelecimento da função e da estética.

A avaliação da resistência à fratura, mais freqüentemente encontrada na literatura, é através de pesquisas laboratoriais, em que se realizam testes de compressão, utilizando-se de uma esfera ou cilindro de aço acoplados a uma máquina de ensaios, até que ocorra a fratura dos corpos de prova $^{8,9,11,14,15,20,37,46,57,58,59,62,63,66,74,76,81,88,95,97,113}$. Há na literatura alguns trabalhos importantes $^{67,77,97}$, em que se realizaram testes não destrutivos de carregamento axial, com o intuito de se avaliar a flexão das cúspides de dentes que receberam preparos cavitários e materiais restauradores. Nestes casos aplica-se uma força nas vertentes de cúspide, que vão ter medidores acoplados à superfície. Há ainda trabalhos em que se utilizou aplicação de forças de impacto, simulando situações de oclusão e trauma ${ }^{94}$. Na presente investigação foram utilizados testes destrutivos de compressão e, embora o resultado das avaliações in vitro não representem fielmente as situações clínicas, são os mais amplamente utilizados, podendo-se observar o comportamento dos dentes frente aos variados preparos cavitários realizados e materiais restauradores utilizados. Neste caso, a aplicação das forças ocorreu sobre as vertentes das cúspides vestibular e palatina através de um cilindro de aço, sem que tocasse as restaurações. Com isso, sob ação destas forças compressivas, há uma deformação das mesmas no sentido da separação das cúspides, sendo que a resultante das forças de tensão vai se localizar na interface dente-restauração ${ }^{13}$.

Os dentes pré-molares superiores são os mais utilizados em testes de resistência, devido ao fato de apresentarem uma tendência à deflexão das cúspides, quando sob esforços oclusais, além do envolvimento estético quando ocorre grande 
destruição por cárie ou fratura, indicando-se a realização de restaurações estéticas adesivas. A revisão da literatura mostrou ainda a utilização deste grupo de dentes em investigações clínicas, demonstrando-se in vivo uma ocorrência quatro vezes maior de fratura nos pré-molares superiores em relação aos inferiores ${ }^{73}$. Além disso, apresentam uma anatomia coronária mais uniforme em relação aos molares, sendo que, principalmente nos segundos pré-molares, as cúspides geralmente são da mesma altura.

A importância da realização de preparos cavitários modernos, mais conservativos em contrapartida aos extensivamente praticados anteriormente, tem sido defendido como a melhor forma de se preservar a resistência dos dentes. De fato, a influência da remoção dos tecidos nos diferentes tipos de preparo e a conseqüente restauração do remanescente têm sido investigados por diversos autores $^{15,18,32,37,63,74,81,96,98,114}$. Os preparos cavitários para restaurações diretas realizados neste estudo possuíam paredes convergentes para oclusal, possibilitando uma auto-retentividade no sentido gêngivo-oclusal, além de proporcionar um volume adequado de material restaurador na caixa oclusal ${ }^{75}$. Os ângulos internos foram arredondados para diminuir os pontos de concentração de esforços, bem como facilitar o escoamento e adaptação do material durante a sua inserção. 0 arredondamento do ângulo áxio-pulpar faz com que haja uma diminuição da concentração de tensões neste ponto, diminuindo o risco de fratura da restauração. A forma da caixa proximal em forma de sino, cuja conformação corresponderia à remoção do processo carioso, preserva maior quantidade de estrutura dentária, e propicia um maior número de prismas cortados transversalmente, e por conseguinte, uma melhora no selamento marginal, retenção e resistência da restauração, além da 
economia de tecido dental ${ }^{27}$. Já os grupos que receberam preparos cavitários para restaurações indiretas tiveram as paredes circundantes divergentes para a oclusal, observando-se o plano de inserção e remoção da restauração, facilitando as etapas de ajuste e cimentação das mesmas. As dimensões dos preparos cavitários foram as mesmas dos preparos para restaurações diretas, tendo a caixa oclusal uma profundidade de $2,0 \mathrm{~mm}$ e a parede axial uma profundidade de $1,5 \mathrm{~mm}$ no intuito de propiciar uma espessura mínima adequada para a resistência do material restaurador. O cavo-superficial era nítido e sem bisel, possibilitando uma linha de cimentação mínima. Os ângulos internos também foram arredondados, evitando-se a concentração de esforços nestas áreas ${ }^{15,75}$.

A média dos valores apresentados pelos grupos 2 e 3 , que foram os grupos que receberam apenas preparos cavitários acima descritos, sem serem restaurados, foi respectivamente, $\mathbf{1 0 8 , 5 6}$ e $\mathbf{9 5 , 4 6}$ kgf Observou-se que os preparos cavitários reduziram significantemente a resistência dos dentes, quando se comparou ao grupo controle $(\mathbf{1 9 3 , 9 3} \mathbf{k g f})$, havendo concordância com os demais estudos ${ }^{37,81,88,95,96}$, em que afirmam haver uma redução na resistência à fratura, proporcional à remoção dos tecidos e em relação às dimensões dos preparos. Analisando-se estatisticamente as médias dos valores apresentados pelos grupos 2 e 3, verificouse que não houve diferença significante na resistência dos dentes quando se compararam os diferentes tipos de preparo cavitário. Apesar disso, o grupo 2 apresentou valores numéricos maiores que o grupo 3, observando-se que, como enfatizado na literatura ${ }^{9,74,81,96}$, houve uma maior remoção de tecido quando da realização dos preparos indiretos, conseqüentemente ocasionando uma maior perda da resistência da estrutura dentária. Segundo $S E N E^{96}$, os preparos indiretos 
removem cerca de $40 \%$ mais estrutura dentária que os preparos diretos. Além disso, provavelmente devido à configuração dos preparos cavitários para resina direta, há uma maior preservação das cúspides, ao contrário dos preparos realizados no grupo 3, que pela própria expulsividade das paredes, fez com que o cilindro atuasse com um maior efeito de cunha, havendo então forte tendência à separação das mesmas.

VALE ${ }^{109}$, em 1956, observou que, ao se aumentar a abertura da cavidade de 1/4 para 1/3 da distância intercuspídea, havia uma queda acentuada na resistência à fratura dos dentes. Nos trabalhos de MONDELLI et al. ${ }^{74}, 1980$, LARSON; DOUGLAS; GEISTFELD ${ }^{63}, 1981$, verifica-se também uma concordância de que a remoção de estruturas de reforço e a amplitude das cavidades são fatores decisivos na redução da resistência do remanescente dentário. NAVARRO et al. ${ }^{81}$ em 1983, encontraram valores de $70 \%$ de queda na resistência dos dentes que tiveram envolvimento das cristas marginais por processo carioso e uma redução de $90 \%$ quando se removeu o teto da câmara pulpar. Já, BLASER et al. ${ }^{9}$, em 1983, afirmaram que o fator mais diretamente relacionado com o enfraquecimento do remanescente correspondia à profundidade dos preparos, sendo a largura menos importante para que isso ocorresse. De forma geral, todos estes trabalhos, apesar das diferenças na metodologia, resultados e conclusões, são concordantes de que há uma progressiva diminuição na resistência à fratura dos dentes, à medida que se remove tecido dentário, quer em relação à profundidade ou à extensão, e da eliminação de estruturas de reforço importantes como cristas marginais e o teto da câmara pulpar dos dentes $8,9,37,46,57,58,59,62,63,66,74,76,81,88,95,97,109$. 
Os valores de resistência apresentados pelos grupos que receberam apenas preparos cavitários (grupos 2 e 3) corresponderam, respectivamente, a 56 e 49\% da média dos valores apresentados pelo grupo controle, observando-se que as médias obtidas neste estudo estão em concordância com a literatura consultada. A magnitude dos valores apresentados neste estudo em comparação aos demais é devido às diferenças na metodologia empregada, à anatomia dos dentes selecionados, à dimensão dos preparos cavitários realizados em cada um deles, além da área de contato que ocorreu entre o cilindro de aço e as vertentes de cúspide, mencionando-se ainda as diferenças quanto ao teste de compressão propriamente dito. Como descrito por BURKE et al. ${ }^{21}$ em 1993, a utilização de um cilindro ou barra de aço proporciona uma maior estabilidade, visto que a esfera de aço tende a "escorregar", apresentando valores que podem gerar dúvida. Desta forma, o cilindro vai ter uma área de contato maior nas vertentes; sendo assim, maior será a força necessária para fraturar os corpos de prova. Isto pode explicar ainda as variações que ocorrem em relação aos resultados apresentados dentro de um mesmo grupo, também encontradas na literatura, que podem ainda ser devido as diferenças anatômicas oclusais de cada dente selecionado, além das características morfológicas individuais ${ }^{46}$. Os resultados apresentados pelo grupo 1 (controle) foram os mais altos, visto que não receberam qualquer tratamento, sendo que esta média foi maior que a observada em alguns trabalhos ${ }^{37,74,76,81}$, que apresentaram valores médios em torno de $170 \mathrm{kgf}$, também devidos aos fatores previamente discutidos.

Como mencionado anteriormente, o material restaurador exerce fundamental importância no fortalecimento do remanescente dentário. Vários trabalhos na 
literatura demonstraram a eficácia das restaurações de resina composta como material de reforço dentário ${ }^{6,30,33,57,69,71,73}$, já que são capazes de aderir aos tecidos dentários, reduzindo a flexão das cúspides ${ }^{67,77,105}$, reduzindo assim a possibilidade da ocorrência de fratura das mesmas ${ }^{46,71,96}$. A resina composta de inserção direta utilizada neste estudo foi a marca comercial Filtek Z250 da 3M, que é um material restaurador universal para dentes anteriores e posteriores, evolução da resina Z100, que teve a matriz orgânica modificada, onde grande parte do monômero TEGDMA foi substituído por uma mistura de UDMA e Bis-EMA(6). Segundo o fabricante, o TEGDMA possui um peso molecular relativamente baixo, e juntamente com o alto número de duplas ligações por unidade de peso, proporcionam um alto grau de ligações cruzadas, que se traduz clinicamente por um compósito rígido e denso, com alta contração ${ }^{40}$. Além disso, este monômero, relativamente hidrófilo e instável, pode contribuir para o espessamento ou amolecimento do compósito. Com a substituição de grande parte deste componente, por monômeros de alto peso molecular e, conseqüentemente com poucas duplas ligações, há uma menor contração de polimerização (cerca de 18\%, comparada à Z100), menor absorção de água pela maior hidrofobia, maior tempo de vida útil e uma matriz orgânica mais maleável. A carga inorgânica permaneceu essencialmente a mesma, constituída pela mesma classe de partículas sintéticas arredondadas de zircônia/sílica, realizando-se modificações no processamento das partículas para maximizar a consistência. A distribuição do tamanho das mesmas é de $0,01 \mu \mathrm{m}$ a $3,5 \mu \mathrm{m}$, sendo a média de 0,6 $4 \mathrm{~m}$, havendo um maior número de partículas pequenas em relação à resina Z100. Para esta investigação científica, pouca literatura foi encontrada a respeito da 
resina composta Filtek Z250, e escolheu-se este material restaurador aplicado na forma direta devido ao fato de ser uma evolução do material restaurador Z100.

Além disso, padronizou-se a utilização de somente um sistema adesivo para todos os grupos, que foi o de marca comercial Single Bond da $\mathbf{3 M}$, apresentado na forma de frasco único, contém como solventes a água e o álcool. O sistema adesivo, a resina composta direta e o cimento resinoso foram do mesmo fabricante, havendo então, uma compatibilidade entre eles. Segundo o fabricante, a resistência adesiva do Single Bond varia de $28 \mathrm{mPa}$ em dentina a $32 \mathrm{mPa}$ em esmalte, e apresenta ainda uma espessura de $12 \mu \mathrm{m}$, que favorece uma boa adaptação das restaurações. Apesar da resistência adesiva à dentina ser geralmente menor em relação ao esmalte $^{86}$, na maioria dos casos, a área de superfície de dentina é consideravelmente maior que a de esmalte ${ }^{116}$, que ocorre também nos preparos cavitários realizados neste estudo. $E A K L E^{33}$, em 1986, avaliou a resistência à fratura de dentes com preparos cavitários classe II, MOD, restaurados com resina composta direta comparando a média dos valores obtidos pelos grupos que tiveram associados o condicionamento ácido e adesivo somente de esmalte, com dentes que tiveram associados o condicionamento ácido de esmalte e adesivos de esmalte e dentina. Verificou-se que os valores apresentados pelo grupo que teve associado o adesivo de esmalte e dentina foram significantemente maiores, devido à ocorrência de uma área de união mais efetiva entre o material restaurador e os tecidos dentários. O sistema adesivo utilizado no presente estudo contém "primer" e adesivo num frasco único, que são utilizados em conjunto com a técnica do ataque ácido total, em que esmalte e dentina são condicionados. No esmalte haverá a formação de microporosidades, promovendo um aumento na área de superfície e 
capacidade de umectação, melhorando em muito a retenção neste substrato ${ }^{12,30}$. Em dentina, o condicionamento ácido se faz necessário para os sistemas adesivos atuais, removendo toda a "smear layer", e promovendo uma desmineralização da dentina inter e peritubular ${ }^{60}$, e expondo a trama de fibras colágenas, que vai permitir a interpenetração e impregnação do monômero hidrofílico neste substrato, possibilitando o preenchimento do agente adesivo em toda esta área ${ }^{86}$, para formar assim a chamada camada híbrida ${ }^{79,80}$.

JOYNT et al. ${ }^{59}$, em 1987 afirmaram não encontrar diferença estatística quando se compararam os resultados apresentados pelos grupos restaurados com resina composta e com amálgama. Justificou-se que a média dos valores apresentados pelo grupo restaurado com resina composta não foi maior, devido ao fato de que não se utilizou uma técnica de aplicação incremental e de não se ter utilizado um método correto de fotopolimerização. Muitos fatores podem afetar a contração de polimerização, como o tamanho da restauração, a configuração da cavidade e a técnica de inserção e de polimerização da resina composta ${ }^{105}$. WIECZKOWSKI JUNIOR et al. ${ }^{117}$ então, em 1988, com o intuito de avaliar as diferentes técnicas de inserção de resina composta, compararam o efeito da técnica do incremento único e a técnica incremental na resistência à fratura de dentes prémolares, utilizando-se de duas marcas comerciais. Verificaram que os dentes que foram restaurados pela técnica incremental apresentaram as maiores médias de resistência à fratura, em qualquer das marcas comerciais avaliadas. $\boldsymbol{E I C K}^{36}$, em 1986, através de exame em microscópio eletrônico, verificou a presença de fendas ao longo da resina composta, quando inserida na forma de incremento único, 
provavelmente devido à contração de polimerização, o que não foi observado quando se inseriu através da técnica incremental.

A forma de inserção da resina composta direta nesta investigação foi realizada através de pequenos incrementos, baseada na mesma técnica incremental proposta, onde se procurou seguir o princípio básico de não se polimerizar resina composta contra as margens opostas ao mesmo tempo, ou seja, primeiro um incremento foi fotopolimerizado contra uma parede e somente depois, num segundo momento, um outro incremento foi aplicado e fotopolimerizado. A técnica incremental empregada procurou então manter o fator de configuração cavitária (fator C) o mais baixo possível, que corresponde à relação entre superfícies aderidas e as não aderidas, através da qual pode-se prever a possibilidade da ocorrência de destacamento na interface dente-restauração ${ }^{25}$, pela falha coesiva da camada híbrida devida à ação das forças geradas pela contração de polimerização ${ }^{113}$. Considerando-se ainda este fator, foi realizada a polimerização gradual, por vestibular e lingual, utilizando-se das estruturas dentárias remanescentes, que diminuíram a intensidade de luz que atingia a resina composta, como proposto por LÖESCHE ${ }^{68}$, em 1999. Realizando-se uma polimerização mais lenta e progressiva, ou seja, uma polimerização gradual, ocorre uma maior possibilidade de escoamento da resina havendo um relaxamento das tensões na interface dente-restauração ${ }^{25}$. Após a conclusão das restaurações, realizou-se então, por oclusal e pelas proximais, uma polimerização complementar. Estes procedimentos possibilitaram contornar o problema da contração de polimerização, pois dependendo de sua magnitude, haverá influência na intensidade das tensões geradas durante o endurecimento da resina composta. Parte destas tensões é compensada pela expansão higroscópica 
sofrida pela matriz orgânica das resinas compostas ${ }^{78}$. Uma vez exposta à água, a restauração absorverá este solvente, que, ao contrário da contração que é rápida e que ocorre em segundos, é um processo lento e que demora dias ${ }^{25,106}$. A absorção de água é máxima nos seis primeiros dias, havendo um equilíbrio após este período, que permanece inalterado até o décimo dia e varia de acordo com a configuração da restauração e com o material utilizado ${ }^{51,82}$. Optou-se então pela realização dos testes de compressão axial, após um período de sete dias, com o intuito de se compensar, pelo menos em parte, a contração de polimerização pela expansão higroscópica que o material sofreria.

Os valores de resistência à fratura do grupo 4, restaurados com resina composta na forma direta, apresentaram uma média de 147,59 kgf. Este resultado mostrou um valor intermediário entre o grupo 1, controle, e o grupo 2, que recebeu preparos cavitários e não foram restaurados. Sendo assim, da análise estatística dos resultados, verificou-se que não houve diferença estatística entre os grupos 2 e 4, nem entre os grupos 1 e 4 . Apesar de o grupo 2 apresentar valores de resistência numericamente maiores que o grupo 3, que recebeu preparos com paredes divergentes, ao se restaurar com resina composta na forma direta, houve um restabelecimento da resistência à fratura em não mais que $76 \%$ dos valores apresentados pelo grupo de dentes intactos, apesar de não haver diferença estatística entre eles.

JOYNT et al. ${ }^{59}$, LANDY; SIMONSEN ${ }^{62}$ e BAKKE et al. ${ }^{6}$ encontraram valores semelhantes, não obstante as diferenças na metodologia e materiais avaliados. A resistência à fratura de dentes restaurados com amálgama e resina composta, comparados com dentes hígidos, foi realizado por STAMPALIA et al. ${ }^{104}$, em 1986. 
Estes autores encontraram valores semelhantes de resistência, entre as médias dos grupos preparados e restaurados, independente do material restaurador utilizado. Estes valores chegaram a $61 \%$ da média dos valores encontrados no grupo-controle, havendo diferença estatística significante entre grupos de dentes restaurados e o de dentes intactos. Num experimento realizado por MORIN; DELONG; DOUGLAS ${ }^{77}$, em 1984, foi avaliada a flexão cuspídea através de testes não destrutivos de carregamento axial. Verificaram que dentes com preparos cavitários de 1/4 da distância intercuspídea e que receberam restaurações adesivas de resina composta autopolimerizável tiveram a sua rigidez restabelecida em cerca de $88 \%$ dos valores apresentados pelo controle de dentes íntegros. REEL; MITCHELL ${ }^{91}$, em 1989, avaliaram a resistência à fratura de dentes pré-molares que receberam preparos classe II, MOD, com metade da distância intercuspídea, tendo a caixa oclusal uma profundidade de $3 \mathrm{~mm}$, variando-se a presença ou não de bisel no cavo superficial na caixa proximal, sistema adesivo utilizado e ainda, o tipo de polimerização do material. Observaram que, independente do sistema adesivo aplicado, a resistência à fratura dos dentes restaurados com resina composta na forma direta correspondeu à cerca de metade dos valores apresentados pelo grupo controle, que foi de dentes hígidos.

Na presente investigação, houve um aumento de $36 \%$ na resistência à fratura dos dentes, ao restaurá-los com resina composta quando comparados aos dentes que receberam somente preparos cavitários, sem serem restaurados. No estudo de; MISHELL; SHARE; NATANSON ${ }^{96}$, em 1982, observaram um aumento de $38,5 \%$ quando restauraram dentes pré-molares superiores enfraquecidos por preparos de 1/3 ou mais da distância entre as cúspides quando restaurados com resina 
composta. Já LIBERMAN et al. ${ }^{66}$, em 1990, verificaram um aumento de $33 \%$ na resistência dos dentes pré-molares, que receberam preparos com paredes circundantes remanescentes com $2 \mathrm{~mm}$ de espessura e parede pulpar com profundidade de $4 \mathrm{~mm}$.

Os padrões de fratura mostrados pelos corpos de prova do grupo 4 foram bem homogêneos, sendo que a maioria deles apresentou fratura de cúspides palatinas, com a restauração permanecendo quase intactas visualmente, aderidas à estrutura dentária (Figura 40). A resina composta na forma direta foi capaz de suportar as forças que atuaram sobre as cúspides, mantendo-se quase que integralmente pela menor resiliência em relação às resinas indiretas, sendo que a cúspide palatina fraturou quase sempre da mesma forma. Pela configuração dos preparos cavitários realizados nos grupos 2 e 4, ocorreu um desgaste maior na base da cúspide, sendo ainda mais fragilizada pelas caixas proximais que foram bastante extensas. Como nos testes de compressão, ocorreu a ação das forças sobre os dentes e não sobre as restaurações, as cúspides palatinas, provavelmente por serem menos volumosas que as vestibulares, foram mais fragilizadas nos preparos, sendo as que mais fraturaram. A característica do preparo cavitário realizado no grupo 4, possibilitou um maior volume de esmalte e dentina nas cúspides, que foi justamente, pela própria característica de friabilidade destas estruturas orgânicas, o ponto fraco neste grupo de dentes, como mencionado por STAMPALIA et al. ${ }^{104}$, em 1986, enfatizando que, apesar de haver uma redução da flexão das cúspides, a resistência à fratura foi mais dependente do remanescente da estrutura dentária do que do material restaurador em si. O esmalte possui baixa resistência à compressão, sendo altamente anisotrópico, ou seja, é capaz de reagir 
diferentemente, de acordo com a direção da propagação das forças mastigatórias ou de compressão. A dentina é menos anisotrópica, apresentando padrão de fratura mais freqüentemente perpendicular aos túbulos dentinários ${ }^{91}$, como observado na presente investigação. As cúspides mais freqüentemente envolvidas foram as palatinas, diferentemente do que quando se avaliou o padrão de dentes que receberam somente preparos cavitários, onde a cúspide mais envolvida é a vestibular $(70 \% \text { dos casos })^{96}$ por se tornarem mais alongadas, além do que, clinicamente, não há diferença na freqüência de fratura entre elas ${ }^{26}$, ou uma leve tendência à maior freqüência de fratura da cúspide vestibular ${ }^{13,35}$.

As resinas compostas são amplamente utilizadas em dentes posteriores, e apesar dos frustrantes resultados inicialmente obtidos quando de sua aplicação, houve uma grande evolução em relação às suas propriedades físicas e mecânicas. As deficiências iniciais nas resinas compostas, tais como o desgaste, pouca adesão à dentina e a contração de polimerização foram minimizados, resultando em importantes melhoras nas propriedades físicas e químicas nos sistemas de resinas do mercado, além da habilidade em se aderir à estrutura dentária. Trabalhos in vivo, demostraram que a perda vertical de material restaurador nas resinas atuais, é em alguns casos, similar ao esmalte ${ }^{119}$. Apesar disso, segundo a American Dental Association $^{2}$ (1994), as resinas compostas estão bem indicadas em preparos de classe I e II conservativas, estando contra-indicadas em cavidades muito extensas ${ }^{1}$.

Assim, as restaurações na forma indireta foram desenvolvidas com dois propósitos básicos: reduzir a formação de fendas na interface dente/restauração, tendo em vista que a maior parte do material já estaria polimerizado, e aumentar a resistência ao desgaste devido a uma polimerização mais eficiente, melhorando 
assim as propriedades mecânicas e a performance clínica deste material restaurador $^{101}$.

Apesar de alguns trabalhos mostrarem em laboratório ${ }^{115}$ que houve um aumento na resistência ao desgaste em cerca de 70\%, o mesmo não foi observado em alguns trabalhos clínicos ${ }^{89,116,119}$. As resinas utilizadas quando da idealização da técnica, apesar de apresentarem algumas vantagens significativas, mostraram uma série de limitações importantes como inadequada resistência necessária para suportar forças oclusais e de flexão, desgaste acentuado, fraturas de margem e de istmo e a instabilidade de cor. Em meados dos anos 90, com o desenvolvimento da segunda geração dos sistemas de resinas indiretas, houve uma melhora significativa nas propriedades mecânicas destes materiais ${ }^{108}$. Enquanto que os materiais da primeira geração de sistemas de resina indireta continham uma maior porcentagem em volume de matriz orgânica, os sistemas de segunda geração contêm uma maior porcentagem em volume de carga inorgânica, havendo a adição de partículas de cerâmica, que contribuiu para um aprimoramento das propriedades físicas das restaurações.

Ambos sistemas de resina indireta utilizados nesta investigação são resinas compostas híbridas e contêm partículas inorgânicas incorporadas (com até 85\% de carga) em uma matriz de metacrilatos bifuncionais como BIS-GMA, UDMA, TEGDMA ou uma mistura deste monômeros e ainda metacrilatos multifuncionais. Na formulação do Artglass (Kulzer), há de quatro a seis grupamentos funcionais que permitem que aconteça um maior número de conversões em duplas ligações, que faz com que haja um entrelaçamento maior, com a conseqüente maior estabilidade $^{42}$. Esta característica possibilita uma maior resistência ao desgaste e 
influencia nas propriedades mecânicas da resina ${ }^{65}$. As partículas inorgânicas deste material são compostas basicamente de vidros de bário, além de sílica coloidal em menor quantidade. São de forma geral denominados de polímeros de vidro. Já a resina composta Targis (Ivoclar), possui uma matriz inorgânica composta de vidro de bário silanizado, óxidos mistos silanizados e dióxido de silício. Este material é denominado cerômero, denominação que recebem as resinas otimizadas com partículas cerâmicas ${ }^{39}$.

O material cerâmico utilizado no grupo 7, classificado como vidro ceramizado, tem os cristais de leucita distribuídos uniformemente em uma fase vítrea, que faz com que, através dos processos de inclusão e cocção, apresente grande homogeneidade. Esta característica é extremamente importante porque não vai apresentar porosidades visíveis, que é o fator negativo presente nas porcelanas de modo geral, pois estas porosidades favorecem a propagação de trincas ao longo do material. Melhorias na resistência flexural foram alcançadas por IPS Empress (Ivoclar), que teve aumentado o conteúdo de cargas inorgânicas, além do refinamento do tamanho das partículas, permitindo alta resistência à compressão, havendo um aumento na resistência à flexão e à tração, sendo as porcelanas deficientes nestas propriedades até então ${ }^{4,53}$.

Os grupos 5 e 6 receberam preparos cavitários da mesma forma que foram realizados no grupo 3 e foram então restaurados com resina composta na forma indireta, respectivamente, Artglass e Targis. Os resultados dos testes de compressão apresentados por estes grupos, mostraram médias de valores de 184,15 e 183,81 kgf, valores bem próximos aos apresentados pelo grupo controle, não havendo diferença estatística entre eles. Pode-se observar que houve um 
grande potencial destes materiais restauradores em se restabelecer a resistência à fratura de dentes com preparos.

Além dos grupos de dentes mencionados, finalmente, o grupo 7 recebeu preparos cavitários da mesma forma como foram realizados no grupo 3, sendo restaurados com restaurações de porcelana, da marca comercial IPS Empress. Os valores de resistência apresentados pelo grupo 7 tiveram uma média de 181,12 kgf, bem próximos às médias apresentadas pelos grupos 5 e 6.

De forma geral, não se encontrou diferença significante na resistência à fratura entre dentes que receberam restaurações indiretas e o grupo de controle. Os resultados obtidos no presente estudo são embasados por vários trabalhos na literatura $^{6,59,62,67,74,81,83,88,95}$ como o de OLIVEIRA ${ }^{83}$, que, em 1998, avaliou a resistência à fratura de dentes que receberam restaurações indiretas de resina composta e porcelana. Este autor confeccionou preparos cavitários amplos, com 2/3 da distância intercuspídea e comparou os valores obtidos pelos grupos restaurados nos testes de compressão a um grupo controle (positivo) de dentes hígidos e a um grupo de dentes que recebeu somente preparos cavitários (controle negativo). Os resultados mostrados pelo grupo de dentes preparados que permaneceram sem serem restaurados foram significantemente menores que os apresentados pelo grupo de dentes hígidos, enquanto que os grupos de dentes restaurados com restaurações adesivas indiretas tiveram a sua rigidez inicial restabelecida. BRUNTON et al. ${ }^{11}$, em 1999, compararam a resistência à fratura de dentes que receberam restaurações indiretas de resina composta e porcelana. Foram realizados preparos em pré-molares superiores que receberam restaurações de cerâmica (IPS Empress) e restaurações indiretas de resina composta (Belle Glass e SR Isosit). 
Puderam verificar que os materiais restauradores foram capazes de restabelecer a resistência à fratura a valores próximos e até maiores aos apresentados pelo grupocontrole (hígidos).

Em 1987, JENSEN et al. ${ }^{58}$ compararam a resistência de dentes que receberam preparos cavitários com 1/3 da distância intercuspídea e restaurações diretas de resina composta e restaurações indiretas de porcelana. Estes autores realizaram testes não destrutivos em que avaliaram a rigidez dos dentes após o preparo cavitário e após os procedimentos restauradores. Além disso, realizaram testes destrutivos de compressão para se avaliar a resistência à fratura. Nos testes de carregamento axial, verificaram valores para os dentes restaurados com restaurações indiretas de porcelana maiores que os do grupo de dentes com restaurações diretas, havendo diferença estatística. Justificou-se esta diferença devido ao fato de as porcelanas apresentarem uma reduzida elasticidade, quando comparadas às resinas compostas, que faz com se reduza ainda mais a flexão das cúspides. Quando se comparou a resistência à fratura, verificou-se que não houve diferença estatística entre os valores apresentados pelos grupos restaurados e o grupo controle, de hígidos.

Uma outra investigação onde se utilizaram testes não destrutivos, foi a realizada em 1991 por LOPES; LEITAO; DOUGLAS ${ }^{67}$, em que realizaram medições progressivas da rigidez apresentada pelos dentes quando hígidos, após receberem os preparos cavitários (com metade de distância intercuspídea) e após então serem restaurados com resina composta na forma indireta. A rigidez dos dentes, após a realização dos preparos cavitários, correspondeu a somente $33 \%$ da inicial. Puderam constatar que quando se utilizaram os sistemas adesivos, associados aos 
procedimentos restauradores indiretos, houve o restabelecimento de $97 \%$ da rigidez mensurada inicialmente, quando intactos, não apresentando diferença estatística. Os autores mostraram-se "surpresos" com a habilidade das restaurações indiretas em recuperar a rigidez dos dentes, mencionando que este fato poderia ser explicado não somente pela alta resistência adesiva obtida entre a restauração e os tecidos dentários, mas também pelo alto grau de rigidez do material restaurador após os mecanismos de fotopolimerização complementar.

Outro artigo, publicado por WATTS; WILSON; BURKE ${ }^{114}$, em 1995, relatou a metodologia e os resultados obtidos nos testes de resistência à fratura de dentes que receberam restaurações indiretas de resina composta. Compararam-se os resultados, através da variação das dimensões dos preparos, com $1 / 3$ e $1 \frac{1}{2}$ da distância intercuspídea e com 3, 4 e $5 \mathrm{~mm}$ de profundidade. Houve algumas diferenças na metodologia, pois não foi utilizada a técnica do ataque ácido total, realizando-se condicionamento apenas de esmalte e aplicando-se adesivo de esmalte, em conjunto com o agente cimentante de dupla polimerização. Além disso, para os testes de compressão acoplou-se um cilindro de aço de $4 \mathrm{~mm}$ de diâmetro que contatava os materiais restauradores, não sendo avaliada diretamente a resistência à fratura dos dentes. O grupo de dentes que apresentou os maiores valores de resistência foi o que recebeu preparos com 1/2 da distância intercuspídea, com profundidade de $4 \mathrm{~mm}$. Estes resultados contrariaram os valores encontrados na literatura, que tem reforçada a afirmação de que se realizando preparos com menores dimensões, a resistência fica menos prejudicada. No estudo publicado em 1990, por DIETSCHI et al. $^{32}$, relataram-se os valores encontrados nos testes de resistência à fratura de dentes terceiro molares, nos quais foram confeccionados 
preparos cavitários com abertura de istmo oclusal de $2,5 \mathrm{~mm}$ e profundidade nas mesmas dimensões. Estes dentes receberam restaurações indiretas de porcelana, variando-se as marcas comerciais e os cimentos utilizados (resinoso e de ionômero de vidro). Os maiores valores de resistência foram os apresentados pelos grupos que tiveram as restaurações cimentadas por cimento resinoso, sendo que a cerâmica da marca comercial Vitadur $\mathrm{N}$ apresentou os melhores resultados. Estes dados confirmaram que a união dos cimentos ionoméricos à porcelana era ineficiente e são corroborados pelos resultados demonstrados em outros estudos $^{22,34,52,72,98}$. Neste estudo ainda, também não foram utilizados adesivos dentinários, sendo que os valores de resistência máxima apresentados pelos grupos restaurados foram de não mais que $76 \%$ da média dos valores apresentados pelo grupo-controle.

O padrão de fratura apresentado pelos grupos de restaurações indiretas foi bem diferente do que o apresentado pelo grupo 4. Os grupos 5 e 6, restaurados com resina indireta tiveram padrões de fratura mais severos, incluindo pelo menos uma das cúspides, principalmente a palatina, com envolvimento de grande parte da restauração (Figuras 41 e 42). O material restaurador geralmente se destacou quando ocorreu a fratura de cúspide, ocorrendo então falhas adesivas na interface dente-cimento resinoso, mas que ocorreram quando apresentando altos valores de resistência, próximos aos valores apresentados pelo grupo de hígidos. Os preparos cavitários realizados para os grupos de restaurações indiretas possuíam paredes divergentes que favorecem a fratura por ação de separação das cúspides (exercido pelo cilindro) e, apesar disso, tiveram os valores de resistência restabelecidos por ação dos materiais restauradores, que se mantiveram fortemente aderidos ao dente. 
O grupo 7 foi o que apresentou os padrões de fratura mais severos, sendo que os corpos de prova que apresentaram os maiores valores, houve a destruição quase que completa do dente (Figura 43). A maioria dos corpos de prova apresentaram destruição da cúspide palatina, havendo destacamento de quase toda restauração. MAK; QUALTROUGH; BURKE ${ }^{70}$, em 1997, compararam a resistência à fratura e o padrão de fratura de dentes restaurados com porcelana feldspática (Mirage), porcelana aluminizada (Vitadur N), cerâmica infiltrada de vidro (Dicor) e vidro ceramizado (IPS Empress). Observaram um padrão de fratura mais severo (modo V) no grupo restaurado com IPS Empress em $40 \%$ da amostra, enquanto que no grupo restaurado com Vitadur $\mathrm{N}$ encontraram-se $10 \%$ deste padrão, sendo que estes grupos apresentaram os maiores valores de resistência. Nos demais grupos não foi encontrado este padrão de fratura. Afirmou-se que a maior ocorrência de fraturas severas ocorrida no grupo restaurado com IPS Empress foi devido à transmissão maior das forças de compressão ao dente, possivelmente devido a uma maior adesão que ocorreu à estrutura dentária. Mais ainda, cerca de $60 \%$ das fraturas ocorreram na interface dente-cimento resinoso e em nenhum dos casos na interface cerâmica-cimento. BURKE et al. ${ }^{21}$, em 1993, afirmaram que a ocorrência de maior número de fraturas severas dificultaria a recuperação do remanescente, se este padrão ocorresse clinicamente. Já que os valores apresentados se aproximam da média dos valores apresentados pelo grupo controle, é pouco provável que ocorra este padrão in vivo. Diferentemente do grupo 4 , em que a resistência à fratura foi mais dependente das características orgânicas do remanescente, nos grupos que receberam restaurações indiretas (grupos 5, 6 e 7), a resistência foi 
influenciada pelas propriedades mecânicas dos materiais restauradores e da alta adesividade dos mesmos à estrutura dentária.

Como se pode observar, há vários fatores relacionados quando se quer aprimorar a resistência à fratura dos dentes ao serem restaurados. O processo de adesão dos materiais restauradores à estrutura dentária é um dos mais importantes, pois como se observa nos resultados, os valores obtidos pelos grupos que receberam restaurações indiretas no presente estudo apresentaram valores semelhantes aos exibidos pelo grupo controle. Segundo ANUSAVICE ${ }^{4}$, esse mecanismo de adesão corresponde à união de dois substratos dissimilares; no caso os substratos envolvidos são a estrutura dentária e o material restaurador entre os quais estarão interpostos o sistema adesivo (nas restaurações diretas e indiretas) e o cimento resinoso (nas restaurações indiretas). As variações regionais dos tecidos dentários determinam uma não uniformidade da adesão e vão interferir diretamente na qualidade adesiva de materiais restauradores que podem ser afetados por prolongadas exposições a forças de tração e compressão. A eficácia de um sistema adesivo vai estar então na dependência de sua maior ou menor sensibilidade a estas variações do substrato ${ }^{24,60}$.

O processo de adesão que ocorre nos tecidos dentários é, então, um mecanismo micromecânico, sendo que quando o adesivo Single Bond é corretamente aplicado em duas camadas, ocorre a penetração dos monômeros adesivos nas microporosidades formadas no esmalte e a formação da camada híbrida na intimidade da dentina, que tem uma espessura de 2 a $7 \mu \mathrm{m}$, segundo FERRARI; GORACCI; GARCIA-GODOY"1, ocorrendo ainda a formação de "tags" de resina. 
Nos sistemas restauradores diretos, uma vez obtida a camada híbrida, ocorrerá uma união da resina composta ao adesivo, havendo ligações químicas entre os radicais metacrilatos. Os sistemas restauradores indiretos por sua vez, necessitam de um preparo prévio à cimentação, havendo necessidade do aumento da energia de superfície, para que se obtenha a adesão química e micromecânica. Em relação às resinas compostas, a polimerização vai ser muito efetiva e uma melhora nas propriedades mecânicas é obtida pelo material, através do alto grau de conversão dos monômeros em polímeros. Assim vai haver um reduzido número de radicais para a ocorrência de união química, necessitando-se da criação de microrretenções mecânicas para que uma adesão efetiva aos tecidos dentários possa ocorrer ${ }^{104}$.

Realizou-se nos sistemas de resina indireta e nas porcelanas este tratamento interno, inicialmente através da aplicação de jateamento com óxido de alumínio, com $50 \mu \mathrm{m}$ de espessura, que tem a função de promover uma limpeza superficial e a formação de microrretenções ${ }^{64}$. Após a realização deste passo operatório, foi realizada a aplicação de ácido fosfórico na superfície interna das restaurações de resina composta indireta, como uma ação meramente de limpeza, removendo sujidades e restos de partículas remanescentes do jateamento. Já nas restaurações indiretas de porcelana, aplicou-se ácido fluorídrico, para aumentar a área de superfície aderida e criar porosidades. Optou-se pela não aplicação de ácido fluorídrico na superfície interna das restaurações de resina indireta devido ao fato de alguns trabalhos, como o de SWIFT JUNIOR et al. ${ }^{107}$, afirmarem que a aplicação deste ácido, mesmo em curtos períodos, pode causar dissolução das partículas inorgânicas expostas e um possível amolecimento da matriz orgânica, além da 
absorção do ácido atravessando a superfície. Estas afirmações foram confirmadas por LATTA; BARKMEIER ${ }^{64}$,1994, e HUMMEL et al. ${ }^{55}$,1997. Mais ainda, segundo estes estudos, há uma menor resistência adesiva quando se associa a aplicação do ácido fluorídrico à superfície da resina composta indireta, sendo confirmado por estudos como os de STOKES et al. ${ }^{105}, 1993$ e SHORTALL; BAYLIS; WILSON ${ }^{100}$, 1996. Outro passo operatório de importância que foi realizado em relação à superfície interna das restaurações indiretas foi a silanização. Os silanos são substâncias que contêm radicais sílicofuncionais que promovem a adesão química aos radicais inorgânicos das resinas indiretas e das porcelanas e radicais organofuncionais, que copolimerizam com a matriz orgânica do cimento resinoso ${ }^{3} .0$ silano utilizado neste estudo foi o Ceramic Primer da $3 \mathbf{M}$ que é pré-hidrolizado, pronto para o uso, sendo pincelado diretamente sobre a superfície interna da restauração. Vários estudos confirmam que se verifica uma maior resistência adesiva ao se associar o jateamento da superfície interna das restaurações indiretas com a utilização do silano ${ }^{64,84,105,107}$.

Outro fator a ser analisado é em relação à chamada fixação propriamente dita das restaurações indiretas. A utilização do cimento resinoso tem papel primordial na obtenção da adesão ${ }^{14,15}$. Além disso, as propriedades físicas do agente cimentante de escolha combinado com o sistema adesivo farão com que haja a correlação entre as propriedades físicas e mecânicas dos materiais restauradores que vão estar aderidos à superfície dentária ${ }^{4}$. O cimento vai exercer um papel significativo auxiliando na obtenção dos altos valores de resistência de fratura que ocorreram nos grupos 5, 6 e 7, possibilitando uma alta resistência de união à dentina e ao esmalte, conferindo assim um grande sinergismo entre material restaurador, cimento resinoso 
e o dente. O Cimento Resinoso Adesivo Rely $\mathbf{X}$ da 3M é um material recém lançado no mercado para cimentação permanente, de mistura pasta-pasta, de ativação dual, indicado para restaurações estéticas indiretas. Segundo o perfil técnico do fabricante ${ }^{109}$, houve a adição de um polímero derivado do dimetacrilato que modifica a reologia do material, melhorando assim as propriedades do mesmo e as características de manipulação. Além de suas propriedades, a proporção das pastas é realizada precisamente por um dispensador (Clicker Dispenser) sendo que as propriedades de manipulação facilitam o carregamento do cimento nas restaurações, diminuindo-se a pressão de cimentação. Para que se obtivesse uma padronização da espessura do cimento, todos os passos operatórios pertinentes à fixação foram rigorosamente seguidos, mantendo-se a pressão de cimentação através de um aparato cujo peso era de $500 \mathrm{~g}^{85}$, apesar de se encontrar na maioria dos trabalhos a inserção através de uma moderada pressão digital ${ }^{14,18,19,32,58}$.

As propriedades físicas e mecânicas dos materiais restauradores analisados são também requisitos de fundamental importância na resistência à fratura dos dentes. Além da adesão à estrutura dentária através dos agentes cimentantes e/ou sistemas adesivos, devem apresentar forças coesivas, capazes de suportar as forças mastigatórias, devendo possuir propriedades físicas como coeficiente de expansão térmica, condutibilidade térmica e elétrica e mecânicas como dureza, resistência à flexão, módulo de elasticidade e resiliência de forma que contribuam para a performance clínica das restaurações. Segundo CRAIG; O'BRIEN; POWERS ${ }^{28}$, a capacidade de um material restaurador de suportar as forças mastigatórias baseia-se em três pilares básicos que são o módulo de elasticidade 
inerente do que é constituído o material utilizado, o volume do mesmo e ainda a forma.

Módulo de elasticidade está relacionado à rigidez e não constitui uma medida de resistência de um determinado material. Constitui uma propriedade que representa a capacidade de deformação sob tensão, e segue o princípio de que quanto mais baixo for a deformação para um determinado valor de tensão, maior será o valor do módulo de elasticidade ${ }^{4}$. Corresponde à deformação elástica do material, que clinicamente se traduz por uma maior ou menor resiliência, ou seja, uma maior ou menor elasticidade que o material terá. Quando sob tensão, dois substratos com valores suficientemente diferentes de módulo de elasticidade, unidos por um sistema adesivo, vão ter a concentração destas forças localizada nesta união entre eles ${ }^{24}$. Resistência à flexão é também uma importante propriedade com relação à resistência à deformação ou ruptura da restauração quando sob ação de forças oclusais, bem como a manutenção do selamento marginal. O esmalte e a dentina, apesar de apresentarem alto módulo de elasticidade, apresentam baixos valores de resistência à flexão, caracterizando-se por serem friáveis com reduzida resistência à compressão e à tração ${ }^{91}$.

O quadro apresentado a seguir apresenta valores relacionados às propriedades físicas dos materiais investigados no presente estudo: 
TABELA 6 - Quadro comparativo dos materiais restauradores *

\begin{tabular}{|c|c|c|c|}
\hline $\begin{array}{l}\text { Material } \\
\text { Restaurador }\end{array}$ & $\begin{array}{c}\text { partículas } \\
\% \text { peso }\end{array}$ & $\begin{array}{c}\text { Resistência } \\
\text { Flexural** }^{* *}\end{array}$ & $\begin{array}{l}\text { Módulo de ** } \\
\text { Elasticidade }\end{array}$ \\
\hline Filtek Z250 (3M) & 60 & 150 & 11.000 \\
\hline Artglass (Kulzer) & 72 & 120 & 9.000 \\
\hline Targis (Ivoclar) & 80 & $150-160$ & 10.000 \\
\hline IPS Empress (Ivoclar & 30 a 40 & $160-180$ & 60.000 \\
\hline Esmalte & & 20 & $40.800^{47}$ \\
\hline Dentina & & 75 & $13.600^{47}$ \\
\hline
\end{tabular}

A resina composta direta utilizada neste estudo apresenta uma resistência flexural menor que a cerâmica IPS Empress, maior que o Artglass e semelhante ao da resina composta indireta Targis. Além disso apresenta um módulo de elasticidade maior que as resinas indiretas, indicando ser menos resiliente que estas, caracterizando-se por ser friável quando em menor espessura, necessitandose de volume nas áreas de maiores esforços oclusais ${ }^{49}$. Apesar destes fatores, este material restaurador contribuiu para o aumento da resistência dos dentes e, em relação ao padrão de fratura, observando-se que as mesmas permaneceram na maioria dos casos intactas, ficando mais restritas à destruição da cúspide palatina.

O processo pelo qual ocorre uma polimerização mais efetiva nas resinas compostas indiretas, faz com que este material apresente uma resistência flexural melhorada e a resiliência aumentada, que se traduz clinicamente numa maior elasticidade e a uma maior resistência à fratura, que são características importantes para "inlays" e "onlays", uma vez que estão unidas à estrutura dentária através de materiais adesivos ${ }^{108}$. Outra propriedade importante é a dureza que é menor, que 
clinicamente corresponde a uma menor abrasão do dente antagonista em comparação às cerâmicas. Além disso, possuem grande capacidade de absorver forças de compressão, quando comparadas à porcelana ${ }^{31,48}$, reduzindo em $57 \%$ o impacto das forças oclusais, em comparação com as porcelanas. Ainda, apresentam uma baixa difusibilidade, pois o coeficiente de condutibilidade térmica é o que mais se aproxima do esmalte e da dentina ${ }^{61}$. O módulo de elasticidade é bem próximo ao da dentina, enquanto que o dos materiais cerâmicos é cerca de cinco vezes maior, o que neste caso, resultará em pequenas falhas na linha de cimentação e pequenas fraturas deste material ${ }^{45}$. De forma geral, são mais bem sucedidas em restaurações amplas que as resinas compostas na forma direta ${ }^{29}$.

As porcelanas transmitem quase que totalmente as forças mastigatórias à estrutura dentária. Além disso, as características deste material restaurador, como alto módulo de elasticidade, com maiores valores de resistência flexural em relação aos demais materiais utilizados, auxiliaram no restabelecimento da resistência à fratura a níveis altíssimos, mas contribuíram com que as forças para que as forças atuantes sobre os dentes causassem quase a completa destruição dos corpos de prova do grupo 7.

LOPES; LEITAO; DOUGLAS ${ }^{67}$ postulam que o fortalecimento da estrutura do dente por ação das restaurações adesivas, ligando e unindo as cúspides, possibilitando assim a longevidade dos dentes, indicando-se, desta forma, a realização deste tipo de restaurações para dentes com preparos cavitários extensos. Segundo LIBERMAN et al. ${ }^{66}$, as restaurações adesivas vão contribuir na melhor distribuição das forças pela estrutura dentária. Os dentes, ao serem submetidos à compressão, que atua verticalmente sobre as vertentes de cúspides, apresentam 
uma decomposição de forças laterais que se direcionam internamente e externamente. Este vetor interno, uma vez oposto pelo material restaurador, vai contribuir ativamente na distribuição destas forças, aumentando assim a resistência dos dentes.

Embora houvesse diferença nos valores numéricos quando se compararam as médias de resistência entre o grupo de dentes que recebeu restaurações diretas (grupo 4) e a dos grupos que receberam restaurações indiretas (grupos 5, 6 e 7), ao se realizar o tratamento estatístico dos resultados, observou-se que não houve diferença estatística entre eles, nem em relação ao grupo controle (grupo 1). Não houve diferença significante entre os grupos que receberam restaurações indiretas, havendo diferença significante com o grupo 3 (controle negativo), sendo que os valores apresentados pelo grupo 4 não apresentaram diferença estatística em relação ao grupo 2 (controle negativo). O grupo 6 apresentou os resultados mais homogêneos, comparáveis ao grupo controle, como observado na Figura 39.

A maior dificuldade na comparação com os demais trabalhos publicados foi em relação à metodologia empregada, variando-se a extensão e profundidade dos preparos, os materiais utilizados e ainda em relação mais propriamente aos testes de compressão. Muitos deles não realizaram controles positivos ou negativos, de forma que se impedisse a real análise dos resultados obtidos. O presente estudo procurou padronizar os diferentes preparos cavitários com as mesmas dimensões, que favoreceram a indicação de restaurações diretas e indiretas, que também seguiram um protocolo de forma que se pudesse eliminar um maior número de variáveis. Manteve-se uma regularidade dos preparos cavitários e escolheu-se 
apenas um sistema adesivo, além de um único agente cimentante, de forma que se avaliasse realmente a resistência à fratura dos dentes selecionados.

O padrão de fratura que ocorreu nos corpos de prova que receberam restaurações adesivas diretas ou indiretas forneceram importantes informações a respeito da resistência, pois analisando-se as características de como os dentes restaurados fraturam, é que se pode transpor dados de um trabalho experimental que se traduzirão em significância clínica. Além das propriedades dos materiais restauradores, a forma como os corpos de prova fraturaram, também dependerá da constituição orgânica dos dentes estudados, podendo identificar a localização do ponto fraco inerente da estrutura dentária. Embora tivesse ocorrido uma grande freqüência de fraturas que destruíssem em muito a estrutura dentária quando se restaurou com restaurações indiretas, pôde-se constatar realmente importância dos fatores discutidos. Os resultados obtidos, amplamente embasados na literatura, tornaram evidente a necessidade de se obter uma correta adesão dos materiais ao esmalte e à dentina, através dos sistemas adesivos, da relevância do tratamento interno da superfície das restaurações indiretas, da capital importância dos materiais restauradores com suas propriedades inerentes, e finalmente, da ação do agente cimentante que possibilitou a união destas propriedades às características orgânicas próprias dos tecidos dentários. As restaurações de resina composta na forma direta apresentaram valores numericamente menores que os demais grupos restaurados e do grupo controle, mas foi capaz de aumentar a resistência dos dentes preparados, que mostram padrões de fratura menos severos, permanecendo a restauração intacta na maioria dos casos. Além disso, permaneceram firmemente aderidas à estrutura dentária, demonstrando que as propriedades deste material são 
excelentes, sendo indicados para a restauração de dentes posteriores quando há preparos extensos. Os valores obtidos por todos os grupos avaliados foram bem maiores aos valores das forças mastigatórias que foram mensurados clinicamente, que variam de 19,5 a $81,7 \mathrm{kgf}^{50}$. É claro que as situações clínicas variam conforme o dente envolvido, devendo-se levar em conta uma série de fatores, mas as restaurações adesivas provaram ser eficientes, mostrando uma evolução contínua, que torna estimulante a busca de um material restaurador ideal, que nos forneça resistência, retenção, estabilidade, selamento marginal e estética, e acima de tudo, uma grande longevidade clínica para este dente. 


\section{CONCLUSÕES}




\section{7 - CONCLUSÕES}

De acordo com o estudo da literatura referente ao tema, levando-se em conta a metodologia aplicada e os materiais utilizados, com base na análise estatística dos resultados, pode-se concluir:

- que os preparos cavitários reduziram significantemente a resistência dos dentes;

- que não houve diferença significante na resistência dos dentes quando se compararam os diferentes tipos de preparo cavitário;

- que os materiais restauradores contribuíram para que esses valores aumentassem, não se observando diferença estatística entre os grupos 4, 5, 6 e 7 e o grupo controle;

- que houve um aumento significante na resistência quando se compararam os grupos 5, 6 e 7 (restaurações indiretas) em relação ao grupo 3 (preparado e não restaurado), o mesmo não sendo observado entre o grupo 4 (restauração direta) em relação ao grupo 2 (preparado e não restaurado). 
ANEXOS 


\section{ANEXOS}

\section{ANEXO A}

Grupo 1 - Grupo Controle - Hígidos

\begin{tabular}{|c|c|c|c|c|}
\hline Grupo/ C. P. & D.V.L. & D.M.D. & D.G.O. & R. F. \\
\hline $01 / 01$ & 9,6 & 7,4 & 8,8 & 184,50 \\
\hline $01 / 02$ & 9,3 & 7,3 & 7,5 & 210,50 \\
\hline $01 / 03$ & 9,0 & 7,1 & 7,4 & 183,25 \\
\hline $01 / 04$ & 9,6 & 7,4 & 8,8 & 211,00 \\
\hline $01 / 05$ & 9,3 & 7,4 & 7,2 & 238,25 \\
\hline $01 / 06$ & 8,9 & 7,4 & 7,7 & 189,50 \\
\hline $01 / 07$ & 9,6 & 7,4 & 8,5 & 169,75 \\
\hline $01 / 08$ & 8,9 & 7,0 & 7,0 & 164,75 \\
\hline Médias & 9,27 & 7,30 & 7,86 & 193,93 \\
\hline$D P$ & 0,31 & 0,16 & 0,72 & 24,46 \\
\hline
\end{tabular}

D.V.L. - Dimensão Vestíbulo-lingual

D.M.D.- Dimensão Mésio-distal

D.G.O.- Dimensão Gêngivo-oclusal

C.P. - Corpo de prova

DP - Desvio Padrão

R.F. - Valores de Resistência à fratura

continua... 
Continuação do Anexo A

Grupo 2 - Preparos Para Restaurações Diretas

\begin{tabular}{|c|c|c|c|c|}
\hline Grupo/ C. P. & D.V.L. & D.M.D. & D.G.O. & R. F. \\
\hline $02 / 01$ & 9,6 & 7,4 & 8,2 & 60,25 \\
\hline $02 / 02$ & 9,6 & 7,0 & 7,3 & 121,50 \\
\hline $02 / 03$ & 9,0 & 7,2 & 7,2 & 130,50 \\
\hline $02 / 04$ & 8,7 & 6,7 & 6,7 & 112,50 \\
\hline $02 / 05$ & 9,4 & 7,2 & 6,9 & 120,75 \\
\hline $02 / 06$ & 9,0 & 7,0 & 7,7 & 102,00 \\
\hline $02 / 07$ & 9,6 & 6,5 & 7,0 & 108,50 \\
\hline $02 / 08$ & 9,6 & 7,4 & 7,9 & 112,50 \\
\hline Médias & 9,31 & 7,05 & 7,36 & 108,56 \\
\hline$D P$ & 0,36 & 0,32 & 0,52 & 21,39 \\
\hline
\end{tabular}

Grupo 3 - Preparos Para Restaurações Indiretas

\begin{tabular}{|c|c|c|c|c|}
\hline Grupo/ C. P. & D.V.L. & D.M.D. & D.G.O. & R. F. \\
\hline $03 / 01$ & 8,6 & 6,0 & 6,8 & 87,25 \\
\hline $03 / 02$ & 9,3 & 6,7 & 7,8 & 71,75 \\
\hline $03 / 03$ & 9,2 & 6,9 & 8,2 & 70,00 \\
\hline $03 / 04$ & 8,9 & 6,0 & 6,9 & 95,00 \\
\hline $03 / 05$ & 9,3 & 6,7 & 7,0 & 112,25 \\
\hline $03 / 06$ & 9,2 & 7,2 & 8,1 & 114,75 \\
\hline $03 / 07$ & 9,6 & 6,8 & 7,3 & 110,50 \\
\hline $03 / 08$ & 9,6 & 7,2 & 7,2 & 102,00 \\
\hline Médias & 9,21 & 6,68 & 7,41 & 95,43 \\
\hline$D P$ & 0,33 & 0,46 & 0,54 & 17,73 \\
\hline
\end{tabular}


Continuação do Anexo A

Grupo 4 - Resina Composta Direta Filtek Z250

\begin{tabular}{|c|c|c|c|c|}
\hline Grupo/ C. P. & D.V.L. & D.M.D. & D.G.O. & R. F. \\
\hline $04 / 01$ & 9,6 & 7,4 & 8,2 & 115,25 \\
\hline $04 / 02$ & 9,6 & 7,4 & 7,5 & 169,25 \\
\hline $04 / 03$ & 9,5 & 7,4 & 7,5 & 185,00 \\
\hline $04 / 04$ & 9,5 & 7,4 & 6,6 & 184,25 \\
\hline $04 / 05$ & 9,5 & 6,8 & 7,5 & 165,00 \\
\hline $04 / 06$ & 9,5 & 7,1 & 7,0 & 115,00 \\
\hline $04 / 07$ & 9,6 & 7,4 & 7,3 & 104,75 \\
\hline $04 / 08$ & 9,1 & 7,1 & 7,5 & 142,25 \\
\hline Médias & 9,49 & 7,25 & 7,38 & 147,65 \\
\hline$D P$ & 0,16 & 0,22 & 0,46 & 32,63 \\
\hline
\end{tabular}

Grupo 5 - Resina Composta Indireta Artglass

\begin{tabular}{|c|c|c|c|c|}
\hline Grupo/ C. P. & D.V.L. & D.M.D. & D.G.O. & R. F. \\
\hline $05 / 01$ & 9,6 & 7,4 & 7,7 & 237,00 \\
\hline $05 / 02$ & 9,6 & 7,4 & 7,3 & 277,00 \\
\hline $05 / 03$ & 9,5 & 7,3 & 7,5 & 136,50 \\
\hline $05 / 04$ & 8,9 & 7,2 & 7,3 & 127,25 \\
\hline $05 / 05$ & 9,0 & 7,4 & 7,4 & 222,50 \\
\hline $05 / 06$ & 9,4 & 7,3 & 7,4 & 189,25 \\
\hline $05 / 07$ & 9,6 & 7,4 & 7,7 & 155,00 \\
\hline $05 / 08$ & 9,5 & 7,2 & 7,0 & 128,75 \\
\hline Médias & 9,39 & 7,32 & 7,41 & 184,15 \\
\hline$D P$ & 0,28 & 0,09 & 0,22 & 56,49 \\
\hline
\end{tabular}


Continuação do Anexo A

GRUPO 6 - Resina Composta Indireta Targis

\begin{tabular}{|c|c|c|c|c|}
\hline Grupo/ C. P. & D.V.L. & D.M.D. & D.G.O. & R. F. \\
\hline $06 / 01$ & 9,1 & 7,4 & 7,8 & 177,25 \\
\hline $06 / 02$ & 9,5 & 7,4 & 7,8 & 148,75 \\
\hline $06 / 03$ & 9,6 & 7,4 & 7,9 & 231,50 \\
\hline $06 / 04$ & 9,6 & 7,3 & 7,4 & 206,75 \\
\hline $06 / 05$ & 9,2 & 7,2 & 7,5 & 214,00 \\
\hline $06 / 06$ & 9,6 & 7,2 & 7,3 & 160,50 \\
\hline $06 / 07$ & 8,8 & 7,4 & 7,4 & 143,75 \\
\hline \multirow[t]{3}{*}{$06 / 08$} & 9,6 & 7,2 & 7,4 & 188,00 \\
\hline & 9,37 & 7,31 & 7,56 & 183,81 \\
\hline & 0,30 & 0,09 & 0,23 & 31,95 \\
\hline
\end{tabular}

Grupo 7 - Restaurações de Cerâmica IPS Empress

\begin{tabular}{|c|c|c|c|c|}
\hline Grupo/ C. P. & D.V.L. & D.M.D. & D.G.O. & R. F. \\
\hline $07 / 01$ & 9,3 & 7,4 & 8,0 & 145,25 \\
\hline $07 / 02$ & 8,9 & 7,2 & 6,8 & 142,00 \\
\hline $07 / 03$ & 9,6 & 7,3 & 7,5 & 197,25 \\
\hline $07 / 04$ & 9,6 & 7,4 & 7,6 & 136,50 \\
\hline $07 / 05$ & 9,2 & 7,3 & 7,0 & 203,75 \\
\hline $07 / 06$ & 9,2 & 7,2 & 6,6 & 238,50 \\
\hline $07 / 07$ & 9,5 & 7,4 & 6,7 & 227,00 \\
\hline $07 / 08$ & 9,6 & 7,2 & 7,3 & 158,75 \\
\hline Médias & 9,36 & 7,30 & 7,18 & 181,12 \\
\hline$D P$ & 0,25 & 0,09 & 0,49 & 40,49 \\
\hline
\end{tabular}




\section{ANEXO B}

\section{PERFIL TÉCNICO DOS MATERIAIS UTILIZADOS}

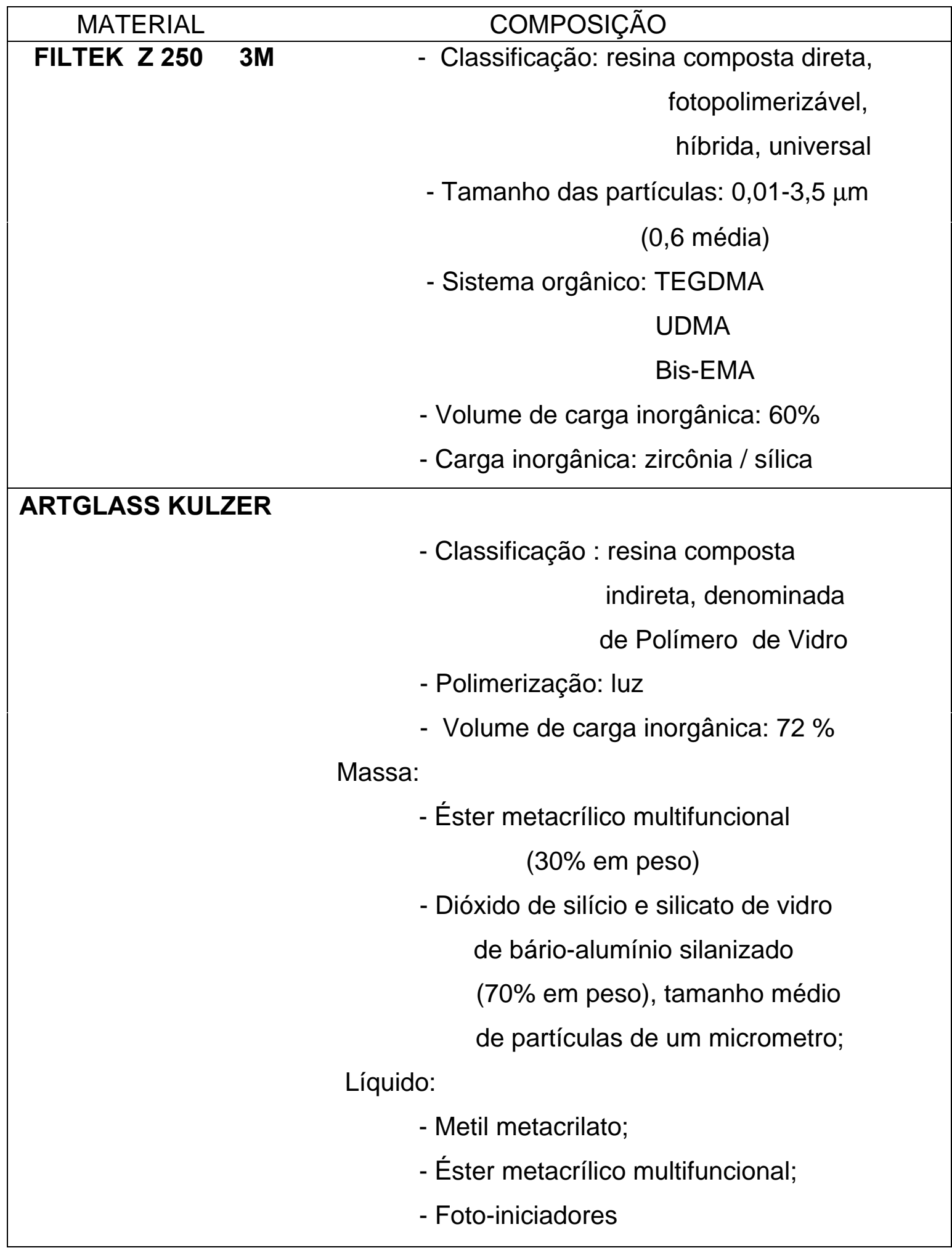

continua... 
Continuação do Anexo B

\section{PERFIL TÉCNICO DOS MATERIAIS UTILIZADOS}

\begin{tabular}{|c|c|}
\hline TARGIS IVOCLAR & $\begin{array}{l}\text { - Classificação: resina composta indireta, } \\
\text { denominada de cerômero } \\
\text { - Polimerização: Luz e calor à vácuo } \\
\text { - Volume de carga inorgânica: } 80 \text { \% } \\
\text { - Carga inorgânica: partículas de bário } \\
\text { - Tamanho das partículas: } 1 \mu \mathrm{m} \\
\text { - Sistema orgânico: Bis-GMA } \\
\text { Decandiol } \\
\text { Dimetacrilato } \\
\text { UDMA }\end{array}$ \\
\hline IPS EMPRESS IVOCLAR & $\begin{array}{l}\text { - Classificação: porcelana para } \\
\text { restaurações indiretas, } \\
\text { denominada vidro ceramizado } \\
\text { - Carga inorgânica: cristais de leucita } \\
\text { distribuídos numa matriz de vidro } \\
\text { - Volume de carga inorgânica: } 30 \text { a } 40 \% \\
\text { correspondente à fase cristalina } \\
\text { - Ciclo de cozimento: } 2 \text { minutos à } 850^{\circ} \mathrm{C} \\
\text { à vácuo }\end{array}$ \\
\hline
\end{tabular}

continua..... 
continuação do Anexo B

\section{PERFIL TÉCNICO DOS MATERIAIS UTILIZADOS}

SINGLE BOND 3M

- Classificação: sistema adesivo dental fotopolimerizável de frasco único

- 2-hidroximetilmetacrilato (HEMA)

- Bisfenol-A glicidilmetacrilato (BISGMA)

- Dimetacrilatos

- Sistema foto iniciador

- Copolímeros dos ácidos poli-acrílico e poli- itacônico

- Água

- Etanol

RELY X ARC 3M - Classificação: cimento resinoso adesivo

- material de mistura pasta-pasta

- ativação dupla (dual auto e foto)

- Bis-GMA

- TEGDMA

- Partículas inorgânicas de zircônia/sílica

- Pigmentos e auto e foto iniciadores 
REFERÊNCIAS

BIBLIOGRÁFICAS 


\section{REFERÊNCIAS BIBLIOGRÁFICAS*}

1- AMERICAN DENTAL ASSOCIATION. Council on Scientific Affairs. Statement on posterior resin-based composite. J. Amer. dent. Ass. , v. 129, n. 11, p. 1627-8, Nov. 1998.

2- AMERICAN DENTAL ASSOCIATION. Council on Scientific Affairs. Choosing intracoronal restorative materials. J. Amer. dent. Ass. , v. 125, n. 1, p. 102-3, Jan. 1994.

3- ANAGNOSTOPOULOS, T.; ELÍADES, G.; PALAGHIAS, G. Composition, reactivity and surface interactions of three dental silane primers. Dent. Mat., v. 9, n. 3, p. 182-90, May 1993.

4- ANUSAVICE, K. J. Estrutura da matéria e princípios de adesão. In: Phillips: materiais dentários. 10. ed. Rio de Janeiro, Guanabara Koogan, 1998. p. 8-17.

5- ARAÚJO, P. A.; CHIODI NETTO, J. Alterações na estrutura de amálgama dental, provocadas durante a inclusão de corpos de prova para metalografia. Estomat. Cult., v. 2, n. 2, p. 7-12, jul./dez. 1968.

*Normas recomendadas para uso no âmbito da Universidade de São Paulo, com base no documento "Referências Bibliográficas: exemplos", emanado do Conselho Superior do Sistema Integrado de Bibliotecas da U.S.P., em reunião de 20 de Setembro de 1990. 
6- BAKKE, J. C. et al. Fracture strenght of class II preparations with a posterior composite. J. dent. Res., v. 64, p. 350, 1985 . Special issue. / Abstract n. $1578 /$

7- BARABAN, D. J. The restoration of pulpless teeth. Dent. Clin. N. Amer., p. 633-53, Nov. 1967.

8- BELL, J. G. ; SMITH, M. C.; DE PONT, J.J. Cuspal failures of mod restored teeth. Aust. dent. J., v.27, n.5, p. 283-7, Oct. 1982.

9- BLASER, P. K. et al. Effects of designs of class 2 preparations on resistance of teeth to fracture. Oper. Dent. , v.8, n.1, p. 6-10, Winter 1983.

10- BOWEN, R. L. Properties of silica-reinforced polymer for dental restorations. J. Amer. dent. Ass. , v. 66, n.1, p. 57-64, Jan. 1963.

11- BRUNTON, P. A. et al. Fracture resistance of teeth restored with onlays of three contemporary tooth-colored resin-bonded restorative materials. J. prosth. Dent., v. 82, n. 2, p. 167-71, Aug. 1999.

12- BUONOCORE, M. G. A simple method of increasing the adhesion of acrylic filling materials to enamel surfaces. J. dent. Res. , v. 34, n. 6, p. 849-53, Dec. 1955.

13- BURKE, F. J. T. Tooth fracture in vivo and in vitro. J. Dent. , v. 20, n. 3, p. 1319, 1992.

14- BURKE, F. J. T. The effect of variations in bonding procedure on fracture resistance of dentin-bonded all-ceramic crowns. Quintessence Int., v. 26, n.4, p. 293-300, Apr. 1995. 
15- BURKE, F. J. T. Fracture resistance of teeth restored with dentin-bonded crowns: the effect of increased tooth preparation. Quintessence Int., v. 27, n. 2, p. 115-21, Feb. 1996.

16- BURKE, F. J. T. Maximising the fracture resistance of dentine-bonded all-ceramic crowns. J. Dent. , v. 27, n. 3 , p. 169-73, Mar. 1999.

17- BURKE, F. J. T. ; QUALTROUGH, A. J. E. Aesthetic inlays: composite or ceramic? Brit. dent. J. , v. 176, n. 1, p. 53-60, Jan. 1994.

18- BURKE, F. J. T. ; WATTS, D. C. Fracture resistance of teeth restored with dentin-bonded crowns. Quintessence Int., v. 25, n. 5, p. 335-40, May 1994.

19- BURKE, F.J.T. ; WATTS, D. C. Effect of differing resin luting systems on fracture resistance of teeth restored with dentin-bonded crowns.

Quintessence Int. , v. 29, n.1, p. 21-7, Jan. 1998.

20- BURKE, F.J. T. ; WATTS, D. C. ; WILSON, N.H.F. Effect of cuspal coverage on fracture resistance of teeth restored with composite inlays. J. dent. Res., v. 70, p. 701, 1991. Special issue. / Abstract n. 264/

21- BURKE, F. J. T. ; WILSON, N. H. F. ; WATTS, D. C. The effect of cavity wall taper on fracture resistance of teeth restored with resin composite inlays. Oper. Dent., v. 18, n. 6, p. 230-6, Nov./Dec.1993.

22- CALAMIA, J. R.; VAIDYANATHAN, J.; VAIDYANATHAN, T. K. Shear bond strenght of etched porcelains. J. dent. Res. , v. 64, p. 296, 1989. Special issue. / Abstract n. 1096/ 
23- CAMERON, C. E. The cracked tooth syndrome: additional findings. J. Amer. dent. Ass., v. 93, n. 5, p. 971-75, May 1976.

24- CARVALHO, R. M. Adesivos dentinários. Fundamentos para aplicação clínica. Rev. Dent. Rest., v. 1, n. 2, p. 62-96, abr./jun. 1998.

25- CARVALHO, R. M. et al. A review of polymerization contraction: the influence of stress development versus stress relief. Oper. Dent., v. 21, n. 1, p. 1724, Jan./Feb. 1996.

26- CAVEL, W. T. ; KELSEY, W. P. ; BLANKENAU, R. J. An in vivo study of cuspal fracture. J. prosth. Dent., v. 53, n. 1, p. 38-42, Jan. 1985.

27- CHAIN, M. C.; BARATIERI, L. N. Restaurações adesivas diretas em dentes posteriores. In: Restaurações estéticas com resina composta em dentes posteriores. São Paulo. Artes Médicas, 1998. Cap. 4 , p.47-129.

28- CRAIG, R. G.; O’BRIEN, W. J. ; POWERS, J. M. Dental materials and their selection. 2.ed. Illinois, Quintessence, 1997.

29- CRISPIN, B. J. et al. Contemporary esthetic dentistry: practice fundamentals. Tokio, Quintessence , 1994.

30- DENEHY, G. E. ; TORNEY, D. L. Internal enamel reinforcement through micromechanical bonding. J. prosth. Dent., v. 36, n.2, p. 171-5, Aug. 1976.

31- DIETSCHI, D.; SPREAFICO, R. Restaurações adesivas. Conceitos atuais para o tratamento estético de dentes posteriores. Chicago, Quintessence, 1997. 
32- DIETSCHI, D. et al. In vitro resistance to fracture of porcelain inlays bonded to tooth. Quintessence Int., v. 21, n.10, p. 823-31, Oct. 1990.

33- EAKLE, W. S. Fracture resistance of teeth restored with class II bonded composite resin. J. dent. Res., v. 65, n.2, p. 149-53, Feb. 1986.

34- EAKLE, W. S. Increased fracture resistance of teeth: comparison of five bonded composite resin systems. Quintessence Int. , v. 17, n. 1, p. 17-20, Jan. 1986.

35- EAKLE, W. S. ; MAXWELL, E. H. ; BRALY, B. V. Fractures of posterior teeth in adults. J. Amer. dent. Ass., v. 112, n.2, p. 215-8, Feb. 1986.

36- EICK, J.D.; WELCH, F. H. Polimerization shrinkage of posterior composite resins and its possible influence on postoperative sensitivity. Quintessence Int., v.17, n.2, p.103-11, Feb. 1986.

37- EL-SHERIF, M. H. Fracture strenght of premolars with class 2 silver amalgam restorations. Oper. Dent., v. 13, n. 2, p. 50-3, Spring 1988.

38- FAIRHURST, C. W. Dental ceramics: the state of the science. Adv. dent. Res., v. 6, p. 78-81, Sept. 1992.

39- FAHL JUNIOR, N.; CASELLINI, R. C. Ceromer/FRC technology: the future of biofunctional adhesive aesthetic dentistry. Signature, v. 4, n. 2, p. 7-13, Summer 1997.

40- FILTEK Z250. Restaurador universal para dentes anteriores e posteriores: perfil técnico do produto. Saint Paul, 3M, 1998. 
41- FERRARI, M.; GORACCI, G.; GARCIA-GODOY, F. Bonding mechanism of three "one" systems to conditioned and unconditioned enamel and dentin. Amer. J. Dent., v. 10, n. 5, p. 225-30, Oct. 1997.

42- FREIBERG, R. S. ; FERRACANE, J. L. Evaluation of cure, properties and wear resistance of Artglass dental composite. Amer. J. Dent. , v. 11, n. 5, p. 214-8, Oct. 1998.

43- GALAN JUNIOR, J. Contribuição ao estudo das principais dimensões dos dentes humanos permanentes, de leucodermas brasileiros, em ambos os sexos. Rev. bras. odont., v. 27, n. 163, p. 145-58, maio/jun. 1970.

44- GARBER, D. A.; GOSDSTEIN, R. E. Porcelain and composite inlays and onlays: esthetic posterior restorations. Chicago, Quintessence, 1994.

45- GARONE NETTO, N.; BURGER, R.C. Inlay e onlay em dentística: cimentações adesivas com cimentos resinosos. In: TODESCAN, F.F.; BOTTINO, M. A. Atualização na clínica odontológica: a prática da clínica geral. São Paulo, Artes Médicas, 1996. p.161-90.

46- GELB, M. N. ; BAROUCH, E. ; SIMONSEN, R. J. Resistance to cusp fracture in class II prepared and restored premolars. J. prosth. Dent., v. 55, n.2, p. 184-5, Feb. 1986.

47- GOEL, V.K,; KHERA, S.C.; SING, K. Clinical implications of the response of enamel and dentin to masticatory loads. J. prosth. Dent., v. 64, n.4, p. 446-54, Oct. 1990.

48- GRACIS, S. E. et al. Shock-absorbing behavior of five restorative materials used on implants. Int. J. Prosthodont., v. 4, n. 3, p. 282-91, May/June 1991. 
49- GREGORY, W. A. et al. Physical properties and repair bond strength of direct and indirect composite resins. J. prosth. Dent., v. 68, n. 3, p. 406-11, Sept. 1992

50- HELKIMO, E. ; INGERVALL, B. Bite force and functional state of the masticatory system in young men. Swed. dent. J., v. 2, n.5, p. 167-75, 1978.

51- HIRASAWA, T. Initial dimensional change of composites in dry and wet conditions. J. dent. Res., v. 62, n. 1, p. 28-31, Jan. 1983.

52- HOGLUND, C.; VAN DIJKEN, J.; OLOFSSON, A. L. A clinical evaluation of adhesively luted ceramic inlays. A two year follow-up study. Swed. dent. J., v. 16, n. 4, p. 169-71, 1992.

53- HÖLAND, W.; FRANK, M. Material science of Empress glass-ceramics Ivoclar-Vivadent Report, n. 10, p. 3- 8, July 1994.

54- HOOD, J. A. A. Biomechanics of the intact, prepared and restored tooth: some clinical implications. Int. dent. J., v. 41, n. 1, p. 25-32, Feb. 1991.

55- HUMMEL, S. K. et al. Surface treatment of indirect resin composite surfaces before cementation. J. prosth. Dent., v. 77, n. 6, p. 568-572, June 1997.

56- INGRAHAM, R. The application of sound biomechanical principles in design of inlay , amalgam and gold foil restorations. J. Amer. dent. Ass. , v.40, n.4, p. 402-13, Apr. 1950.

57- JAGADISH, S. ; YOGESH, B. G. Fracture resistance of teeth with class 2 silver amalgam, posterior composite, and glass cermet restorations. Oper. Dent., v. 15, n.2, p. 42-7, Mar. / Apr. 1990. 
58- JENSEN, M. E. et al. Posterior etched-porcelain restorations: an in vitro study. Compend. Contin. Educ. Dent., v. 8, n.8, p. 615-22, Sept. 1987.

59- JOYNT, R. B. et al. Effects of composite restorations on resistance to cuspal fracture in posterior teeth. J. prosth. Dent., v. 57, n. 4, p. 431-5, Apr. 1987.

60- KANCA, J. Resin bonding to wet substrate. I. Bonding to dentin.

Quintessence Int., v. 23, n. 1, p. 39-41, Jan. 1992.

61- LAMBRECHTS, P. et al. Classification and potencial of composite luting materials. International Symposium on Computer Restorations. p.6190. May. 1991.

62- LANDY, N. A. ; SIMONSEN, R. J. Cusp fracture strength in class II composite resin restorations. J. dent. Res., v. 63, p. 175, 1984. Special issue. / Abstract n. 40 /

63- LARSON, T. D.; DOUGLAS, W. H.; GEISTFELD, R. E. Effect of prepared cavities on the strength of teeth. Oper. Dent. ,v. 6, n.1, p. 2-5, 1981.

64- LATTA, M. A.; BARKMEIER, W. Bond strength of a resin cement to a cured composite inlay material. J. prosth. Dent., v. 72, n. 2, p. 189 -93, Aug. 1994.

65- LEINFELDER, K. F. New developments in resin restorative systems. J. Amer. dent. Ass. , v. 128, n. 5, p. 573-81, May 1997.

66- LIBERMAN, R. et al. The effect of posterior composite restorations on the resistance of cavity walls to vertically applied occlusal loads. J. Oral Rehab., v. 17, n. 1, p. 99- 105, Jan. 1990. 
67- LOPES, L. M. P.; LEITAO, J. G. M.; DOUGLAS, W. H. Effect of a new resin inlay/onlay restorative material on cuspal reinforcement. Quintessence Int., v. 22, n. 8, p. 641-5, Aug. 1991.

68- LÖSCHE, G. M. Marginal adaptation of class II composite fillings: guided polymerization vs reduced light intensity. J. Adh. Dent., v. 1, n. 1, p. 319, Jan. 1999.

69- MACKENZIE, D. F. The reinforcing effect of mesio-occlusodistal acid-etch composite restorations on weakened posterior teeth. Brit. dent. J., v. 161, n. 11, p. 410-4, Dec. 1986.

70- MAK, M.; QUALTROUGH, A. J. E. ; BURKE, F. J. T. The effect of different ceramic materials on the fracture resistance of dentin-bonded crowns. Quintessence Int. , v. 28, n. 3, p. 197-203, Mar. 1997.

71- MCCULLOCK, A. J. ; SMITH, B. G. N. In vivo studies of cusp reinforcement with adhesive restorative material. Brit. dent. J., v. 161, n.12, p. 450-2, Dec. 1986.

72- MCINNES-LEDOUX, P.M.; LEDOUX, W. R.; WEINBERG, R. A bond strength study of luted castable ceramic restorations. J. dent. Res., v. 68, n. 5, p. 823-5, May 1989.

73- MISHELL, Y. ; SHARE, J. ; NATANSON, D. Fracture resistance of cl. II amalgam vs. light activated composite restorations. In vitro. J. dent. Res. , v. 63, p. 293, 1984. Special issue./ Abstract n. 1099/

74- MONDELLI, J. et al. Fracture strength of human teeth with cavity preparations. J. prosth. Dent., v. 43, n. 4, p. 419-22, Apr. 1980. 
75- MONDELLI, J. et al. Dentística. Procedimentos pré-clínicos. São Paulo, Ed. Premier, 1998.

76- MONDELLI, R. F. et al. Fracture strength of weakened human premolars restored with amalgam with and without cusp coverage. Amer. J. Dent. , v. 11, n. 4, p. 181-4, Aug. 1998.

77- MORIN, D. ; DELONG, R. ; DOUGLAS, W. H. Cusp reinforcement by the acidetch technique. J. dent. Res., v. 63, n. 8, p. 1075-8, Aug. 1984.

78- NAGEM FILHO, H. Materiais dentários: resina composta. 2.ed. Bauru, Produções Artes Gráficas, 2000.

79- NAKABAYASHI, N.; KOJIMA, K.; MASUHARA, E. The promotion of adhesion by the infiltration of monomers into tooth substrates. J. Biomed. Mater. Res., v. 16, n. 3, p. 265-73, May 1982.

80- NAKABAYASHI, N. ; WATANABE, A. ; GENDUSA, N. J. Dentin adhesion of "modified" 4 meta/mma-ttb resin: funcion of hema. Dent. Mat., v. 8, n. 4, p. 259-64, July 1992.

81- NAVARRO, M.F.L. Resistência à fratura de dentes extraídos e cariados, com preparos e restaurações. Estomat. Cult., v. 13, n.1, p. 56-60, jan./ jun. 1983.

82- OLIVA, R. A.; LOWE, J. A. Dimensional stability of composite used as a core material. J. prosth. Dent., v. 56, n. 5, p. 554-61, Nov. 1986.

83- OLIVEIRA, A. A. de. Estudo comparativo da resistência à fratura de dentes restaurados com restaurações parciais indiretas de polímero de vidro, resina composta e cerâmica. São Paulo, 1998. 98p. Dissertação (Mestrado) - Faculdade de Odontologia. Universidade de São Paulo. 
84- ÖZDEN, A. N. ; AKALTAN, F.; GÜLSEN, C. Effect of surface treatments of porcelain on the shear bond strength of applied dual-cured cement. J. prosth. Dent. , v. 72, n. 1, p. 85-8, July 1994.

85- PASCOTTO, R. C. Avaliação da infiltração marginal em nível de esmalte e cemento em cavidades de classe II mod restauradas com resina composta pela técnica incremental direta e com incrustrações de resina composta e de porcelana. Bauru, 1991. 142p. Dissertação (Mestrado) - Faculdade de Odontologia de Bauru, Universidade de São Paulo.

86- PASHLEY, D. H. et al. Adhesion testing of dentin bonding agents: a review. Dent. Mat., v. 11, n. 2, p. 117-26, Mar. 1995.

87- PEGORARO, C. N. Efeito de sistemas adesivos na resistência à fratura de pré-molares superiores humanos restaurados com amálgama. Bauru. 1996. 175p. Dissertação (Mestrado) - Faculdade de Odontologia de Bauru, Universidade de São Paulo.

88- PEREIRA, J. C. et al. Resistência à fratura de dentes molares superiores submetidos a diversos tipos de preparação cavitária. Estomat. Cult., v. 13, n. 2, p. 20-4, jul./dez. 1983.

89- PEUTZFELDT, A.; ASMUSSEN, E. Mechanical properties of three composite resins for the inlay/onlay technique. J. prosth. Dent., v.66, n.3, p. 32224, Sept.1991.

90- PILO, R. ; BROSH, T. ; CHWEIDAN, H. Cusp reinforcement by bonding of amalgam restorations. J. Dent., v.26, n. 5-6, p. 467-72, July/Aug. 1998. 
91- RASMUSSEN, S. T. et al. Fracture properties of human enamel and dentin. J. dent. Res., v. 55, n.1, p. 154-64, Jan./ Feb. 1976.

92- REEL, D. C. ; MITCHELL, R. J. Fracture resistance of teeth restored with class II composite restorations. J. prosth. Dent. , v. 61, n. 2, p. 177-80, Feb. 1989.

93- RETIEF, D. H. Standardizing laboratory adhesion tests. Amer. J. Dent. , v. 4, n. 5, p. 231-6, Oct. 1991.

94- SALIS, S. G. et al. Impact-fracture energy of human premolar teeth. J. prosth. Dent. , v. 58, n. 1, p. 43-8, July 1987.

95- SANTOS, A. C.; MEIERS, J. C. Fracture resistance of premolars with MOD amalgam restorations lined with amalgambond. Oper. Dent. , v. 19, n. 1, p. 2-6, Jan./ Feb. 1994.

96- SENE, F. Análise comparativa da quantidade de estrutura dentária removida em preparos cavitários para restaurações diretas e indiretas e a relação com a resistência à fratura do remanescente. Bauru. 2000. 120p. Dissertação (Mestrado) - Faculdade de Odontologia de Bauru, Universidade de São Paulo.

97- SHARE, J. ; MISHELL, Y. ; NATHANSON, D. Effect of restorative material on resistance to fracture of tooth structure in vitro. J. dent. Res., v. 61, p. 247, 1982. Special issue. / Abstract n. 622/

98- SHETH, J. J. ; FULLER, J. L. ; JENSEN, M. E. Cuspal deformation and fracture resistance of teeth with dentin adhesives and composites. J. prosth. Dent., v. 60, n. 5, p. 560-9, Nov. 1988. 
99- SHILLINGBURG, JUNIOR., H. T. Fundamentos dos preparos dentários para restaurações metálicas e de porcelana. 2.ed. São Paulo, Quintessence, 1991.

100- SHORTALL, A. C. ; BAYLIS, R. L.; WILSON, H. J. Composite inlay/luting resin bond strength surface treatment effects. J. Dent., v. 24, n. $1 / 2$, p. 129-35, Jan./Mar. 1996.

101- SILVA E SOUZA JÚNIOR, M. H. Procedimentos restauradores estéticos em resina e porcelana para dentes posteriores. Rev. Dent. Rest. , v. 1, n.1, p. 1-68, jan./mar. 1998.

102- SIMONSEN, R. J. ; LANDY, N. A. Preventive resin restorations: fracture resistance and 7-year clinical results. J. dent. Res., v. 63, p. 175, 1984. Special issue. / Abstract n. 39 /

103- SNYDER, D. E. The cracked-tooth syndrome and fractured posterior cusp. Oral Surg. , v. 41, n. 6, p. 698-704, June 1976.

104- STAMPALIA, L. L. et al. Fracture resistance of teeth with resin-bonded restorations. J. prosth. Dent., v. 55, n. 6, p. 694-8, June 1986.

105- STOKES, A. N.; TAY, W. M.; PEREIRA, B. P. Shear bond of resin cement to post-cured hybrid composites. Dent. Mat., v. 9, n. 6, p. 370-4, Nov. 1993.

106- SULIMAN, A. A. ; BOYER, D. B. ; LAKES, R. S. Cusp movement in premolars resulting from composite polymerization shrinkage. Dent. Mat., v. 9, n. 1, p. 6-10, Jan. 1993.

107- SWIFT JUNIOR, E. J. et al. Treatment of composite surfaces for indirect bonding. Dent. Mat., v. 8, n. 3, p. 193-6, May 1992. 
108- TOUATI, B. The evolution of aesthetic restorative materials for inlay and onlays: a review. Pract. Period. Aesth. Dent., v.8, n.7, p. 657-66, Sept., 1996.

109- 3M Dental Products Laboratory. RELY X ARC Adhesive resin cement system: technical product profile. Saint Paul MN, 3M, 1998.

110- VALE, W. A. Cavity preparation. Irish Dent. Rev., v. 2. p. 33-41, 1956.

111- VALE, W. A. Cavity preparation and further thoughts on high speed. Brit. dent. J. , v. 107, n.11, p. 333-46, Dec. 1959.

112-VARGA, J.; MATSUMURA, H.; MASUHARA, E. Bonding of amalgam filling to tooth cavity with adhesive resin. Dent. Mat., v. 5, n. 2, p. 158-64, Dec.1986.

113- YOSHIKAWA, T. et al. Effects of dentin depth and cavity configuration on bond strength. J. dent. Res., v. 78, n. 4, p. 898-905, Apr. 1999.

114- WATTS, D. C. ; WILSON, N. H. F. ; BURKE, F. J.T. Indirect composite preparation width and depth and tooth fracture resistance. Amer. J. Dent. , v.8, n. 1, p. 15-9, Feb. 1995.

115-WENDT, S. L. The effect of heat as a secondary cure upon the physical properties of three composite resins. II Wear, hardness and color stability. Quintessence Int., v.18, n. 5, p. 351-6, May 1987.

116- WENDT, S. L. ; LEINFELDER, K. F. The clinical evaluation of heat-treated composite resin inlays. J. Amer. dent. Ass., v. 120, n. 2, 177-81, Feb.1990. 
117- WIECZKOWSKI JUNIOR, G. et al. Effects of incremental versus bulk fill technique on resistance to cuspal fracture of teeth restored with posterior composites. J. prosth. Dent., v. 60, n. 3, p. 283-7, Sept. 1988.

118- WIECZKOWSKI JUNIOR, G. et al. Effects of storage in formalin on dentinal bond strength. J. dent. Res. , v. 68, n. 1, p. 344, Mar. 1989. Special issue. / Abstract n. 1298 /

119- WILLEMS, G. Three year follow-up of five posterior composites: in vivo wear. J. Dent., v.21, n.2, p. 74-8, Apr. 1993.

120- ZARDIACKAS, L. D. ; STONER, G. E. Tensile and shear adhesion of amalgam to tooth structure using selective interfacial amalgamation. Biomaterials, v. 4, n.1, p. 9-13, Jan. 1983. 
ABSTRACT 


\section{ABSTRACT}

\section{Fracture resistance of adhesively restored teeth with composite resin and ceramic restorations.}

The purpose of this study was to evaluate the fracture resistance of teeth restored with direct and indirect restorations of composite resin and restored with indirect ceramic restorations. Fifty-six maxillary premolar teeth were selected and divided at random into seven groups; Group 1 (control): intact teeth; Group 2: MOD cavity preparations, $1 / 2$ intercuspal distance, with rounded internal angles, convergent walls, unrestored; Group 3: MOD cavity preparations, 1/2 intercuspal distance, divergent walls; Group 4: same preparation as group 2, restored with direct composite resin (Single Bond/ Filtek Z250); Group 5: same as group 3, restored with indirect composite resin (Artglass-Kulzer/Single Bond/ Rely X); Group 6: same as group 3, restored with indirect composite resin (Targis-Ivoclar/ Single Bond/ Rely X); Group 7: same as group 3, restored with indirect ceramic restoration (IPS Empress Ivoclar/ Single Bond/Rely X). The specimens were subject to a compressive axial load in a Universal testing machine at $0.5 \mathrm{~mm} / \mathrm{min}$ by means of a steel bar $(8 \mathrm{~mm}$ in diameter). The mean fracture strength obtained was (kgf): Group 1: 193,93 $\pm 24,46$;

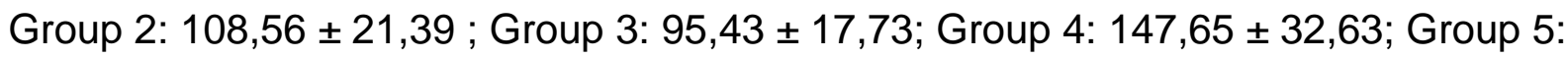
184,15 \pm 56,49; Group 6: 183,81 \pm 31,95; Group 7: 181,12 \pm 40,49. There were no significant $(p<0.05)$ differences between intact teeth and teeth restored with indirect restorations. These results suggest that prepared teeth were significantly weaker than control group; teeth restored with direct and indirect composite resins were significantly more resistance to fracture than were similarly prepared but unrestored 
teeth. Restoring teeth with direct composite restoration increased the fracture resistance in relation to the control group, but was unable to strengthen them compared with unrestored teeth. These results showed that a bonded indirect restoration could be an ideal option for restoring teeth weakened by wide cavity preparation. 